Florida International University FIU Digital Commons

$7-1-2013$

\title{
Post-Revolutionary Post-Modernism: Central American Detective Fiction by the Turn of the 21st Century
}

Gael Guzman-Medrano

Florida International University, gael2975@gmail.com

DOI: $10.25148 /$ etd.FI13080707

Follow this and additional works at: https://digitalcommons.fiu.edu/etd

Part of the Latin American History Commons, Latin American Languages and Societies Commons, Latin American Literature Commons, $\underline{\text { Modern Literature Commons, and the Spanish }}$ Literature Commons

\section{Recommended Citation}

Guzman-Medrano, Gael, "Post-Revolutionary Post-Modernism: Central American Detective Fiction by the Turn of the 21st Century" (2013). FIU Electronic Theses and Dissertations. 917.

https://digitalcommons.fiu.edu/etd/917 


\title{
FLORIDA INTERNATIONAL UNIVERSITY
}

Miami, Florida

\section{POST-REVOLUTIONARY POST-MODERNISM: CENTRAL AMERICAN} DETECTIVE FICTION BY THE TURN OF THE $21^{\text {ST }}$ CENTURY

\author{
A dissertation submitted in partial fulfillment of \\ the requirements for the degree of \\ DOCTOR OF PHILOSOPHY \\ in \\ SPANISH \\ by
}

Gael Guzman-Medrano 
To: Dean Kenneth G. Furton

College of Arts and Sciences

This dissertation, written by Gael Guzman-Medrano, and entitled Post-revolutionary Post-modernism: Central American Detective Fiction by the Turn of the $21^{\text {st }}$ Century, having been approved in respect to style and intellectual content, is referred to you for judgment.

We have read this dissertation and recommend that it be approved.

$\begin{array}{r}\hline \text { Maida Watson } \\ \hline \text { Maria Asuncion Gomez } \\ \hline \text { Santriago Juan-Navarro, Major Professoras }\end{array}$

Date of Defense: July 1, 2013

The dissertation of Gael Guzman-Medrano is approved.

$\begin{array}{r}\begin{array}{r}\text { Dean Kenneth G. Furton } \\ \text { College of Arts and Sciences }\end{array} \\ \hline \begin{array}{r}\text { Dean Lakshmi N. Reddi } \\ \text { University Graduate School }\end{array}\end{array}$

Florida International University, 2013 


\section{DEDICATION}

To my family and Max. 


\section{ACKNOWLEDGMENTS}

I wish to thank the members of my committee for their support, patients and guidance. I would like to recognize Dr. Maida Watson's perceptive and insightful reading of the manuscript, and for her genuine concern for my success and that of the rest of her students. I truly enjoyed our conversations on Panamanian literature and cultural expressions. I also want to thank Dr. Maria Asuncion Gomez who is an outstanding educator and demonstrates in and out of the classroom a high level of commitment to her students. Her valuable feedback and directions during my career as a student at FIU helped me reach many goals. I also want to express my gratitude to Dr. Astrid Arraras whose amiable smile and committed support to this project as an outside reader made this dream a reality. Her approachable demeanor and knowledge make her a great educator. Finally, I am extremely and forever grateful to my Major Professor Dr. Santiago JuanNavarro. I am honor to have had the guidance and support of a great scholar and dedicated mentor. His knowledge and passion on postmodernism opened a new field of investigation for me. Thank you for always believing in me and never leaving my side. My gratitude also goes to my dear friend and classmate Elizabeth Solis for her continuing friendship and support through the many experiences we shared during our trajectory as graduate students. 


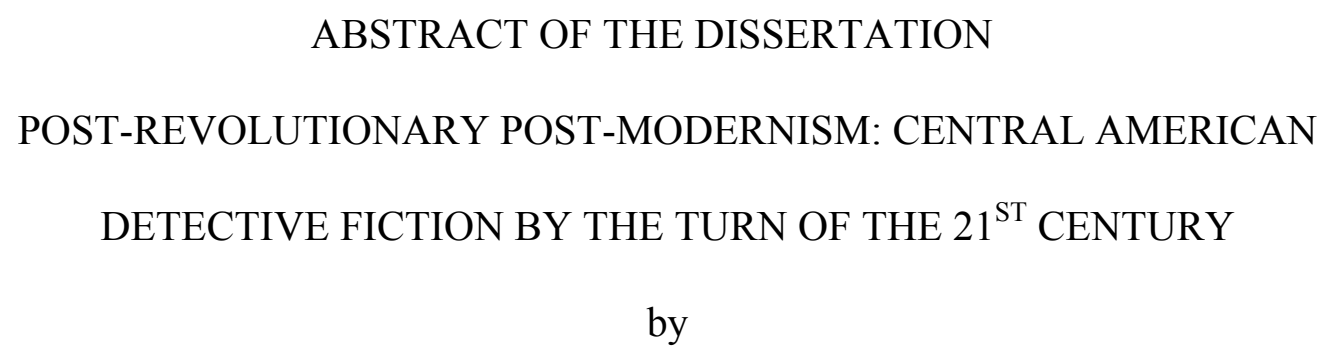

Gael Guzman-Medrano

Florida International University, 2013

Miami, Florida

Professor Santiago Juan-Navarro, Major Professor

Contemporary Central American fiction has become a vital project of revision of the tragic events and the social conditions in the recent history of the countries from which they emerge. The literary projects of Sergio Ramirez (Nicaragua), Dante Liano (Guatemala), Horacio Castellanos Moya (El Salvador), and Ramon Fonseca Mora (Panama), are representative of the latest trends in Central American narrative. These trends conform to a new literary paradigm that consists of an amalgam of styles and discourses, which combine the testimonial, the historical, and the political with the mystery and suspense of noir thrillers. Contemporary Central American noir narrative depicts the persistent war against social injustice, violence, criminal activities, as well as the new technological advances and economic challenges of the post-war neo-liberal order that still prevails throughout the region.

Drawing on postmodernism theory proposed by Ihab Hassan, Linda Hutcheon and Brian MacHale, I argued that the new Central American literary paradigm exemplified by Sergio Ramirez's El cielo llora por mí, Dante Liano's El hombre de Montserrat, Horacio Castellanos Moya's El arma en el hombre and La diabla en el espejo, and Ramon Fonseca 
Mora's El desenterrador, are highly structured novels that display the characteristic marks of postmodern cultural expression through their ambivalence, which results from the coexistence of multiple styles and conflicting ideologies and narrative trends. The novels analyzed in this dissertation make use of a noir sensitivity in which corruption, decay and disillusionment are at their core to portray the events that shaped the modern history of the countries from which they emerge. The revolutionary armed struggle, the state of terror imposed by military regimes and the fight against drug trafficking and organized crime, are among the major themes of these contemporary works of fiction, which I have categorized as perfect examples of the post-revolutionary post-modernism Central American detective fiction at the turn of the 21 st century. 


\section{TABLE OF CONTENTS}

CHAPTER

PAGE

INTRODUCTION

I. THE NOIR NARRATIVE IN CENTRAL AMERICAN LETTERS

I.1. A Brief Historical Background of the Detective Fiction

I.2. Multiple Definitions of the Noir Narrative

I.3. Typifying Characteristics of the Classic Detective and the Noir Narratives

I.3.1. Typifying Characteristics of the Noir Narrative

I.3.2. Summary of the Main Characteristics of the Classic

Detective Novel and the Noir Novel

I.4. What Then Constitutes the Noir Narrative?

I.5. The Noir Genre in Latin America

I.6. The Birth of the Central American Noir Narrative

I.7. Historical Contextualization of the Central American

Noir Narrative

I.8. Central American Noir Narrative, An Expression of Postmodernity

I.9. An Overview of Postmodernism

II. SERGIO RAMIREZ'S EL CIELO LLORA POR MÍ:

(RE)INVENTING FACTS-CONSTRUCTING

"HISTORIOGRAPHICAL" NOIR FICTION

II.1. History in Sergio Ramirez's Literary Project

II.2. Sergio Ramirez's Literary Postmodernity

II.3. El cielo llora por mí: An Introduction

II.4. The (Re)construction of the Narrative Space in

Ramirez's Novel

II.4.1. Fact and Fiction in El cielo llora por mí

II.4.2. Heteroglossia in El cielo llora por mí

II. 4.2.1. The Contemporary and Prevailing Literary Discourse

II. 4.2.2. The Historiographic Discourse in El cielo llora por mí

II. 4.2.3. The Socio-Cultural Discourse in El cielo llora por mí

II. 4.2.4. Other Discoursive Forms in El cielo llora por mí

II.4.3. Other Postmodern Structural Aspects of El cielo llora por mí

II. 4.3.1. El cielo llora por mí, the Noir Narrative and Postmodernity

II. 4.3.2. Referenciality, a Postmodern Element in El cielo llora por mí

II.5. Conclusion

III. THE CENTRAL AMERICAN LITERARY TRADITION

OF VIOLENCE IN DANTE LIANO'S AND HORACIO

CASTELLANO MOYA'S NARRATIVE PRODUCTION 
III.1. Violence in Central American Letters

III.2. History and Reflexivity in Dante Liano's Literary Project

III.3. Dante Liano's Literary Postmodernity

III.3.1. El hombre de Montserrat: Plot, Main Character and

Other Relative Information of Liano's Novel

III.3.2. Technical Practices in the (Re)construction of

Reality in the Narrative Space in Liano's novel

III.3.3. The Theme of Violence in El Hombre de Montserrat

III.3.4. El Hombre de Montserrat as a Postmodern Parody

of the Detective Narrative

III.3.5. Other Characters in El Hombre de Montserrat

III.4. Horacio Castellanos Moya's Literary Project

III.5. Literary Postmodernity in Castellanos Moya's Narrative

III.5.1. Corruption in Castellanos Moya's La diabla en el espejo

and El arma en el hombre

III.5.2. Violence in Castellanos Moya's La diabla en el espejo

and El arma en el hombre

III.5.3. Aspects of the Noir Narrative in La diabla en el espejo

and El arma en el hombre

III.6. Conclusion

IV. THE CENTRAL AMERICAN LITERARY TRADITION

OF PATRIOTISM IN RAMON FOSECA MORA'S

EL DESENTERRADOR

IV.1. Ramon Fonseca Mora's Literary Project

IV.2. Ramon Fonseca Mora's Literary Postmodernity

IV.3. El Desenterrador: An Overview

IV.4. Elements of the Noir Narrative Tradition in El desenterrador

IV.5. Postmodern Practices: The (Re)construction of Reality in

Fonseca Mora's novel El desenterrador

IV.5.1. Heteroglossia in El desenterrador

IV.5.2. The Historiographic Discourse in El desenterrador

IV.5.3. A Parody of the Testimonial Account in El desenterrador

IV.5.4. The Socio-Cultural and Political Discourse in El desenterrador

IV.5.5. Other Postmodern Structural Aspects of El desenterrador

IV. 6. Conclusion

CONCLUSION

BIBLIOGRAPHY

VITA 


\section{INTRODUCTION}

Contemporary Central American literature has been popularized by the political armed struggle that occurred during the last four decades of the $20^{\text {th }}$ century. In the late 1960s and through the first half of the 1980s, Central America came to be known as a region filled with violent guerrillas and heartbreaking civil wars. In the United States and in Europe, the focus of the criticism of Central American literature was on explaining how the literature of the region became an instrument of resistance and political struggle. The use of testimonial discourse in poetry and narrative became the instrument to transfer to the literary space the violent wars against social injustice. Hector Leyva has noted that in the Central American literature produced during this historical period the element of violence is a constant in the three most representative literary tendencies that characterize this epoch: the novel written by guerrilla members, the testimonial narrative written by civilians affected by the armed struggles and the novels written by political dissidents; thus, this literary paradigm foregrounds the testimonial narrative (19). Since the Cuban Revolution, Central American literature - the narrative in particular - has privileged the testimonial discourse, especially when it dealt with the relationship between history/reconstruction of memory and literature.

The socio-political changes that occurred in late 1980s and through the 1990s (i.e. the end of the civil wars and the signing of peace treaties and of international free trade agreements) in the region brought a change in the literary paradigm and the testimonial account is no longer at the center of the literary production. The testimonial account has lost its primordial characteristic of being a discourse very close to factual accounts 
narrated by those who witness them. The German critic Werner Mackenbach has noted that this change of paradigm in Central American letters went from a politically committed literature that denounced the social injustice that prevailed in the region to a more aesthetic narrative. The new literary trend exhibits a fragmented and more experimental narrative in which the historical past is incorporated (2008 68). In the new literary paradigm, the testimonial account has become a literary artifice by which fictional characters - inspired by historical figures — make reference to significant historical events. The testimonial account in the new literary form, instead of being used to evidence the human rights abuses and the violence and oppressions of the wars against the political regimes, is being used in a parodic form as a way to revisit the past in order to infer and comment on the present state of affairs in Central America. The construction of a parody of the testimonial narrative in the new Central American literary modality is one of the ways by which the narrative production of the region signals its incorporation of characteristics of postmodern cultural expression.

To talk about postmodernist Central American literature may appear to be an odd proposition, especially when one takes into account the controversy that the use of the term has caused in studies of Hispanic American postmodernity. The term postmodernism, used here to refer to the socio-historical reality and artistic production of Spanish-American countries, is an alien concept for many. This dissertation, which focuses on a body of literature that exhibits multiple aspects of the noir fiction written in Central America during the 1980s and 1990s attempts to demonstrate that this sort of contemporary fiction produced in the isthmus reflects many of the typifying characteristics of postmodern literary works, for they are characterized by many of the 
main components of postmodernist literature produced elsewhere. Through the combination of styles and discourses - like the testimonial account, the historical, the political, the mystery and the noir - and through the use of experimental writing techniques - like dialogism, multiperspectivism, and metatextuality - the five novels I analyze in my dissertation exhibit their postmodernism.

Drawing on postmodernism theory proposed by Ihab Hassan, Linda Hutcheon and Brian MacHale, I argue that the new Central American literary paradigm exemplified by Sergio Ramirez's El cielo llora por mí, Dante Liano's El hombre de Montserrat, Horacio Castellanos Moya's El arma en el hombre and La diabla en el espejo, and Ramon Fonseca Mora's El desenterrador, are highly structured novels that display the characteristic marks of postmodern cultural expression through their ambivalence, which results from the coexistence of multiple styles and conflicting ideologies and narrative trends. The novels analyzed in this dissertation make use of a noir sensitivity in which corruption, decay and disillusionment are at the core to portray the events that shaped the modern histories of the countries from which they emerge. The revolutionary armed struggle, the state of terror imposed by military regimes and the fight against drug trafficking and organized crime are among the major themes of these contemporary works of fiction. I have categorized this group of novels as perfect examples of the post-revolutionary post-modern Central American detective fiction at the turn of the 21 st century.

Chapter I of this dissertation presents an overview of the history of the noir novel as a direct descendent of the detective novel. I note how the detective narrative tradition in its long history has gone through various interpretations of which its most contemporary form is the noir narrative. In this chapter, I also summarize the popularity 
of the noir genre in Latin American letters since it first appeared. In addition, I devote part of the chapter to study how the consequences of the Nicaraguan, Salvadoran and Guatemalan civil wars of the 1970s and 1980s brought about a significant body of literature in the late 1980s and early 1990s that contextualizes the political struggles of the area and how this narrative production resembles the noir genre. Finally, in the last section of the chapter, I have made an attempt to summarize the rise of postmodernity in the contemporary cultural arena and its key features. My interest in this chapter is to observe how the long trajectory of noir fiction has aided contemporary Central American fiction writers to revise the testimonial by incorporating the themes of violence, corruption, decay and disillusionment as key components of their "fictionalization of reality." These writers are able to achieve this objective by the implementation of elements that typify the postmodern literary work such as the metafictional and historiographical elements in their noir narratives.

Chapter II investigates the specific conditions of the production of Sergio Ramirez's literary postmodernity as presented in his novel El cielo llora por mí. I intend to demonstrate how the Nicaraguan novelist invariably blurs elements of fact and fiction within his narrative to create a contrast between the previous Central American literary productions, characterized by the hope to promote social change through the solidarity and collective action of the poor through the taking of arms, and the new narrative form which foregrounds the individual desires, passions and struggle for survival in the new neo-capitalist economic system of the post-revolutionary period. I suggest that this blurring of fact and fiction creates a thoroughgoing skepticism that lacks any definitive sense of coherent certainty, all markers of postmodernity. I shall focus my discussion on 
some of the formal techniques and properties of Ramirez's novel and analyze how they parallel the techniques of postmodernist formal literature.

Chapter III of my work analyzes specific aspects of the presence of the element of violence in Central American contemporary literature as key component of this new body of literature. Violence has always been a constant element in Latin America's literary productions. Throughout the multiple phases of Latin America's literary history, writers have used literature as a vehicle to denounce violence — most specifically political violence. Historical fiction, testimonial narrative and politically committed poetry are but a few examples through which violence has come to be regarded as an aesthetic form in Latin American letters. Many writers took the concept of violence during the years of armed struggle in Central America as an instrument that helped exposed the political oppression of authoritarian governments and the military forces. In this chapter, I focus my analysis on how El hombre de Montserrat by Guatemalan writer Dante Liano and La diabla en el espejo and El arma en el hombre by Salvadoran writer Horacio Castellanos Moya make use of the noir sensibility and blend it with postmodern writing techniques in order to recreate dark violent periods of their countries' recent histories. Through their work, these two novelists denounce the abuses of the military forces and the criminal actions of many members of their societies.

Chapter IV examines how the elements of patriotism and cultural idiosyncrasy that prevail in Ramon Fonseca Mora's El desenterrador are combined with a series of experimental writing techniques that exhibit the novelist's tendency toward postmodern fiction writing. In this chapter, we analyze how this very ambitious novel incorporates many of the components of what constitutes postmodern narrative. We explore how the 
Panamanian writer through the combination of styles and discourses-like the testimonial account, the historical, the political, the mystery and the noir — and through the use of experimental writing techniques - like dialogism, multiperspectivism, and metatextuality — creates a certain representation of two historical moments that marked the recent history of the Central American nation.

Chapters II through IV — which are the textual analysis of the novels selected for my study — are outlined in a similar pattern. I begin each chapter by making a summary of the literary project of each of the four Central American authors and how their works exhibit an almost obsessive concern for (re)writing history by using writing techniques proposed by postmodernism. I proceed to make an overview of the novels where I put emphasis on highlighting specific structural characteristics of each of the novels and how the authors transfer the everyday reality of contemporary Central American societies to the fictional space by utilizing certain aspects of postmodern fiction writing. Thus, my method of inquiry combines a formal and contextual analysis that attempts to articulate how these novels do not fit neatly within the generic classification of the detective or noir narrative. The five novels analyzed in my dissertation allude to and play with the conventions of the detective literary tradition in a form of postmodern parody in order to depict the radical socio-political changes that the region suffered in the latter part of the twentieth century. 


\section{CHAPTER I}

\section{THE NOIR NARRATIVE IN CENTRAL AMERICAN LETTERS}

The noir narrative has a well-established history in Latin American literature. The genre appeared almost simultaneously soon after its debut in the United States during the first decades of the $20^{\text {th }}$ century, and since then it has been particularly prolific in countries such as Mexico, Chile and Argentina, where it includes a rich repertoire of characteristics. Nevertheless, it is important to establish that this form of fiction is not presented in the same way in all the literary productions of the region, and its production has not been so abundant in certain regions of Spanish-America. This is the case of the noir literature in the Central American region. In comparison to the editorial boom of this genre in Mexico, Chile and Argentina, it is only during the last decades of the 20th century that a significant number of noir narratives started to appear in the isthmus. Since the 1980s, Central American writers have produced a body of literature that exhibits aspects of the noir narrative that is not only significant because of its quantity, but also because of its quality. However, the typifying elements of this narrative have not been studied in great depth by critics, and have gotten very little recognition from the literary world elsewhere.

Until the appearance of a series of novels that incorporate the noir sensibility in the past three decades in Central America, the literature of the region was little known for the production of such type of fiction. A body of work incorporating many of the key elements of the noir narrative began to appear in the literary world only in the years following the political upheavals of the 1960s throughout the isthmus and the 
Nicaraguan, Salvadoran and Guatemalan revolutionary and civil wars of the 1970s and 1980s. Most of these literary works do not adhere in every sense to the paradigm of the noir narrative, but they incorporate many of the characteristics of the genre. Corruption, decay, and disillusionment are at the thematic core of this body of work. The new literary modality forms part of a larger Latin American editorial explosion of noir novels that has appeared since the 1980s. However, in the case of the Central American noir fiction, it is the result of the dramatic historical changes that occurred from the 1960s to the present day, and are often its principal theme. Novels such as El cielo llora por mí, by Nicaraguan writer Sergio Ramirez; El hombre de Montserrat ${ }_{2}$ by Guatemalan writer Dante Liano; La diabla en el espejo and El arma en el hombre, by Salvadorian writer Horacio Castellanos Moya; and El desenterrador, by Panamanian writer Ramón Fonseca Mora exemplify the unique characteristics of what can be classified as the contemporary Central American noir narrative. The analysis of these texts and of the social conditions under which they emerged will allow me to create a repertoire of specific traits that set apart Central American detective novels from the rest of Latin American noir genre.

Among one of the main characteristics of this new literary form — and very much present in the texts analyzed in this study - is the fact that these narrative bear witness to the reconstruction of memory by drawing attention to elements that were left unaccomplished by the political upheavals and post-revolutionary wars of the last four decades in the region. They attempt to track down the multiple signs of social changes that occurred before, during and after this period of political turmoil. This task is based on the writings of the most recent theories of postmodern fiction proposed by critics such as Ihab Hassan, Brian McHale and Linda Hutcheon. The analysis of this dissertation will 
focus on the strategies through which Sergio Ramirez, Dante Liano, Horacio Castellanos Moya and Ramón Fonseca Mora developed their novels by incorporating the themes of violence, corruption, decay and disillusionment as key components of their "fictionalization of reality" and through the implementation of metafictional and historiographical elements into the structure of these Central American noir novels.

The detective narrative from which the noir novel descends has a 200 -year-old tradition. The genre is a direct descendant of the Romantic literature of the 1800s. In its long history, the detective narrative has gone through various interpretations of which its most contemporary form is the noir narrative. In all of its forms, the detective narrative has reflected the social and literary trends. This is not to say that the same is not true of other literary genres, but this relationship is more readily observed in the detective narrative. Given that the detective fiction has a long and complex history, it seems useful to begin this study with an exploration of its trajectory in order to have a better understanding of the theoretical base of what constitutes the new Central American noir narrative. In section I. 1, I attempt to outline how the detective fiction developed from the classic detective fiction - a literary tradition inaugurated by Edgar Allan Poe and popularized by Sir Arthur Conan Doyle — to the "hard boiled" detective novel (a subgenre popularized by Raymond Chandler and Dashiell Hammett). Section I. 2 registers the definition of noir fiction given by experts in this narrative. In Section I. 3, I review the general typifying characteristics of the classical detective and noir genres, characteristics that not only gave these narratives their form but also earned them a reputation of being "less serious literature" by the literary critics. In section I. 4, I make a summary of what precisely constitutes a noir narrative. In section I. 5, Latin American noir narrative is 
briefly compared to American noir fiction. Sections I. 6 and I. 7 examine the birth of noir narrative in Central America. In section I. 8, I briefly outline how Central American noir narrative is an example of the postmodern thought. Finally, in section I.9, I have made an attempt to summarize the rise of postmodernity in the contemporary cultural arena and its key features. My interest in this chapter is to observe how the long trajectory of the noir fiction has aided contemporary Central American fiction writers to incorporate the new literary paradigm by incorporating the themes of violence, corruption, decay and disillusionment as key components of their "fictionalization of reality." These writers achieve this task by the implementation of elements that typify the postmodern literary work such as the metafictional and historiographical elements in their noir narratives.

\section{1. A Brief Historical Background of the Detective Fiction}

The noir narrative is the name given to a contemporary mode of crime/detective fiction that has a long history that can be traced back to the first half of the $19^{\text {th }}$ century, and its different version have echoed the social and literary trends of this period. The very first examples of crime/detective stories were born during the Romantic period and later evolved and incorporated characteristics of the Realist literature. This type of novel can be seen as a bridge that unites the gap between romantic and realist fiction. The noir narrative is the evolved version of two distinctive detective narratives: 1) what has come to be known as the "classical detective" fiction and 2) "the hardboiled" crime fiction. The "classical detective" story is characterized by a plot consisting of figuring out a puzzle. In order to resolve the mystery, it is essential to determine who is the murder despite the fact that he or she has vanished in thin air leaving a body lying on the floor of 
a closed chamber and not obvious clues. In this type of detective literature, someone has committed a crime and this is the enigma to be solved. The detective narrative I describe above is the type of detective story produced by Edgar Allan Poe who invented the detective fiction with the creation in 1841 of the character of Monsier Auguste Dupin in The Murders of Morgue Street. Sir Arthur Conan Doyle popularized this narrative with his famous detective character Sherlock Holmes. The second classification of detective story is the story of suspense - which is distinguished by the unsentimental portrayal of violence and sex. Dashiell Hammett with Red Harvest (1927) initiated this subgenre. This kind of narrative is characterized by the depiction of a very harsh reality. This type of detective novels incorporates elements of the everyday reality of the 1920s and 1930s in the United States. These stories portrait a corrupt society in which its members are in a constant struggle for survival.

The first type, which can be called the "novel of the enigma" or the "classic detective" novel, was convention filled and followed a set pattern in the development of the plot. When speaking of the detective novel, in which the enigma is at the core of the plot, one cannot overlook the work of Sir Arthur Conan Doyle (1859-1930), the Scottish doctor who invented the well-known detective Sherlock Holmes. Conan Doyle gained vast popularity with works such as Study in Scarlet (1887), The Sign of Four (1890), The Hound of the Baskervilles (1902) and many other novels and short stories. The detective narrative of Conan Doyle is filled with conventions and situations that seem extremely unreal. However, his greatest accomplishment is to have created the first detective hero to gain worldwide popularity. 
Sir Arthur Conan Doyle was heavily influenced by the work of Edgar Allan Poe, Émile Gaboriau and Jules Verne. His narrative can be easily classified in the adventure genre, and even though he gained worldwide recognition for his work, he always denigrated the genre that made him famous. Maria Elvira Bermudez in her prologue to the Porrua editon of Las aventuras de Sherlock Holmes (1982) states that Conan Doyle: “al parecer, no tuvo gran aprecio por su personaje más conocido. Dotó a Sherlock Holmes de cualidades excepcionales, pero también con defectos serios y siempre consideró sus obras policiales inferiores a las de índole histórica" (iv).

We must note that in such remark-from the individual who can be considered one of the pioneers of the detective genre-lays the foundation for the belittlement of the detective genre that prevailed throughout its history. Conan Doyle made an attempt to write historical, gothic and adventure novels, but the one at which he excelled was the one he felt was a genre of very little value. The adventures of Sherlock Holmes take place during the Victorian era when the theories of positivism and rationalism prevailed. Darwin and Spencer's theories transformed the catholic Conan Doyle into an agnostic and rationalist, personality traits also found in Sherlock Holmes who made use of the deductive method to solve the enigmatic cases that came before him. Any discussion of the classic detective narrative whose plot consisted of a puzzle which plot presented an enigma that can only be resolved by the power of a good rational mind, cannot take place without the mention of Sir Arthur Conan Doyle. For many, he is considered the father of the genre, and it is interesting to note that he can also be considered one of its most assiduous critics. 
From the closed chamber mystery plots of Poe and the enigmatic stories of Conan Doyle (the "classic" detective novel) to what later came to be known as the "hardboiled" crime fiction, there was a long path during which time this narrative came to be influenced by several other genres. However, before discussing the influence of other styles of writing on the evolution of the crime/detective novel, it becomes necessary to first define the second style of crime/detective fiction: "hardboiled" crime fiction. This style of detective narrative makes use of all the possibilities presented by the real world and is a good reflection of it. This narrative is particularly known for its crude portrayal of violence and sex. The term "hardboiled" detective comes from the colloquial phrase that refers to an egg that has been boiled to a point of being completely firm. Like the egg, the "hardboiled" detective is characterized by having a tough shell and exhibiting a tough attitude when facing danger and violence in the process of solving a mystery. Dashiell Hammett's character Sam Spade and Raymond Chandler's Philip Marlowe are the quintessential models for the "hardboiled" detective. In the United States, during the 1930s and 1940s, "hardboiled" crime fiction was emulated by a great number of writers, among them: Chester Himes, Mickey Spillane, Ross Macdonald, John D. MacDonald, Robert B. Parker, Sara Paretsky, Sue Grafton, and Walter Mosley.

Among the genres that made an impact in the evolved version of the crime/detective narrative the gothic or horror genre- the novels of Mary Shelley, Nathanael Hawthorne, Bram Stoker and Howard Phillip Lovecraft—must be the first to be mentioned. Another genre that heavily influenced the crime/detective fiction of the early decades of the $1900 \mathrm{~s}$ was the novel of adventure such as those written by Hermann Melville, Joseph Conrad, Jack London and John Dos Passos. A third kind of literature that left a mark in this 
narrative is the literature of the West, novels such as those produced by Francis Brett Harte, Ambrose Bierce and Zane Grey, among others. ${ }^{1}$ The "hardboiled" crime narrative took from its predecessors almost all the characteristics that define the genre: the suspense, the effect of anxiety and agitation that a good crime/detective narrative must provoke in the reader, the fast past rhythm of the narrative, the individual heroism of its protagonists, the intensity of the action and the violence. Dashiell Hammett, Raymond Chandler and a vast number of writers took these elements and added others such as the struggle between good and evil, a very intriguing argument, power hunger, ambition and corruption in order to establish the bases for the new evolved version of the crime/detective fiction that came to be known as "hardboiled" and that eventually lead to what we now refer to as the noir narrative.

\section{2. Multiple Definitions of the Noir Narrative}

Javier Coma in La novela negra defines the genre as:

... una literatura narrativa con origen en los Estados Unidos durante los años 20 y con desarrollo típica y primordialmente norteamericano, ceñida al enfoque realista y sociopolítico de la contemporánea temática del crimen, encausada paulatinamente como un genero determinado, y practicado mayoritariamente por especialistas (8).

\footnotetext{
${ }^{1}$ The influence of the narrative genre of the far West in the noir narrative can be established among other things by the action, the violence, the intrigue, the corruption, the social criticism and the individual heroism portrait by the protagonists in the plot of such novels. However, the most influential element of the Western in the noir is the realism that can be seen in the actions of the men and women that populated these novels. They were true depictions of men and women of flesh and bone that spoke and acted like the real protagonists of the conquest of the West.
} 
I stated previously, at the beginning of section I. 2, that the noir narrative is the name given to a contemporary mode of crime/detective fiction. The subgenre is the evolved crime/detective fiction of the "hardboiled" style. The popular use of the French adjective "noir" in the term "noir narrative" derives immediately from "film noir" as it has been used to characterize certain "dark" Hollywood crime dramas and melodramas, many of them based on the works of "hardboiled" writers. ${ }^{2}$ From its predecessor, the noir narrative retained all of the characteristics mentioned in the previous section, but exhibits new particularities. One very important distinguishing feature of the noir narrative is that the protagonist is usually not a detective, but instead it is a victim, a suspect or a perpetrator. He or she is an individual who in most cases is closely tied to the crime. He or she is not necessarily an outsider called to solve a crime. Other common characteristics are the emphasis on sexual relationships and the emphasis on sex to advance the plot. Also, another very important peculiarity of the noir narrative is that its protagonists are self-destructive individuals. Stylistically speaking, this narrative retained the direct writing style and the gritty realism of "hardboiled fiction." The term "noir" fiction may evoke a sentiment of pounding gloom and a portrayal of a fatalistic world. However, in many literary works of this style there is room for humor, a characteristic not present in the previous style. Among the most celebrated authors of the early noir narrative it is essential to mention James M. Cain, Cornell Woolrich, Dorothy B. Hughes, Jim Thompson, David Goodis, Charles Williams, and Elmore Leonard. I also find it necessary to mention that Raymond Chandler, whose literary career expanded for

\footnotetext{
${ }^{2}$ Later in this section we will discuss the origin of the term "noir" fiction by studying Patricia Hart's postulates about the term.
} 
several decades, not only was an influential figure in the evolution of the crime/detective fiction during the 1920s with the appearance of the "hardboiled" literature, but also helped shape the modern "noir" fiction.

Chandler was educated in England, but he spent a great deal of his intellectual time studying in great depth the American literature of the $19^{\text {th }}$ century and that of the early years of the $20^{\text {th }}$. To Chandler, the detective genre was a true example of good literature and he dedicated himself to the production of such good literature. According to Frank MacShane, Chandler once stated that he dedicated himself to writing true fiction by employing the structure of the detective novel (MacShane 29).

The author of The Long Goodbye (1953) —one of his most popular works—was among the first writers that revolutionized the genre in the early decades of the $20^{\text {th }}$ century. Even though he did not identified himself as a writer of the social realism trend that dominated the narrative of the time, he maintained that social realism thought gave the detective genre its transcendental feature. For Chandler, the literary detective work of Dashiell Hammett, whom he considered his greatest influence, has a well-deserved place in the contemporary literature of the United States. For him, Hammett's work was a true reflection of contemporary social circumstances in the United States during the first two decades of the $20^{\text {th }}$ century; just as the work of Ernest Hemingway, Theodore Dreiser, Ring Larner, Sherwood Anderson and even Walt Whitman reflect the American panorama of the epoch. Chandler's admiration for Hammett and his work as a writer of detective narrative is based on his recognition of Hammett's attempt to develop a crime story that was a true reflection of the real world in which it might have taken place. In his detective stories, Hammett was able recreate the reality lived in the most callous 
world in which crime was at the center stage. In such world, Hammett's characters acted and expressed themselves as the people who associated themselves with the world of the gangster. Many of these characters are very manipulative and controlling in their illicit endeavors. The narrative depicted the world of the night club owner or barman who facilitated a safe location for illegal transactions among criminal to take place; of the waitress who also had to employ herself in other forms of unlawful acts in order to make ends meet; of the police officer who must put his life on the line for the well being of his community; and of the detective who would not rest until the case he was working on was resolved and the criminal paid for his offence against society. The detective narrative of Hammett is part of the literary works that focused on depicting the sociopolitical circumstances of the first decades of the $20^{\text {th }}$ century in the United States. For Chandler, Hammett is the first writer to make use of the detective narrative to create a mimesis of the real world as other of his contemporary American writers were doing in other narrative forms.

Another important definition of the noir novel is found in an essay by Thomas Narcejac's entitled "Le roman policier," which appeared in 1958 in the third volume of the Historia de las literaturas, published by Gallimar under the direction of Raymond Queneau. For Narcejac, the origin of the noir narrative can be found in the following two essential elements: the element of creating a mystery and the element of the rational thought that would help resolve the mystery. Narcejac saw the detective narrative as a true descendant of the popular horror genre of the $19^{\text {th }}$ century; hence the noir genre is also considered as a thriller narrative because from the horror narrative it inherited the element of suspense. Narcejac also explains that the noir is closely linked to the 
positivist thought of the $19^{\text {th }}$ century and that modern necessity of explaining all aspects of reality. Under such conditions, he explains, the first detective narrative was born: "Visceral and cerebral at the same time" (Gubern 34). The noir subgenre is a narrative that would not appeal to sentimentalisms. For Narcejac, it is a type of fiction that would encompass mystery and emotions on the one hand, and rationalism on the other. According to him, Poe's close chamber mysteries are true representations of the classic detective narrative. Another interesting fact pointed out by Narcejac is the link that he observes between modern noir fiction with the realist narrative of Balzac and Dickens and the novel of the Far West of the United States. In this very important essay about the definition of the noir genre, Narcejac also makes a distinctive separation between the detective narratives produced in England and the ones produced in France. For example, he explains how in the contemporary works of the French detective tradition Georges Simenon occupies a well-regarded position because he is responsible for revolutionizing such tradition. In French letters, Simenon incorporated a psychological element for the first time to the task of going about solving the mystery as presented in noir fiction. Narcejac makes the distinction between the English and the French noir tradition from that of the American one by also alluding to the idea that the noir narrative produced in the United States makes an attempt to be a true reflection of reality and the writers of this narrative are concerned about the credibility of the situations presented in their narrative. As a result, contemporary noir narrative came to be more concerned about the reason why a crime was committed - "the why"- as opposed to the earlier preoccupation depicted in the classical tradition of the genre about the "who" committed the crime and "how" was it carried out. In said essay, Narcejac analyzes the progression of the 
detective narrative throughout the different time periods it has existed: from the period of the gothic inspired mystery novel to the classical (the rational and positivist) detective narrative that eventually transformed itself into the contemporary noir fiction.

Another interesting definition of the modern noir narrative to be considered in a discussion of this narrative is the one proposed by Patricia Hart in The Spanish Sleuth. The Detective in Spanish Fiction. In the introductory chapter of her book, Hart recounts the various terms that have been used to describe detective fiction. She first establishes that the detective novel is "a book that revolves around the investigative process of a detective" (13), and mentions that the term "roman noir" first appeared as a term used to categorize a body of literature, which main focus was the investigation of a crime, written in the United States and published by the editorial Gallimard and that appeared in black covers; hence the adjective "noir." Hart also establishes that even though the above mentioned fact about the noir narrative was responsible for its popularity during the 1930s and 1940s one can simply ignore the term "noir narrative" and refer to this narrative as "detective fiction" without any other concern. However, the author makes the suggestion that what came to be known as the noir genre in the European literary criticism circles "eventually came to mean a detective novel in which the flatfoot is a loner and often a loser, in which the underside of society is displayed on a bleak, black canvas" and that eventually the term "noir" also came to be used to refer to films with such elements (13-14).

${ }^{3}$ Hart also makes the notation that the term "roman noir" does not have a literary translation in English because if one were to speak of "The Black Novel in America' you are talking about the works of black authors, not detective fiction" (13). 
The interest of the European reader in the narrative produced by Hammett and Chandler (among other writers) was not on the murder-mystery elements of this fiction, but instead they were fascinated by the bleak social realism depicted in these novels. The European reader did not see the connection of this narrative with the detective fiction of Sir Arthur Conan Doyle, and saw it rather as a type of social protest. However, the American critics disagreed with their European counterparts and did not see the new detective narrative as true examples of social realism works. For them, this type of fiction was defined more as a group of literary works that appealed to the masses because of its entertainment and escape values. They commented on the conventions used to develop the story line and most importantly they criticized the appearance of mythical characters that became the protagonist of such stories and eventually came to be stereotypes for noir novels and films. According to Hart, "[t]he American critics perceived these books as a new and dramatic form of escape fiction, and usually commented on their style, rather than their social contents" (13).

Javier Coma — whose definition of the noir genre we have cited earlier - in $L a$ novela negra, realismo en la novela policiaca comments on the divided view between European and American critics as regards to the noir genre. He states that the reason the American noir fiction readers and critics categorized it as literature of escapism and failed to see its social realist value was because for them the detective novels of Chandler, Hammett and many others whose work were being published in magazines such as "Black Mask" never seemed truly realistic. The reason for such categorization from the Americans, according to Hart, is that when compared to other American social realist literary works produced at the same time noir narrative did not seem as accurately 
depicting the harsh American experience of the times. Also, they read the books within the context of the life they saw around them. Hart states that:

These two factors restrained them from believing as whole-heartedly as their European counterparts in the total verisimilitude achieved in these books.... It simply never occurred to the American critics to label these novels as realistic, for to them they seemed as convention-filled as those of Agatha Christie..." (14-15)

According to Coma, the European reader of the American detective novel — that read them through translation— believed that they were getting a realistic account of American urban life from these narratives. One must remember that this body of fiction was among the first to gain wide readership throughout Europe. The novels were read as true portraits of the sadistic and corrupt world of the gangster and of political machines in full operation. They saw them as true reflection of the criminals in their natural habitat speaking and acting as they truly would in their everyday reality. Such ideas had a great impact in the writers of noir fiction later produced in Spain and Latin America, for the noir fiction produced in these regions reflected a desire to portray the underside of society in a starkly realistic light. ${ }^{4}$

\footnotetext{
${ }^{4}$ Later in this chapter, I will concentrate on the discussion of the noir narrative in Latin American, but at this point it is suitable to mention that the noir narrative produced in Latin America is characterized by a conscious attempt from the novelists to incorporate a social realist element. This element is one of the most defining characteristics of the genre in Latin America, just as it is for the noir fiction of Spain as studied by Hart and Coma. In a nutshell, these novels can be defined as detective novels that make an attempt to create a critical realism.
} 


\section{3. Typifying Characteristics of the Classic Detective and the Noir Narratives}

Perhaps among the most read literatures around the world are the detective, mystery or crime literature, and its variation that eventually came to be regarded as noir fiction. We must also observe the fascination that these narratives have evoked in readers around the world since detective fiction first appeared in the 1800s. Another interesting fact about detective and noir literatures is that, in spite of their great popularity and their long tradition, they were considered as "less serious literature," by the academic world until rather recently. They were considered, for a very long time, for mass consumption with very little literary value and not deserving of critical analysis. The vast popularity of the detective and the noir novels, their industrial and mass distribution in pulp magazines, and in the movies and television contributed to devaluing their literary prestige.

Those who considered these literary productions as pulp fiction and "less serious literatures" did so by arguing that these kinds of narratives were convention-filled literature. This is a very valid argument considering that the detective and the noir narrative are characterized by a series of typifying elements. In order to successfully engage his or her reader, the writer of these kind of formulaic literatures must face the challenge of producing stories within the parameters set by the genres without losing the interest of the reader with boring repetitions, while at the same time meeting the reader's expectations. In section I. 2, I briefly mentioned a few of the characteristics of the noir narrative as explained by some experts on this narrative form. In this section, I will reevaluate some of the already mentioned characteristics of the noir narrative and add some others as I compare the typifying aspects of both classic detective fiction and noir fiction. Among the most significant characteristics of the classic detective narrative and of the 
noir narrative that I must highlight — in order to understand how different they are from each other - are their aesthetic and ethical components.

Even though in the classical detective novel, there isn't an explicit attempt from the writer to advocate for the preservation of a particular ideology, it is easy to point out an ideological referent that foreground the ethical believe that "crime never pays." The referent shows a faith in the judicial system and the aim to maintain society's status quo. This ideological referent is well explained by Jose Colmeiro when he notes that:

A pesar de que el propósito central del detective de la novela policial clásica no es defender el orden social imperante, su actuación siempre conlleva de manera indirecta una defensa implícita de la sociedad establecida, lo cual otorga a la obra un sentido moral muy distinto. Encubierta bajo la apariencia de un mero juego estético la novela policial clásica posee una fuerte carga ideológica que, escudada en las corrientes cientifistas o positivistas (la experimentación, el proceso inductiva y deductiva, la investigación), se inclina sin ningún lugar a dudas hacia el mantenimiento del Status quo social. Por su total confianza en la ley y el orden burgueses, y su defensa del bienestar de clase (puesto en peligro por el avance de las clases populares) este subgénero de la novela policial manifiesta una postura moral conservadora que protege la estructura social.

Puesto que los ataques que ésta sufre pueden ser neutralizados por ella misma utilizando medios racionales, la novela policial clásica tiene un efecto tranquilizador, a manera de antídoto que devuelve la seguridad 
individual y colectiva tras la amenaza desintegradora. Para ello y para que los móviles del crimen parezcan verosímiles, la novela policial de tipo clásico necesita la formula del "final feliz", en la que el crimen (misterio, infracción y amenaza) se resuelve perfectamente y sin ninguna ambigüedad, lo cual ofrece una visión optimista de las posibilidades de regeneración de la sociedad, así, tras las aparente inocentes formulas narrativas de la novela-enigma se transparenta toda una mitología apologética del orden establecido jurídico-burgués (61).

Even though the noir narrative is an offspring of the classical detective novel they do not share the same ethical foundation. The moral element of maintaining the established social norms perceived in the classical detective novel is not present in the noir narrative. In the noir novel, the detective or the structure of the search serves as an excuse to articulate the various moral dilemmas faced by an individual in a particular society. As per this regards, Colmeira states that:

La novela policial negra supone una inversión del orden y signo de los principios éticos y estéticos. Aquí se mantiene la temática criminal como juego estético (suspense, misterio, ingenio) pero su importancia queda ahora desplazada o reducida con respecto al componente ético, que tiende ocupar generalmente un lugar predominante. Diríamos que el problema formal del rompecabezas funciona como excusa o armazón para la articulación del problema moral de la actitud del individuo frente a la sociedad (61-62). 
Thus, the reactionary element of the noir novel against the previous form of detective fiction can be seen in the incorporation of moral and ethical elements that foreground the reaction of mankind against corruption and social injustice.

La novela policial negra parte de una desconfianza total en la sociedad y sus instituciones. La constitución de la sociedad se considera intrínsecamente injusta e inmoral, basada en el dominio del poderoso sobre el débil, del rico sobre el pobre, a través de la explotación y la violencia; la inmoralidad de esa sociedad es mas palpable todavía al ir apareada con el fenómeno de la corrupción de los políticos (que hacen y deshacen las leyes a conveniencia de los poderosos y, si es preciso, hacen pacto con los criminales) y la corrupción de la policía (que se deja comprar al mejor postor), lo cual trae consigo un debilitamiento de la confianza en la ley y la justicia. Estas formulas narrativas de la novela negra son indicativas de una nueva mitología popular cuestionadora del orden establecido (62).

The mistrust in the bureaucratic institutions, in the judicial system and in many of the core values of a particular state became important aspects of the noir literary tradition. In Latin American letters, especially in the Central American new noir narrative-as we shall explain in the following chapters-, this mistrust in government officialism has caused noir narrative writers to engaged themselves in a constant monitoring of society's obscure mechanisms that have led to social injustice, terrorism, exploitation and death and portrait them in their work. The two main categories of the detective genre, the classical and the noir, present two opposing, and apparently irreconcilable, worldviews. 
Even though, both contain the same aesthetic element of the detective search-though in different degrees and importance-, it is in their specific ethical element where their main difference and their most defining characteristic are found.

\section{3. 1. Typifying Characteristics of the Noir Narrative}

Many of the characteristics of the noir narrative described in the following paragraphs were inherited from classical detective fiction. One of the most important features of this literature that I have already discussed and that was inherited from the classic style is the presence of an unsolved puzzle that creates an atmosphere of intrigue and suspense from the very beginning. Another outstanding characteristic of the genre is the incorporation of a simple style of language. The narrative makes use of the colloquial language spoken by common people. The characters in the detective narrative express themselves in short telegraphic phrases, using idiomatic language. The novels incorporate the language of the police officers, of the gangsters, of people who inhabit the callous world that serves as the stage for the events depicted in this kind of fiction.

A third characteristic of the noir narrative is that its protagonists are not classic heroes or people of letters, in most cases. For the most part, they are individuals on the run from the law, unemployed journalists, retired army officers, alcoholic police officers and detectives who have a very grim vision of the world. Characters that recreate the world of the gangster, where the crime takes center stage, populate the detective narrative. Thus, the only fit language to recreate such environment is that of the argot, it is the manner of speaking that corresponds to the man on the street, of the policeman and

of the gangster. This simplicity of the language in the noir narrative helps to recreate the 
"super-realism" that has also characterized this kind of narrative. Thus, noir fiction is identified by the mechanism in which intrigue and suspense are created and by the incorporation of specific kinds of characters that speak the language of the streets that help recreate a kind of social-determinism.

A fourth characteristic of the noir genre is that unlike the narrator of the classical detective novel who is an omniscient narrator that knows all the details of the plot, the narrator of the noir fiction has multiple functions: he/she is a witness, a narrator and a protagonist. This character ignores the behaviour of the other characters and is completely unaware of what is going to evolve from the plot. In such circumstances, the psychology of the protagonist is revealed to the reader through a technique that is known as stream of conscience. The technique of describing the action of the story as opposed to explaining it is very defining of the noir genre produced during the years between the two World Wars. I must note that this is a feature inherited by the new modernist American literary projects of the first part of the $20^{\text {th }}$ century that revolutionized the literary world, and it is a trait that still prevails in the new forms of noir narratives being produced.

I. 3. 2. Summary of the Main Characteristics of the Classic Detective Novel and the Noir Novel

I have summarized the main similarities and difference between the two most popular styles of detective novels in the following sections. 
- Classic Detective Narrative:

a. It is firmly rooted in the ludic literary aspect of solving a puzzle presented by an enigma or a mystery.

b. The plot and the element of intrigue is based on the development and circumstances of a criminal act that goes beyond reality.

c. The structure is characterized by following the same argumentative pattern. The reader knows beforehand what will unfold through the novel. There is a criminal act - usually a murder -, a series of suspects and an investigation. The novel follows a set structure by which a mystery will be solved, justice will prevail and the wrong doers or criminals will be forced to face the law. Through the structure of this novel, it is easy to note a struggle between good and evil.

d. The theme will always be the same: a criminal act, which deploys the investigation.

e. The only character that stands out is the detective, although sometimes the victim is briefly described. Usually, the detective is a professional that runs a detective agency. In some cases the detective is an amateur who enjoys the challenge of solving an enigma.

f. The ideology, as stated before, emphasizes a defence of the established social order. It encompasses a conservative social attitude for a bourgeois inspired judicial system.

- Noir Narrative:

a. It is rooted in presenting a form of social criticism. 
b. The plot and the element of intrigue are based on the psychology of its characters or in the presentation of an inevitable situation that progresses towards violence. Most importantly, it attempts to mirror reality as much as possible.

c. The structure is rooted in some of the elements of the classic detective novel, but it breaks away by foregrounding the element of suspense in the mystery. The suspense in the novel is brought about by a detailed description of a gory environment that recreates an atmosphere of violence, terror and death.

d. The main theme will always be the investigation of a criminal act; however, there are other themes that will be deployed by the investigation. These secondary themes will present a sort of social criticism to a specific social or political system. Violence, torture and death brought about by a repressive government system are examples of these themes.

e. The main character is depicted as a man of skin and flesh as common as any other who rarely is presented as a thinking machine of exceptional brilliance. In many cases, he or she is determined to be a lonely anti-hero figure full of vices. The detective, for the most parts is not a professional detective. In many cases the main protagonist is not the main detective, but rather a person who gets involved directly or indirectly in the investigation of a crime because of certain circumstances.

f. The ideology as stated before, foregrounds a social criticism of a specific social or political system in which oppression, violence and death are everyday occurrences. 


\section{4. What Then Constitutes the Noir Narrative?}

Taking into account what has been stated about the noir genre- the influences of the gothic novel and of the adventure stories of the Far West, the rationalism inherited by the literature of the late $19^{\text {th }}$ century and the social criticism observed by critics outside the United States in the work of writers such as Hammett and Chandler-, it can be stated that there are three essential forms of the noir narrative: a) the noir narrative that is filled with action and that has a detective as its protagonist ; b) the noir narrative that is told through the point of view of the criminal; c) the noir narrative that is told through the point of view of the victim. ${ }^{5}$ These are three forms of the noir fiction that I will take into account in the analysis of the Central American noir novels that I will study in the consecutive chapters, however, it is important to mention that there are several other variations of these classifications. As mentioned before, the noir narrative is a very popular genre and the production of this type of fiction is abundant. Mempo Giardinelli in El genero negro has come up with the following taxonomy: 1) the detective novel in which the protagonist is an astute detective; 2) the novel that is told from the view point of "Justice"; 3) the psychological thriller that portraits the anguish and despair of the criminal mind; 4) the novel of espionage; 5) the novel that has at the center stage contemporary urban life and that through the incorporation of a crime develops a mechanism of intrigue and that attempts to create a social criticism of certain aspects of contemporary urban society; 6) the novel in which an innocent victim gets involved in a crime and must prove himself/herself above suspicion of such crime; 7) the novel of persecution, in which either the victim or the criminal are being sought after; 8) the

\footnotetext{
${ }^{5}$ See Mempo Giardinelli.
} 
thriller, the novel that attempts to provoke strong emotions in its reader in which the suspense lays in the expectation of something terrible to occur. From this classification, I observe how the noir narrative is open to a vast number of expressive forms in which elements of the real world are recreated in the work of art.

The contemporary noir narrative saw its birth in 1925. Frank MacShane in his already cited biographical work of Raymond Chandler alludes to the birth of the genre the precise moment when Joseph "Cap" Shaw, an aspiring writer who served as a captain in the United States Arm Forces took control of "Black Mask" magazine. Shaw knew enough about detective stories and he understood that the readers of "Black Mask" were tired of the enigmatic plots that lack real life human emotions and values. He took notice of Dashiell Hammett's work in previous editions of the magazine, corresponded with him and shared with him what he had envisioned for the magazine and its fictional content. Among other things, Shaw wanted for "Black Mask" fictional work that would involve a great deal of action, but that would also depict characters that would embody real life emotions (123). Shaw knew that the detective fiction was convention filled and along with Hammett started to visualize a detective narrative that would encompass the inherent problems of the human condition and those imposed by society in the resolution of a crime. With such a scheme, Shaw and Hammett broke away from the detective genre characterized by the enigma or mystery story that writers such as Sir Arthur Conan Doyle made famous. All this means that what truly defines the contemporary noir narrative is not the crime per se; what defines it is that the crime, in the noir narrative, is the central theme of the narrative, the starting point by which a true reflection of the real world is 
conveyed. The crime in the noir narrative is the central theme by which all the action of the novel and the human drama and conflicts are provoked.

Hammett created with his first and perhaps best novel Red Harvest (1927) a new mold for the detective fiction with this new scheme of what constituted the detective narrative. In this new literary modality, he recreates a true reflection of American society with its Christian set of values and the human nature of the individuals that make it up. Hammett's novel portrays American society of the late 1920s and 1930s with as much rigor as Cervantes portrayed the decadent Spanish society of the late 1500s. From then on, in the novels and short stories written by Raymond Chandler, James Cain, Horace McCoy, Jim Thompson, Truman Capote and Chester Hime, among many others, crime in literature is a real entity, and its multiple and potential causes cannot be determined by simply discovering the individual who commits the crime because the causes of a crime many a time are rooted in the social system in which the criminal operates. Hence, the contemporary noir narrative is an x-ray of contemporary society. The noir narrative is an excellent format by which authors and readers can make sense of and question the world in which we now live. Alfonso Reyes and Jorge Luis Borges, came to such realization and defined it as "the classic genre of our times" (Yates 11). Therefore, to call it a "less serious literature," is to ignore the fact that in the crime one can find one of the most basic explanations of human nature, as seen in works such as the ones produced by Homer, Dante, Shakespeare, Cervantes, Dostoevsky, etc.

In the English detective genre, most specifically the one popularized by Sir Arthur Conan Doyle, the social motivations of a crime are ignored. However, in the new noir tradition presented in the United States by Hammett and later produced in France, Spain 
and Latin America, motives and reasons for a criminal action are recognized as endemic problems of society. Each delinquent action is motivated by especial social circumstances that stimulate an individual to commit offending action. In the contemporary noir narrative, the resolution of a mystery crime or how it was produced does not matter. What is truly important is to recognize that a crime is committed for a real reason and that the reason is caused by human weakness such as ambition, envy, hate, fear, revenge, passion and even love, among others.

\section{5. The Noir Genre in Latin America}

In Latin America, the first manifestations of the detective narrative are attributed to Jorge Luis Borges and Adolfo Bioy Caseres who in 1940 wrote a series of stories with features of classic detective fiction. These stories were collected in Seis Problemas por don Isidro Parodi; other stories that incorporated the classic detective style written by Borges such as "La muerte y la Brújula" were published in Borge's collection of short stories Ficción. We must also mention that features of the classic detective narrative can be easily recognized in Ernesto Sabato's novel El Túnel.

The detective narrative with a poignant social criticism, what has come to be known as the noir fiction, began to appear simultaneously during the second half of the 1970s in Latin American countries such as Mexico, Argentina and Cuba. These new trend of detective novels in the Latin-American letters was inaugurated in Mexico by Paco Ignacio Taibo II, creator of the detective series in which the detective Hector Belascoaran Shayne was in charge of the investigations, and by Rafael Ramirez Heredia. As precursors of the noir detective novel in Cuba, I can mention the writers Ignacio 
Cardenas Acuña and Justo E. Vasco (who co-authored the novel Completo Camagüey y Primero Muerto with the Uruguayan Daniel Chavarria). In Argentina writers such as, Rodolfo J. Walsh and Oswaldo Soriano established the noir tradition.

The narrative produced in the United States during the first half of the $20^{\text {th }}$ century changed the course of the history of literature. There is no doubt how influential this body of literature has been for contemporary writers around the world. This revolution in literature can only be compared to that produced by Miguel de Cervantes and his creation in the 1600s of the first modern novel. The American writers of the 1920s and 1930s generated a new form of recreating reality in the work of fiction. They were able to observe and discuss everyday reality and transfer it to artwork in an innovative form. In short stories and novels, these writers recreated the most miserable aspects of human nature denounced the abuses caused by the political machinery; depicted how little an individual's life can be worth and portrayed the individualism, the racism, the violence and the hopelessness that were part of American society of the time. With these literary works, these writers came to be influential to generations of writers especially those of Latin America.

In the previous section we discussed how the origins of the detective narrative go back to the serial narrative of the second half of the $19^{\text {th }}$ century. I argued that this narrative was characterized by crime and mystery and by resolving an enigma by finding out who committed the crime without paying much attention to the credibility of the story. To put in Raymond Chandler's words "they are narrative that are too little aware of what goes on in the world" (The Simple Art of Murder 11). In the previous section I also took note of how the work of writers like Raymond Chandler, James Cain, Horace 
McCoy, Jim Thompson, Truman Capote and Chester Himes - what can also be classified as the "tough writers" of the American detective novel—, revolutionized the art of writing a murder mystery story by adding elements of the real world to this formulaic narrative. Violence, real aspects of the human psyche and of the everyday reality that surround us made these stories more credible and made crime an important aspect of the real world we live in. Before them, reality was outside the detective narrative and that is precisely what the noir narrative now incorporated to the body of literature. A character in these stories, just as any average individual, would have to face the potentiality of facing danger, the misery, the racism and the violence of individualist American society by the simple act of stepping outside his or her place of dwelling. This is the material that inspired the work of American noir writers and the work of others like William Faulkner, Erskine Caldwell, Nathanael West, Carson McCullers, James Baldwin, Ernest Hemingway, Scott Fitzgerald, John Steinbeck, Richard Wright, Truman Capote, J.D. Salinger, J.P. Donleavy, Patricia Highsmith, Raymond Carver, Eudora Welty, John Irving, Donald Barthelme, Paul Auster and many others who incorporated the reality of the American experience into their narratives.

The American noir narrative, just like the social realist genre, has been of great influence in the contemporary Latin American narrative. To this respect, Mempo Giardinelli states that:

Estamos convencidos de que la novela policial ha ejercido una extraordinaria influencia sobre la moderna narrativa latinoamericana, y esa influencia está referida, casi completamente, a la novela negra estadunidense. Esa "norteamericanidad" está en el espíritu mismo que 
recorre los textos de la mayoría de los escritores latinoamericanos de lo que se ha dado en llamar el "postboom" y no es otra cosa que el crudo realismo de la acción novelada, la rudeza y verosimilitud de los diálogos y hasta la posibilidad de representación dramática que tiene la narrativa norteamericana: es un hecho que ha sido el gran manantial proveedor de temas y tramas para la industria del cine y la televisión. Y ese carácter esencialmente estadounidense ha extendido su influencia a otras literaturas: lo han asimilado autores europeos del género (Hadley Chase, Cheeney, Giovanni, P.D. James, Vázquez Montalbán y Francis, entre otros) y obviamente también los latinoamericanos. (226)

The influence of the American narrative, not just of the noir genre, has been well recognized by many Latin American writers of the boom generation and of the generation that followed. But speaking of the "tough writers" and their influence in Latin American noir writers, it is essential to list the names of Rodolfo J. Walsh, Juan Sasturain, Carlos Martini in Argentina; Poli Délano and Ramón Díaz Eterovic in Chile; Ricardo Pérez Valero and Luis Rogelio Nogueiras in Cuba; Rafael Bernal, María Elvira Bermúdez and Paco Ignacio Taibo II, Rafael Ramírez Heredia and Eugenio Aguirre in Mexico to name a few.

One important fact to note is that even though these Latin American noir writers were greatly influence by the narrative of their American predecessors they do not fall victim to imitation. On the contrary, each and every one of them have been able to adapt the techniques, the narrative form and the way of observing and recreating the decadent society that serve as the stage for these stories, but at the same time they maintain their 
own personal style. The Latin American noir narrative incorporates the themes of racism, violence and hopelessness that also appear in the American noir genre, but in the case of the Latin American narrative these themes are adapted to its reality.

In the American noir narrative, two essential motives for a crime to take place are money and corruption. It can be said that such motivations are present in almost all the American literary production of the noir genre. The genre is defined by the presence of crime, and it is motivated by the desire to obtain easy money. However, this obsession for the easy acquisition of money cannot be observed as a determining factor for the motivation of the criminals in the Latin American noir fiction in most cases. We must take into account that the influence of the American noir narrative on the Latin American one is found in the techniques used to recreate the real world - it is in the method employed for narrating - and not for the motivations of the story. In the Latin American noir fiction, the motivation for a crime to take place in most cases is provoked by the social differences that the possession or lack of money creates. In these novels, the reader witnesses the misery and the struggle for acquiring money in order to survive or to accumulate vast quantities of money. In the Latin American noir tradition, more important than money are the effect of its unjust distribution. Therefore, this fiction makes a realistic portrayal of the economic and political crisis lived in the Latin American countries and the social marginalization and degradation of certain sectors of the population because of their limited means caused by unemployment, among many other social problems. One thing that the American and the Latin American noir fictions have in common, however, is the incorporation of corruption as one of their major themes. Police corruption, political corruption and individual moral corruption are at the 
core of the noir genre. While in the American noir tradition these forms of corruption are treated as the motivation for characters to gain access to easy money and employ themselves in illicit acts and are accepted as irreparable social evils, in the Latin American noir fiction the corruption is treated as the result of the dreadful conditions caused by unjust distribution of money. Such condition proves once more how in the Hispanic American literary world writing is not only an esthetic condition, but also an ethical one. Violence and corruption in the Latin American noir fiction are circumstantial social evils and they are never accepted as beyond repair. ${ }^{6}$

\section{6. The Birth of the Central American Noir Narrative}

The popularity of the noir narrative in Spanish speaking countries can be calculated simply by adding up the vast number of titles that have been produced in Spain and Spanish America since the early years of the $20^{\text {th }}$ century. In Central American letters, however, this genre does not seem to have a long history. This is an area of Latin America where the novel itself emerged rather late, and it seems that the production of the noir genre can only be traced back to the second half of the 1980s. Very few examples, if any at all, of such novels can be found prior to said date. ${ }^{7}$ The consequences

${ }^{6}$ For more information on the similarities and differences on the American and the Latin American noir fictions, please see Luis Rogelio Noguera (1982).

${ }^{7}$ I must note that the appearance of the noir genre in Central American fiction occurred at the same time that American and European scholars consolidated the literary production of the isthmus as an area of study. This also coincided with the attention given by the Reagan Administration in Washington to the area, attention that turned the international gaze to the isthmus. Central America came to be known as a region filled with violent guerrillas and heartbreaking civil wars. The focus of the literary criticism in the United States and in Europe of the Central American literary production of the time 
of the Nicaraguan, Salvadoran and Guatemalan civil wars of the 1970s and 1980s brought about a significant body of literary production that contextualized the political struggles of the area. They were texts considered revolutionary fiction, literature of the guerrilla, and of course of testimony. It is in this realm that a type of literature that resembles the noir genre emerged in Central American fiction. These novels do not fit neatly within the generic classification of the detective or noir narrative; however, they allude to and play with the conventions of the genre. They are all characterized by an insidious sense of violence, corruption, decay and disillusionment. Criminality and injustice are themes at the core of these novels and in most cases it is the state the ultimate source of such corruption. All of these elements are present in the five novels that will be studied in this dissertation.

The Central American noir narrative shares these characteristics with those being produced throughout Latin America; however, it also displays several distinctive features. The most distinctive feature found in the Central American noir fiction is the deep disillusionment with the outcome of the revolutionary struggles and the utopian project of the 1970s and 1980s in the region. This characteristic contrasts with the utopian projects of the revolutionary Left that can be sensed in noir fiction produced in other parts of Latin America. Another interesting way in which the Central American noir fiction distances itself from that of the rest of the continent is that in it there is a constant referentiality to the preceding literary tradition of the narrative of testimonio. They create a parody of the narrative by presenting historical events narrated by fictional characters

was on how the literature of the region became an instrument of resistance and political struggle. 
as opposes to real historical figures. The Central American noir narrative is the product of the radical socio-political changes that the region has suffered in the latter part of the twentieth century; changes that often are its main theme.

\section{7. Historical Contextualization of the Central American Noir Narrative}

The Central American noir narrative, as mentioned above, is a product of the radical historical changes that the region saw during the political struggles of the last decades of the $20^{\text {th }}$ century. Violence, extreme poverty, social inequality and the use of repressive force to quiet down peaceful demands for social change by the dictatorial governments that controlled the power in many cases for more than thirty years - as it was the case in Nicaragua - led to the organization of radical social movements. Eventually, those conditions led to the outbreak of the armed struggle that the isthmus experienced through the 1960s, 1970s and 1980s, most specifically in Guatemala, Nicaragua and El Salvador. These revolutionary movements sought not only the overthrow of the corrupt and oppressive regimes and the reinstatement of democracy, they also sought to establish a form of socialist government that would guarantee the economical stability of all the members of society, goal only achieved on July 19, 1979 in Nicaragua with the overthrow of the Somoza dictatorship by the Frente Sandinista de Liberación Nacional (FSLN). However, the Sandinistas would only govern the Central American country by a decade. During this period of time, the revolution and its initial accomplishments were broken down by an unjust hostility from the Reagan Administration of the United States, most specifically with the organization and financing of the counterrevolutionary bands (los contras) that extended the cost in both human life 
and damage to the Nicaraguan economy. Eventually, the Sandinista lost control of the government of Nicaragua in the elections of 1990 and in the wake of such defeat by democratic means the Salvadoran and Guatemalan guerrillas signed peace accords that put an end to the arm struggles that still prevailed in said countries in 1992 and 1996 respectively.

The end of armed struggles brought about some form of relief to these wardestroyed countries. However, it soon produced deep disillusionment in the population as it became clear how little was achieved by long years of war and the death of tens of thousands. Eventually, the revolutionary movements won inclusion in the political process and transformed themselves into political parties. However, their participation in electoral democratic processes up to now has made little progress to improve the social conditions that gave rise to the arm struggle in the first place. These new political parties have failed to create the social reforms and to slow down the implementation by Central American government of the free market economic and social policies, which in turn have exacerbated the region's longstanding poverty and inequality.

Furthermore, the end of the arm struggle in the area did not bring an end to violence, which metamorphosed itself into new criminal forms. The violent street crime caused by the lack of resources and unemployment, the illegal drug trade and the corruption of the new governing elite clashed with the utopian visions that inspired the revolutionary movements of the previous decades. These social conditions have cause a prevalent distrust for political parties and figures that represent them, and for the governmental institutions that are suppose to serve the needs of the population. Many see them as entities of corruption. 
These radical changes in the socio-historical context in Central America have also signaled a shift in the literary production of the region. The noir narrative, which is the subject of my study, is only one example of the new body of literature being produced in the isthmus. I must clarify that during the period leading to the armed struggle and the period that immediately followed much of the literary production was that of a politically committed literature. Writers such as Ernesto Cardenal, Gioconda Belli in Nicaragua, Roque Dalton in El Salvador and Otto René Castillo in Guatemala committed themselves to denounce the social injustice that prevailed in their native land. Another interesting fact about the literary production of this period of political upheaval in the Central American region is that the nonfiction genre that prevailed was that of the testimonio a genre made famous by Rigobeta Menchú's work. This type of narrative was very influential and a new form of fictional narrative developed from it, that of the novela de testimonio, best exemplified by Manlion Argueta's Un día en la vida (1980) and Cuscatlán, donde bate la mar del sur (1986). Both works chronicled the rise of the armed struggle in El Salvador. These literary productions are linked by common motives, that of the open criticism of the ultra-conservative, authoritarian and oppressive ruling class; and the hope to promote social changes through the solidarity and the collective action of the poor through use of armed conflict. One more fact to be considered is that the setting for this literary work was, for the most part, the countryside which was seen as the symbol for national identity and also because much of the war was fought in such setting.

During the postwar period, the literary production in Central America is characterized by a return to the narrative fiction. The productions of poetry and of the 
testimonial narrative have given way to the fictional narrative that encompass the noir sensibility and that occupies this study. Beatriz Cortez has defined this narrative modality as "aesthetic of cynicism [that is] marked by a loss of faith in utopian moral values and social projects" (6). Contrasting with the previous body of literature, this new Central American narrative form does not call for the heroic collective actions that would bring about social changes. Instead, these postwar works concentrate on depicting the individual desires, passions, and struggles for survival in these war devastated societies. Paraphrasing Horacio Castellon Moya thoughts in the matter in Recuentos de incertidumbres, we most agree with the Salvadoran writer/critic in that these narrative productions reflect the culture of survival, of the immediate present, of an uncertain and improbable tomorrow (45). This postwar fiction, unlike its predecessor, takes as its stage urban space. The main focus of this body of literature is on the effects caused by the political upheavals and arm struggle. However, one thing that it has in common with its predecessor, as Beatriz Cortez points out, is that this new form of literature lacks the idealism of wartime literature, but it shares with it the critical project of denouncing "the inaccuracy of official versions of Central American identity" (1). These postwar literary narratives express a sense of disillusionment with the socialist utopia of the earlier decades as expressed by many of their protagonists.

\section{8. Central American Noir Narrative, An Expression of Postmodernity}

With the radical political changes, the end of the arm struggle and the process of peace, the postwar Central American narrative have experimented, according to the German critic Werner Mackenbach, a change of paradigm from that of a politically 
committed literature that denounced the social injustice that prevailed in the region to a more esthetic narrative, from the narrative of testimonio to fiction narrative. The new literary trend exhibits a fragmented and more experimental narrative in which the historical past is incorporated (2008 68). Therefore, in the five Central American noir novels to be analyzed in this study (Sergio Ramirez's El cielo llora por mí, Dante Liano's El hombre de Montserrat, Horacio Castellanos Moya's La diabla en el espejo and El arma en el hombre, and Ramón Fonseca Mora's El desenterrador) I will attempt to examine how the authors of these novels are able to implement the elements of postmodern fiction writing in the fictionalization of the reality that inspired such work. For this purpose, in the following chapters, I will pay particular attention to the postulates proposed by several postmodernist critics about what constitutes a postmodern narrative. In my reading of the five novels that occupy this analyzes, I have observed that in the reconstruction of the historical past elements of the postmodern sensibility are present. Among them, I can cite: a) a parody of the discourse of the testimonial made evident in the narrative through the way in which key characters expressed themselves throughout the novels; b) the self-referentiality present in the novels by the narrations of certain historical events in which key characters took part; c) the observation of how the narrative is presented in a fragmented manner; $d$ ) the incorporation of multiple narrative voices and view points; e) by the skepticism toward history as told by the official records. Many of the characters in the novels analyzed in this study are modeled and inspired after men and women who at one point were involved in the political and revolutionary upheavals of the 1960s, 1970s and 1980s in Central America. Throughout the novels, they make multiple references to anecdotes that transfer the reader to that period of time. 
These characters make such reference to the past in many instances in humorous fashion and with an ironic tone, key characteristics of postmodern literature. All of these qualities make evident the postmodern sensibility in this new form of noir literary expression in Central America.

\section{9. An Overview of Postmodernism}

Before I begin my analysis of the five Central American novels that occupies my study and to conclude this chapter, it is essential that I present an overview of the appearance of the postmodernist cultural expression in contemporary society and outline the key features of what constitutes postmodernity. The term postmodernism gained vast popularity as a critical and theoretical concept during the 1960s. Since then, a great number of recognized intellectuals, philosophers and theorists, have formulated their postulates as to what constitutes the defining characteristics of postmodernism. Many of these theories are in stark contrast to each other; however, the majority of critics agree that postmodernism is synonymous with a form of radical skepticism and is a reaction against "fundamentionalism." With regards to what is a valid representation of postmodernist literature, many critics are in accordance that it is an offshoot of postmodernism in general, and has resulted in as much diversity. However, when it comes to determine what is a defining canon of the body of literature that best exemplify postmodern literature and deciding those authors whose writing should be included within this literary corpus, critics have engaged in a long lasting dispute. Andreas Huyssen asserts that the subject has become: “. . . one of the most contested terrains in the intellectual life of Western societies" (184). 
Historian Arnold Toynbee first coined the term "postmodern" in the 1950s. In volume VIII of his Study of History, Toynbee explains that postmodernism originated in the late nineteenth-century. For the British historian, this period in history is " . . marked by the rise of an industrial working class," a phenomenon which Toynbee equates with the advent of "mass society. . . mass education. . . mass culture" (338). For him, postmodernism is synonymous with advances in technology, and symbolizes the end of the "Modern Age" of Western society. Toynbee suggests that the bourgeoisie and previous modes of existence have been surpassed by the "postmodern" age, with established protocols abandoned in favor of social unrest, anarchy and revolution.

Romanian literary critic Matei Calinescu, In Five faces of Modernity, defines Toynbee's conception of postmodernism by stating that:

As it stands, "post-Modern" is a hazy, quasi-apocalyptic notion referring to obscure demonic forces, which, if completely unleashed, could overthrow the very structures of Modern Western civilization. "Post-Modern" in Toynbee's prophetic language suggests irrationality, anarchy, and threatening indeterminacy, and from the various contexts in which the term is used, one thing becomes clear beyond doubt, namely, that "post-Modern" has overwhelmingly negative - though not necessarily derogatory—connotations (135-36).

In Postmodernism, Modernity, and the Tradition of Dissent, Lloyd Spencer stresses the negative attributes associated with postmodernism. Spencer believes is: “... an extension of the critical, skeptical, dissenting — even nihilistic - impulse of modernity. .. Under the 'postmodern condition' dissent becomes generalized: it can seem to involve 
"dissent in principle" or even "dissent from everything possible" (161-62). Thus, it can be inferred that the diversity and ambiguity presupposed by postmodern philosophy creates a sense of uncertainty in regards to the validity of the foundations of discourse. Stuart Sim in Postmodernism and Philosophy states that the postmodernist antifoundationalists quality allows the dispute of the validity of the foundations of discourse by asking questions such as, 'What guarantees the truth of your foundation (that is, starting point) in its turn"' (3). Thus, postmodern philosophers encourage diversity and ambiguity as they question their own seeming omnipotence. According to Sim, their doctrine focuses upon:

... a rejection of the idea that there are foundations to ours system of thought or belief, that lie beyond question, and that are necessary to the business of making value judgments. Postmodernist philosophy has proved to be resolutely antifoundational in outlook, and unwilling to accept that this renders it dysfunctional in any way as philosophy (9-10).

In The Postmodern Condition: A Report on Knowledge, Jean-Francois Lyotard, asserts that postmodernism symbolizes a challenge to the authority of the established "grand narrative." As knowledge remains a privilege of a unified hierarchy, Lyotard criticizes classical knowledge systems and stresses that postmodern knowledge is based upon skepticism. He insists in that "[p]ostmodern knowledge is not simply a tool of the authorities; it refines our sensitivity to differences and reinforces our ability to tolerate the incommensurable. Its principle is not the expert's homology, but the inventor's paralogy" (xxv). 
On the other hand, Fredric Jameson, in Postmodernism and the Consumer Society, argues that postmodernism is a result of the particular cultural and socio-economic period. Jameson states that postmodernism is a diluted version of modernism. He identifies the postmodern with the advent of the age of television, and corresponding growth of the media. Jameson suggests that postmodernism is:

... a periodizing concept whose function is to correlate the emergence of new formal features in culture with the emergence of a new type of social life and a new economic order - what is often euphemistically called modernization, postindustrial or consumer society, the society of the media or the spectacle, or multinational capitalism (113).

As per the creative perspective, Jameson distinguishes two main characteristics in the postmodern cultural expression. The first one refers to the "reaction against the established forms of high modernism, and [the second] to the rise of an aesthetic populism sympathetic with mass culture and kitsch" (Juan-Navarro: 18). The postmodern artist tends to express himself/herself by crossing the boundaries between disciplines and movements and also, by using traditional marginalized artistic forms such as the kitsch, TV, films, and literary subgenres like romance, detective/mystery, science fiction, comics, and fantasy.

In summary, taking into account the above mentioned interpretations of postmodernism, I can argue that postmodernism stands as an extreme version of skepticism, a continuation of the modernist tradition, or, a concept pertinent to the ethos of contemporary society. The ambiguity and inclusive nature of the concept constitutes the stark contrasting opinions and contentions regarding its defining qualities. 
In The Postmodern Turn, Ihab Hassan details the ambiguous nature of the concept. Hassan highlights the problems encountered by those who have attempted to define postmodernity. He states that:

[t]he word postmodernism sounds not only awkward, uncouth; it evokes what it wishes to surpass or suppress, modernism itself. The term thus contains its enemy within. . . Moreover, it denotes temporal linearity and connotes belatedness, even decadence, to which no postmodernist would admit. But what better name have we to give to this curious age. . . shall we call it the Age of Indetermanence (indeterminancy + inmmanence). . . Or better still, shall we simply live and let others live to call us what thy ma? (87).

Hassan was among the first critics to constructs a concept of American literary postmodernism, and explores the various techniques employed within post-war fiction. The prevailing features that Hassan observes as representation of the postmodern is the exacerbation of a tendency already existing in modernism and the avant-garde: "the way to unmake," that is a tendency for deconstruction and the recuperation of popular culture. In Hassan's opinion, American postmodernism symbolizes a radical alternative to that which had existed previously. As all universal certainties of the modernist model are replaced by perpetual doubt and anxiety, these reflect the collective mindset. Hassan states that postmodernism represents a rupture from the modernist project, and lists a series of thirty-three schematic differences that separates postmodernism from modernism (267-268). Hassan investigates the way in which the modernist established cornerstones have been reinterpreted by postmodernism. He argues that, while Modernism “. . . created its own forms of artistic Authority precisely because the center 
no longer held, Postmodernism has tended toward artistic Anarchy in deeper complicity with things falling apart”(44-45). As such, postmodernism opts for chaos and a sense of dislocation, authority is rejected in favor of the intrusion of the unpredictable: antielitism, antiauthoritarianism. "Diffusion of the ego. ... Irony becomes radical, self-consuming play, entropy (disorder) of meaning" (41). Postmodernism paves the way for the inclusion of discerning and multiple voices, and is opposed to the structures imposed by the controlling elite. Thus, the established conservative ethos is rejected in favor of diversity and radicalism: "The Counter Cultures, political and otherwise. . . Rebellion and Reactions!" (43). Similarly, the modernist metropolis has been distorted into an impersonal, post-apocalyptic environment, which is exemplified by lack of connection, brutal violence and collective annihilation. Irrationalism is employed as a means of communal expression and suppression: "Meanwhile, Dionysys has entered the City: prison riots, urban crime, pornography, etc. Worse, the City as holocaust or death camp: Hiroshima, Dresden, Auschwitz" (40).

Matei Calinescu, whose work I cited at the beginning of this section, asserts that postmodernism represents a continuation of the established modernist ethos, and is merely one face of a "larger modernity." In Five Faces of Modernity, he explores the ways in which postmodernism is influenced and determined by the remit of the modernist tradition, and is a successor to other artistic movements that have gone before, namely kitsch and the avant-garde. In his conclusion to Five Faces of Modernity, Calinescu states:

We perceive these varied faces as related because of their common association with a larger modernity and with its spirit. Where it not for this 
larger modernity, the partial similarities and the expressive differences among these faces would melt away and become meaningless. We would no longer be attracted to compare and contrast them. We may then assume that as long as we compare and contrast them, modernity survives, at least as the name of a cultural family resemblance in which, for better or for worse, we continue to recognize ourselves (180).

The ideas of Matei Calinescu in regards to the "postmodern "age of modern society can be viewed as a continuation of modernity, as a symptomatic of the crisis of belief that occurred in the wake of the repercussions of the Second World War and can be compared to Jameson's assertion that postmodernism is related to global capitalism, and is a reflection of the ethos of contemporary society and its interdependent relationship with mass media. With regards to literature, Calinescu acknowledges that the concept of postmodern literature is defined by an overwhelming sense of diversity:

Over the years a corpus of postmodern writing (or, more accurately, writing that is often referred to as postmodern) has thus emerged. I should add, however, that there is nothing rigid or fixed about this corpus, and that in fact it is wide open to revisions, exclusions, inclusions, and even fundamental challenges. . . I see it simply as the product of a historical hypothetical perspective from which certain questions about the nature of contemporary writing can be asked (296-97).

Among the characteristics that Calinescu considered to be defining of postmodernist literature, he highlights: 
The proliferation of images and actions directly or indirectly linked to the idea of representation: mirrors and copies, reflections and duplications, the unexpected and intricate paradoxes of resemblance, pretending, acting, impersonating, or mimicking, and the various mental predicaments they bring about, in the shape of vicious circles, begging of the question, and infinite regresses (300).

Calinescu asserts that defining traits associated with literary postmodernism include: “... references to epistemological problems and concepts, such as the crisis of determinism, the place of chance and disorder in natural processes" (269). Calinescu believes that prose works, which distort the notion of conventional truth, adhere to the tenets of literary postmodernism. As such, these novels address the recurring postmodern question:

Can literature be other than self-referential, given the present-day radical epistemological doubt and the way in which this doubt affects the status of representation? Can literature be said to be a "representation of reality" when reality itself turns out to be shot with fiction through and through? In what sense does the construction of reality differ from the construction of mere possibility? (299).

Calinescu suggests that literary postmodernism is primarily associated with epistemological problems and concepts. He provides several examples of these concerns, which include, “. . . the question of time and particularly irreversible time (whose recognition has displaced the powerful classical clockwork model of the universe)" (269). 
Thus, I can infer that the concept of literary postmodernism have provoked numerous debates with the purpose of reaching its defining tenets. There is, however, a general consensus of opinion with regard to its broadest and most evident defining characteristics. Postmodern literary devices include ontological skepticism, foundational indeterminacy, and overwhelming lack of cognitive certainty. In the subsequent chapters, I will argue that these postmodern literary devices are evident in the five Central American novels studied in this thesis and that their authors have been able to implement the elements of postmodern fiction writing in the fictionalization of the reality that inspired such work. El cielo llora por mí, by Nicaraguan writer Sergio Ramirez; El hombre de Montserrat ${ }_{2}$ by Guatemalan writer Dante Liano; La diabla en el espejo and El arma en el hombre, by Salvadorian writer Horacio Castellanos Moya; and $E l$ desenterrador, by Panamanian writer Ramón Fonseca Mora exemplify the unique characteristics of what can be classified as postmodern and revolutionary Central American noir narrative. 


\section{CHAPTER II}

\section{SERGIO RAMIREZ'S EL CIELO LLORA POR MÍ: (RE)INVENTING FACTS- CONSTRUCTING “HISTORIOGRAPHICAL” NOIR FICTION}

\section{1. History in Sergio Ramirez's Literary Project}

Sergio Ramirez is part of the generation of Latin American writers who began his literary career after the so-called "Boom" period in the Hispanic letters. Ramirez published his first narrative works in the1960s and since then, his work has been of great significance not only in the Nicaraguan literary realm, but also in the Central American and Latin American literary circle. From the publication of his first collection of short stories in 1963 to his most recent novel La fugitiva (2011), Sergio Ramirez' literary production is characterized by the representation of paralinguistic signs of the sociopolitical situation in Central America's recent history—more specifically Nicaragua's recent history. Ramirez's literary production emphasizes the different tendencies in the political, historical and esthetic discourses during the multiple periods of social change that the Central American region has experienced since the early years of the $20^{\text {th }}$ century. Furthermore, Ramirez' creative work stresses the complex relationship between the extra-literary reality and the fictional representation of reality. In his narrative, there seems to be an almost obsessive concern for (re)writing history. One of the ways the Nicaraguan writer accomplishes this fusion of fiction and reality is by the (re)construction of legends and myths of certain historical figures like Ruben Dario, the Somoza clan, Augusto C. Sandino and of revolutionary figures who play important roles in the social changes brought about by the Revolution of 1979 in Nicaragua. In novels 
like Castigo Divino (1988), Margarita está linda la mar (1998, Premio Alfaguarra de Novela) and El cielo llora por mí (2008) - just to mention three titles of a long list of fiction and non-fictional works-Ramirez makes use of experimental narrative techniques such as dialogic, carnivalist and parodic elements, multiperspectivism, intertextuality, metatextuality and metafiction to refer to obscure areas of the historical past and thereby creates a concrete representation of Nicaragua's past and present-day reality.

Castigo Divino-Ramirez's third novel—can be categorized as what critics have called "The New Latin American Historical Novel." In this novel, Ramirez recreates the events that took place during the investigation of a questionable criminal case in Leon, Nicaragua, during the 1930s, and by doing so recreates an entire epoch. The beginning of an authentic judicial process through which the authorities attempt to find answers to the mysterious and sudden death of one of Leon's wealthiest merchants, Don Carmen Contrera, establishes the plot of the novel. Oliverio Castañeda, a lawyer and ex-diplomat from Guatemala who running away from political persecution came to live in Leon, is accused of multiple murders. In perhaps the most high profile court case that the city of Leon has ever had, Castañeda is suspected of having poisoned his wife, Marta; the oldest daughter of the Contrera family, also named Marta; and the patriarch of the Contreras, Carmen Contrera. The authorities and everyone else believed that Castañeda committed all these murders in order to seduce the youngest daughter of the Contreras, Maria del Pilar. His motive is thought to have been to marry Maria del Pilar and by doing so appropriate the family business and wealth. Contrera is also suspected of having committed other homicides in Guatemala and Costa Rica. Castigo Divino has been also 
categorized as the inaugural literary work of the new noir narrative modality in Central American letters because of the elements of the police investigation and of the mystery behind the murders. ${ }^{8}$

The novel consists of over four hundred and fifty pages and is dived into fortyeight chapters, grouped together into four parts plus an epilogue. The narrative work is a colossal fictional text written, figuratively speaking, on top of the various judiciary documents referred to by the narrator as a:

... voluminoso expediente levantado día tras días a partir del 9 de octubre de 1933, fecha del fallecimiento de Don Carmen Contreras; allí se acumulan incontables declaraciones de testigos, exámenes forenses, actas de exhumación, resultados de pruebas de laboratorio, dictámenes periciales, recortes de periódicos, cartas y muchas otras piezas probatorias y documentos que el Juez consideró de mérito agregar. El 24 de diciembre de 1933, cuando fue suspendido abruptamente el proceso, el expediente constaba ya de mil ochocientos noventa y dos folios útiles (92).

Ramirez's text is a fictional account of the real events that occurred in Leon Nicaragua in 1933. His narrative, however, is in a manner of speaking written on the evidential texts of the court case against Contrera. The events that inspired the novel and the themes presented by the author, present the socio-political situation of Leon in the 1930s and evidence Ramirez's concern for the history of Nicaragua.

\footnotetext{
${ }^{8}$ See Misha Kokotovic (2006).
} 
In Margarita está linda la mar, published in 1998 - ten years after Castigo

Divino - Ramirez again finds his inspiration in two historical periods in Nicaragua's

resent history: Ruben Dario's 1907 triumphal return to Nicaragua after being away for a

long stay in Europe and the events prior to his death in 1916; and the historical visit of

Anastasio Somoza Garcia ${ }^{9}$ to the city of Leon, Nicaragua on September $21^{\text {st }}, 1956$ where

${ }^{9}$ Anastasio ("Tacho") Somoza García (1 February 1896-29 September 1956) is the founder of the Somoza dictatorship in Nicaragua. He was officially the President of Nicaragua from January 1,1937 to May 1, 1947 and from May 21, 1950 to September 29, 1956. He ruled effectively as a dictator from 1936 until his assassination in 1956.

Somoza was born into a wealthy coffee planter family and received his career training as a business administrator at the Pierce School of Business Administration (now Peirce College) in Philadelphia, USA. After returning to Nicaragua, he was unsuccessful as a businessman, but because of his impeccable unaccented English, he was able to embark in a very successful political career.

Somoza joined the Liberal rebellion in support of the presidential claims of Juan Bautista Sacasa, his wife's uncle. Although Somoza failed to distinguish himself in battle, his English language skills allowed him to act as an interpreter during the U.S. intervention during the period of negotiations between the warring parties. In the government of President Jose Maria Moncada, to whom he was distantly related, he served as governor of Leon, as Nicaraguan Consul to Costa Rica and as Foreign Minister. Despite his limited military experience, Somoza was able to rise through the ranks of the Nicaraguan National Military forces.

After waging a bitter, six-year struggle with the forces of General Augusto C. Sandino in January 1933, the Marines evacuated the country, following the election of Juan Bautista Sacasa as President. At the urging of the U.S. Ambassador Matthew E. Hanna, Somoza García was appointed as director of the National Guard.

During peace talks, Somoza ordered the assassination of General Sandino on February 21, 1934 in violation of a safe-conduct agreement. Sandino's assassination was followed by the murder of former Sandino supporters by the National Guard. In June 1936, Somoza forced Sacasa to resign.

A series of puppets ruled for the remainder of the year, and in December Somoza was elected president by a margin of 107,201 votes to 100 - an implausibly high margin that could have only been obtained through massive fraud. He took office on New Year's Day 1937. Somoza, popularly known as "Tacho," amended the Constitution to centralize all power in his hands. Family members and key supporters monopolized key positions in the government and military.

While opposition parties continued to exist on paper, in practice the system was heavily rigged in favor of Somoza's Partido Liberal Nacional. Throughout the 1930s and 1940s, he acquired immense personal wealth, primarily through investments in 
shortly after being nominated by his party to run once again for the Presidency of Nicaragua, received a fatal shot by a young political activist. Many historians have considered this date as the beginning of Nicaragua's Revolution, for it was on this day when Rigoberto Lopez Perez, a young poet and social activist, fatally shot the Nicaraguan President who died several days later. ${ }^{10}$

Just as in Castigo Divino, Ramirez in Margarita está linda la mar reconstructs, not one but two historical epochs which correspond to the two axes of the novel: Dario's returning to Nicaragua and his death in the first decades of the $20^{\text {th }}$ century and the events preceding the assassination of Somoza in 1956. In addition, in the latter novel as he had done in the previous one, Ramirez blurs the boundaries between reality and fiction by mixing real historical events and figures with fictional accounts and characters and creates a palimpsest, typical of the historical novel genre. The writing techniques that Ramirez employs in this novel evidence that particular element of la nueva novela histórica. Once more, we can note Ramirez's obsession for (re)constructing history, as he also does twenty years later after the publication of Castigo Divino and ten years after Margarita está linda la mar in El cielo llora por mí. In the following sections of this chapter, I will consider elements of Sergio Ramirez's El cielo llora por mi that help identify it as belonging to the new literary modality of noir fiction in Central America, a modality that exhibits many characteristics of postmodern fiction writing.

agricultural exports, particularly coffee, cotton and cattle. See Jose Dolores Gamez (1993)

${ }^{10}$ Ibid 


\section{II.2. Sergio Ramirez's Literary Postmodernity}

To talk about postmodernist Central American literature may appear to be an odd proposition, especially because of the controversy that the use of the term has caused in studies of Hispanic American postmodernity. Many literary critics of the SpanishAmerican letters have been hesitant to deal with the topic of postmodernism. Some of them link the term with the "modernista" movement of the late $19^{\text {th }}$ century, while others are quick to point out the anachronism of using the term to discuss cultural expressions produced by societies that, in some cases, have not even reached modernity. The term postmodernism, used here to refer to the socio-historical reality and artistic production of Spanish-American countries, is an alien concept for many. ${ }^{11}$ This dissertation, which focuses on noir fiction written in Central America during the 1980s and 1990s attempts to demonstrate that this sort of contemporary fiction produced in the isthmus reflects many of the typifying characteristics of postmodern literary works, for they are characterized by many of the main components of postmodernist literature produced elsewhere. For example, one of the postmodern characteristics identified in this analysis is the use of a metafictional structure in a paradoxical combination of historical facts and fiction. Through a textual analysis of these contemporary novels, we will attempt to establish some of the distinctive features of what might constitute the new Central American postmodern noir fiction.

${ }^{11}$ For a more detailed analysis of the discussion on the postmodernist debate in Latin American, see Jean Franco (1989), George Yúdice (1992), Colás (1993) and JuanNavarro (1995). 
The contemporary Central American narrative is an amalgam of styles and discourses. The present-day literary production in the isthmus is still linked to the testimonial account, to the historical, the political, the mystery and the thriller literature. This creative production is an attempt to recreate the chaotic contemporary times, and at the same time, it is an artistic product that depicts the persistent war against social injustice. The body of literature being produced by present day Central American writers exhibits the multiple characteristics of the postmodern cultural expression. Werner Mackenbach defines Central American literature as "historias de amor en tiempos de guerra, pero entendiendo ahora como guerra no únicamente las confrontaciones militares sino también el ámbito de la posguerra: la violencia urbana, la lucha entre géneros y los conflictos internos de los individuos." The current Central American narrative is a fiction in which violence - marked by the unjust distribution of power in the neo-liberal capitalist economy—take center stage.

I investigate the specific conditions of the production of Sergio Ramirez's literary postmodernity as presented in his novel El cielo llora por mí in this part of my dissertation. I intent to demonstrate in this chapter how in this new literary paradigm Ramirez invariably blurs elements of fact and fiction within his narrative to create a contrast between the previous Central American literary productions, characterized by the hope to promote social change through the solidarity and collective action of the poor through the taking of arms, and the new narrative form which foregrounds the individual desires, passions and struggle for survival in the new neo-capitalist economic system. I suggest that this blurring of fact and fiction creates a thoroughgoing skepticism that lacks any definitive sense of coherent certainty, all markers of postmodernity. I shall focus my 
discussion on some of the formal techniques and properties of Ramirez's novel and analyze how they parallel the techniques of postmodernist formal literature as presented by three of the major postmodernist theorists: Ihab Hassan, Brian MacHale and Linda Hutcheon. However, before analyzing Ramirez's work, a brief summary of the novel is required.

\section{II.3. El cielo llora por mí: An Introduction}

El cielo llora por mi (2008) is the second to the last novel published by Ramirez. The novelist in this work of fiction makes use once again of experimental narrative techniques such as dialogic, carnivalesque and parodic elements, multiperspectivism, intertextuality, metatextuality and metafiction to create a concrete representation of present- day Nicaragua. These fiction-writing techniques signal the entrance of postmodernist fiction in Central American letters. In his novel, Ramirez reviews and questions the revolutionary past of Central American recent history. He gives voice to historical figures, such as the revolutionary militants, who once were heroes, but now because of political corruption brought about, among other things, by drug-related crimes, have become marginalized citizens. The novel narrates the story of Inspectors Dolores Morales and Bert "Lord" Dixon. Both are former Sandinista guerrilla leaders who, once the revolutionary period came to an end and with no other social destiny, became inspectors in the anti-narcotic division of the Nicaraguan National Police. Morales and Dixon as members of the police force continue the fight against social injustice and remain loyal to their revolutionary ethics. Morales and Dixon represent those individuals who are still faithful to the revolutionary values and have not been 
bribed by the greed of easy money and power. Thus, Ramirez in the novel reveals the poor living conditions of those Nicaraguans heroes who made life-altering sacrifices for the Revolution, and for a governing system that ultimately failed them because of its many corrupt leaders.

Ramirez wrote his novel using the suspense of the noir genre style and keeps the reader wondering who killed Sheila Marenco, victim and accomplice of drug trafficking, and who orchestrated the clandestine meeting of two major drug kingpins in Nicaragua. He also builds suspense by introducing an abandoned luxury yacht in the Caribbean coast of Nicaragua. The social landscape of contemporary Nicaragua looms behind the underworld crime of the casinos, corrupt politicians and money laundering.

The biggest surprise behind the mystery in Ramirez's novel is the incorporation of a female character, doña Sofia Smith. She is a friend and neighbor of Inspector Morales, she works as a janitor in the Nicaraguan National Police Headquarters, and she is an avid reader of detective novels. Doña Sofia's great intuition helps Inspectors Morales and Dixon solve the puzzle and close the investigation. Doña Sofia's courage and her belief that criminals should be punished place her in very dangerous situations, particularly when she volunteers to go as an undercover agent and enter the den of crime.

Doña Sofia plays an important role in the novel. The police would have not been able to dismantle the illegal operations of a gang of drug smugglers in Nicaragua without her help. To think of doña Sofia as a detective, is perhaps a far-fetched idea. The reader is lead to wonder how a woman in her 60s appoints herself as an anti-narcotic detective and basically solves the crime. Doña Sofia's character seems to be contrary to the realistic tone of the novel; however, this fictional character may have been inspired by classic 
characters of the detective genre such as Arthur Conan Doyle's Sherlock Holmes, or Hercules Poirot or Miss Marple of Agatha Christie's novel — the latter one is a closer match to Ramirez's amateur detective- - Miss Marple, like doña Sofia, is an elderly woman who acts as a clever detective in twelve of Christie's novels and twenty short stories. Like these classic detectives, doña Sofia makes use of the inductive method of investigation and at the end of the novel her skills help put the criminals in jail. Doña Sofia's talent for creating clever hypotheses that help solve the mysteries- the finding of an abandoned luxury yacht in Pearl Lagoon — is the result of working for many years as a janitor in the National Police Headquarters, where she astutely observes and absorbs how police business is conducted. We must also add that this sort of "informal training" is complemented by doña Sofia's shrewd intelligence, her fascination for detective literature and most importantly her conviction to fight injustice and criminality. These two aspects of her moral character are the result of her Christian and Revolutionary ethics. Thus, through the use of analogies and rationalism doña Sofia is able to weave together the pieces of information acquired little by little in the course of the investigation carried out by Dixon and Morales. We must also mention that in the novel, the sociocultural changes that occurred before, during and after the Nicaraguan Revolution facilitated the changes in social expectations related to the roles traditionally assigned to women. Many Nicaraguan women played an active role before, during and after the overthrow of the Somoza dictatorship. In the novel, doña Sofia represents and celebrates the sacrifices and activism of Nicaraguan women during this historical period. The elements of doña Sofia's character mentioned above help the reader come to an 
understanding of how an elderly woman takes an active role in the fight against the social evils that effect Nicaraguan society of the present day.

\section{II.4. The (Re)construction of the Narrative Space in Ramirez's Novel}

As stated before, Sergio Ramirez invariably blurs elements of fact and fiction within his narrative and by doing so creates a sense of skepticism as to the certainty of reality. The violent street crime caused by the lack of resources and unemployment in the new economic system, the illegal drug trade that is on the rise and the corruption of the new governing elite serve as evidence in the novel of people's distrust of the official political discourse of Nicaragua characterized by social and economic progress. My discussion of Ramirez's novel will focus in this section on how some of the formal techniques and strategies that Ramirez utilized in El cielo llora por mi parallel the techniques of postmodernist formal literature as presented by three of the major postmodernist theorists, Ihab Hassan and Brian MacHale, and Linda Hutcheon. According to Ihab Hassan, postmodernism consists of two impulses: 1) the will to (self)dissolution, and 2) the challenge of institutionalized high art. He defines postmodernism by what he calls "indeterminance." Hassan uses this term to highlight the postmodernist artists' will to unmake. The drive to deconstruct is characterized by artists' use of ambiguity, discontinuity, heterodoxy, pluralism, randomness, revolt, perversion and deformation in their artistic productions. The second element in Hassan's conceptualization of "indeterminance" is immanence, the capacity of the mind to diffuse and disseminate itself. According to Hassan, languages "reconstitute the universe. . . into 
signs of their own making, turning nature into culture and culture into an imminent semiotic system" (1987 172).

For Brian MacHale, postmodernism represents a discursive construction that in fiction signals a shift in the "dominant." According to Yury Tynyjanov and Roman Jakobson, the dominant is the central component of a work that governs, determines, and transforms all the other elements in the work. McHale takes from these theorists the concept of the dominant, but unlike them he conceives multiple dominants in a work of fiction. McHale states that while the dominant of modernism is epistemological, the origin of postmodernism is ontological.

The epistemological concern in literature attempts to understand the problems of knowledge and the interpretation of being. The ontological concern in literature attempts to reflect upon the nature of literature and its problematic relation to the outside world. In Postmodernist Fiction (1987), McHale describes the strategies that postmodern fiction uses to foreground the ontology of the text and of the world. According to the American theorist, one of the ways in which postmodern fiction highlights this ontological concern is by the analysis of fictional space. Whereas modernist texts are organized around a fixed perspective, either of a character or of a detached narrator, the "heterotopic" space of postmodernism can be simultaneously constructed and deconstructed by multiple devices that he calls "juxtaposition, interpolation, superimposition, and misattribution" (1987 45). Through the use of these strategies postmodernist writers can set the ontological limitations of fictional worlds-limitations that can easily be simultaneously constructed and deconstructed, established and transgressed. 
McHale, in his analysis, also focus his attention in the metafictional aspect of literary postmodernism. McHale argues that postmodernist fiction is concerned with the order of things and therefore a postmodern work of fiction is in itself a discourse that reflects upon discursive worlds (1987 164). For example, this heteroglossia or plurality of discourses manifested by the juxtaposition of languages, styles, and diverse registers in postmodern fiction can be achieved by discursive polyphony through the use of dialogical confrontation between the anti-language of the subculture and the official language of a particular society. Thus, it can be noted that McHale adopts from Mikhail Bakhtin the concepts of "polyphony" and "carnivalization" in his discussion of the self-conscious character of postmodernism. In his theorization of postmodernity, like Hassan, McHale recuperates all of the popular artistic forms that challenge the institutionalized high arts. In McHale's paradigm, particular attention is given to the popular genres associated with the tradition of carnival.

Another aspect taken into account by McHale in his theorization of the postmodern work of fiction is what he categorized as "construction" and discusses the indeterminacy that is characteristic of the level of "represented objects" which as opposed to real objects, are universal and unequivocally determined, "represented objects"according to the American theorists — show a space of indeterminacy that tends to be filled in provisionally through the act of reading. Mechanisms such as the Chinese box structure, Mise en abyme, trompe-l'oeil effects or infinite regress typically used in postmodern work of fiction highlight the subversion of the structural frame of the fictional work. 
One final comment made by McHale in his definition of a postmodern work of fiction deals with the actual form of the book. He analyses the way in which postmodernist texts use, for their own benefit, its own ontological substances. He comments how the structure of the literary work rests on the physical book and its typography. The use of titles, headings, concrete prose, photographs, illustrations, texts in multiple columns, and the non-chronological enumerations of chapters conform what MacHale calls the "schizoid text" in which visual and verbal discourses cross each other in polyphonic attitudes.

For Linda Hutcheon, postmodernism is characterized by a tendency toward metafictional narrative (Narcissistic Narrative, 1980). The focus of her study is centered in the architectonic forms and she sees in architecture a "double code" that she equates to that of postmodern fiction. For her, both artistic expressions respond to modern codes as well as to those of popular and local character. Hutcheon sees in the contemporary architectural form a combination of historical memory, the urban context and the participation of the public realm; thus, making it pluralistic and eclectic. Likewise, she argues, postmodernist fiction seeks to create a democratic space in which the reader, the writer and the critic are capable of taking part in the literary process or recreating reality. We must not forget that postmodern literature is characterized by experimental forms, hence its interest in playing with multiple possibilities of meaning and forms. The techniques of self-reflexive narrators and of defamiliarization also help conceive this kind of literary artifice in contemporary literature.

In A poetics of Postmodernism (1988), Hutcheon focuses her discussion of postmodernism in the increasing emphasis of historicization reflected in the postmodern 
discourse. The Canadian critic highlights aspects of theory and practice that point toward the creation of a concept of postmodernism that can incorporate both postmodern culture and the discourse of it. The objective of this poetics is to justify the paradoxes that result from the confrontation of the self-reflexive forms of modernism and the new interest for the historical, the social and the political elements that characterize postmodernist artistic productions.

Hutcheon's version of postmodernism is often juxtaposed with that of Fredric Jameson who laments the lack of critical capacities to which postmodern subjects have access, and analyses present capitalist cultural production in terms of a dehistoricized spatial pastiche. On the contrary, Hutcheon highlights the ways in which postmodern modalities actually assist in the process of critique. Hutcheon suggests that postmodernist works through parody "both legitimize and subvert that which it parodies" (Politics of Postmodernism, 1989 101). "Through a double process of installing and ironizing, parody signals how present representations come from past ones and what ideological consequences derive from both continuity and difference" (1989 93).

Therefor, far from dehistoricizing the present or organizing history into an incoherent and detached pastiche, postmodernism aids the artist to rethink history and shed light on new critical capacities.

Hutcheon coined the term "historiographic metafiction" to describe those literary texts that emphasize an interpretation of the past but are also deeply self-reflexive-i.e., critical of their own version of the truth as being partial, biased, incomplete, etc. $-(1988$ 122-123). According to the critic, this is the most representative element of postmodernism. The postmodern literary work bear the false impression that they enjoy 
fictional and linguistic autonomy in reflecting upon themselves and upon their own course of creation and reception, an illusion that the text itself finally dismisses. In addition, the inclusion of historical characters and situations in the fictional setting points toward the weakening of the pretenses of objectivity and empiricism of historiography as claimed by most traditional views of history writing. New concepts of history such as the ones postulated by Hayden White, Lionel Grossman, Louis Mink and Dominick LaCapra conceive history as unable to escape from the limitations of all cultural constructions in the exploration and expansion of the nature and limits of theoretically informed historical understanding. Thus, "historiographic metafiction", allows individual to engage in the practically discussion about the past in a way that acknowledges the inaccuracy and violence of the historical "objective" of the past without leaving the individual in a totally puzzled and isolated present as Jameson suggests it. ${ }^{12}$

\section{II.4.1. Fact and Fiction in El cielo llora por mi}

One way by which Central American authors, like Sergio Ramirez, accomplish the mixture of fact and fiction in their narrative works is by incorporating in their novels historical/factual events and characters whose biographical backgrounds depict the reality lived in war-affected countries like Nicaragua. The majority of their fictional protagonists appear to be versions of individuals who were involved, some way or another, in the political armed struggles lived in the isthmus in the latter decades of the $20^{\text {th }}$ century and whose experiences serve these authors as vehicles to construct new

\footnotetext{
${ }^{12}$ For a more structured summary of Hassan's, McHale's and Hutcheon's commentaries on postmodernism, see Juan-Navarro (1995 8-16).
} 
perspectives of historical accounts and question the official discourse of the present day governments. Following Linda Hutcheon's concept of "historiographic metafiction" and Ihab Hassan's postulates of "self-dissolution" or "immanence" - the capacity of the mind to diffuse and disseminate itself - and the will of the artist to unmake, we can argue that Sergio Ramirez resorts to the [re]invention of historical facts and characters in the course of his fictional narrative and composes "historiographical" fiction based upon the experiences of ex-revolutionary figures like him. By doing this sort of reinvention of history, Ramirez in his novel presents the typifying characteristics of postmodernist fiction of historical skepticism and the lack of any definitive sense of coherent certainty of reality. The novelist also makes a social criticism of the current state of affairs in the Central American nation. In Ramirez's novel, these elements are evident by the reconstruction of the memory of the experienced lived by individuals like him who played a major role before, during and after the revolution. However, even though Ramirez was a key figure of the revolution, in his novel he is careful not to compose an "autobiographical" fiction. The predominance of narrative perspectives evident within the novel, ensure that he distances himself from authenticity and accountability in the plot of El cielo llora por mí. Ramirez creates "historiographic metafiction" through the process of diffusion and dissemination of the collective experience of revolutionary figures like himself in the construction of the biographical past of his characters in his novel. By doing so, the novelist recreates the feeling of skepticism and lack of coherence of postmodernity. He accomplishes this by presenting a new perspective in which historical facts and fiction are blurred in this new form of literary form, which we can denote as the new noir narrative in Central America. 
The main characters of El cielo llora por mi are: Inspector Dolores Morales, Inspector Bert "Lord" Dixon and doña Sofía Smith. If we take into account what Hassan determines as "self-dissolution" - that capacity of the mind to diffuse and disseminate itself-, we may note that these three characters show multiple aspects of individuals who were involved in the revolutionary acts that brought about the social changes in Nicaragua during the ninety seventies and eighties. They appear to be different versions of the revolutionary heroes who still remain faithful to the revolutionary values and have not been bribed by the greed of easy money and power. The life accounts of these three characters are very closely linked to the actual events that took place before, during and after the Nicaraguan Revolution. ${ }^{13}$ In the novel, their biographical background show what we argue is Ramirez's obsessive concern for the rewriting of history. For Ramirez's fictional project, the imaginative space serves as the space to (re)invent, to

${ }^{13}$ The Nicaraguan Revolution (Revolución Popular Sandinista, also RPS) encompassed the rising opposition to the Somoza dictatorship in the 1960s and 1970s. The Revolution was led by the Frente Sandinista de Liberación Nacional (FSLN); it culminated with the insurrection that ousted the dictatorship on July 1979, and by the efforts of the FSLN — which governed from 1979 until 1990 - to reform the society and economy of Nicaragua along socialist lines. The Revolution played a significant role in foreign policy not only for Nicaragua, but also for the entire region. The concurrent civil war, waged between the FSLN and the Contras, was one of the proxy wars in the Cold War.

The Revolution was influenced by three major historical events: 1) The Nicaraguan guerrilla warfare led by Augusto César Sandino who stood with only 29 men, against the U.S. intervention in 1926. He developed an armed rebellion to fight the U.S. In 1934, Sandino was betrayed and assassinated by Anastasio Somoza García. Sandino became an icon of the roots and birth of the Nicaraguan Revolution. 2) The Cuban Revolution that sparked widespread Left wing revolutionary movements across Latin America. 3) The fall of the Berlin Wall in 1989, event that weakened the Soviet Union and ended the Cold War. This event preceded the end of the Nicaraguan Revolution as marked by the electoral defeat of the FSLN in 1990. The liberal governments that followed changed much of the Revolution's legacy. The FSLN, evolved into a leftist party that won the Nicaraguan elections in 2006. 
reinterpret the past, and to show its conflicting relationship with Nicaragua's present day reality. Inspector Morale's, Dixon's and doña Sofia's personal histories serve as the most appropriate imaginative space by which Ramirez diffuses and disseminate the collective experience of many of Nicaragua's revolutionary heroes and everyday common people who support it. In creating the biographies of these characters, the novelist blurs fact and fiction in an attempt to revise the past and denounce the abuses caused by the political machinery and the poor living conditions in which ex-heroes of the Revolution and many Nicaraguans live in the new neo-liberal society.

Inspector Morales' life account in the novel serves as the main axel by which a mural of Nicaragua's revolutionary past and its conflict with today's reality is constructed by Ramirez. Inspector Dolores Morales is a true parody of the hardboiled detective whose job as an inspector in the anti-drug unit and his self-destructive vices helps him overcome the emptiness associated with his present day existence as an ex-military without any glory. ${ }^{14}$ His name is ironic, for his personality is totally the opposite of what it stands for "Moral Sorrows." According to Lord Dixon, he should have been called "Placeres Físicos"-_Physical Pleasures"- because his most visible vice is that of being a womanizer. Morales would seek the company of prostitutes until a whore who could not have been more that 17 years old infected him with a sexual transmitted disease. Since then, he would frequent low class neighborhood bars on his way to his house and would stay drinking beer until very late at night, avoiding the temptation of falling victim

\footnotetext{
${ }^{14}$ I will discuss more in depth the role of Morales as a detective in the noir tradition in a later portion of this chapter.
} 
to these sort of women and avoiding going to an empty house. Now, he would have causal sexual encounters with Fanny, a sexual partner whom he sees sparingly. Morales would try to seduce any woman that he would find attractive. He was married once, to a Panamanian who took part in the Nicaraguan armed struggle. Although they were not legally married, for they were married under the creed of the militia and by none other than Father Gaspar Garcia Laviana, a Spaniard missionary from Asturias who worked closely with the Nicaraguan peasants and was intimately aware of the many hardships they faced. ${ }^{15}$ After the revolution, Morales and Eterna Viciosa formed a home in Managua. Tired of Morales vice for women and his drinking habits his wife, Eterna Viciosa (which literary translation of the name would be Eternally Vicious Woman), left him one day. Furthermore, Morale's fictional accounts of his participation in the armed struggle are very closely linked with García Laviana's actual participation in the revolutionary guerrilla as is noted in the following quote from the novel:

Peleando en el Frente Sur en noviembre de 1978, en uno de los combates para apoderarse de la colina 33, el mismo donde cayó el cura asturiano

${ }^{15}$ Garcia Laviana is a historical figure of Nicaragua's Revolution. He joined the progressive Christians in concientización (or awareness raising) in poor rural communities around the country. He agreed with member of the Sandinista Front that the overthrow of Somoza was a moral necessity. After agonizing soul-searching, and deep reading in church doctrine, he decided that taking up arms to fight evil did not violate his Christian principles. His decision was broadcast in two secretly distributed public letters that made clear that, with a heavy heart, he felt armed struggle was his Christian duty as a priest in solidarity with the oppressed. He was trained in explosives in Cuba, and returned to Central America and joined the "'Benjamin Zeledon' Southern Front" in the Sandinista guerrilla war against Somoza. His unit was betrayed by a traitor and was ambushed on a farm along the Costa Rican border called "El Infierno." He never lived to see the triumph of the triumph of the Revolution on July 19, 1979. 
Gaspar García Laviana, un balazo de Galil le había deshecho los huesos de la rodilla. . (14).

These facets of Morales' life—-besides showing the personal aspects of this fictional character by parodying the figure of the lonely detective of the noir genre and reflecting the solitude of the postmodern individual whose emptiness force him/her to live in a self-enforce exile from the rest of the world — give an insight into Nicaragua's past. This mixture of fact and fiction - the narration of the sexual habits of the fictional character and his participation in war combat with the allusion to the participation of one of the most revered figures of the Revolution, which symbolizes the international support that the country received during the fight against the Somoza regime- exemplifies the revision of the past that characterizes Ramirez's historiographical reflections on Nicaragua's history and his skill as a writer who is very much in tuned with postmodernist fiction writing when he resorts to both literary fabulation and historiography to portray this character.

Moreover, the fictional aspects of Bert "Lord" Dixon's biographical background are also intertwined with Nicaragua's historical events and exemplify Ramirez's way of reconstructing the past. Inspector Morales calls him "Lord Dixon" because of his impeccable good manners. He was the son of a Moravian preacher who conceived him at the age of 70. Morales used to mock him by telling him that: "Hijo de viejito sale calmado desde niño" (16). While in medical school, Dixon used to play baseball—the country's official sport and one of the people's passion —in one of the Nicaraguan's most promising baseball team "El Leon." One day, a scout of the Saint Luis Cardinals saw him playing and offered him a trial contract to play in the minor leagues in Palm Beach, 
but he dropped out of medical school and left behind the dreams of becoming a major league player to incorporate himself in the guerrilla movement at the same time when Morales also renounced his professional goals in order to join the revolutionary movement. Both characters in the novel were trained in guerrilla intelligence and fought side by side with revolutionary heroes like García Laviana — whom I have noted was a real historical figure—and by "El Apóstol” or "El Profeta”—whom, as I shall discuss later, is a fictional tacit character inspired by a real historical figured of the Revolution like many others in the novel.

One more example of how Ramirez's blurs facts and mix them with fiction in the construction of Nicaragua's past and portrayed in the novel by the personal history of his characters can be seen in doña Sophia's biographical account. Doña Sofia Smith was the illegitimate daughter of a U.S. Marine who, during the Nicaraguan intervention that ended in the1930s and can be noted as the starting point of Nicaragua's Revolution, impregnated a humble seamstress of the slums of Managua. Doña Sofia was also the mother of a young revolutionary who died in one of the battles against the Somoza regime that took place in the neighborhoods of Managua during the insurrection of 1979. During the period of Nicaragua's social reconstruction, doña Sofia was trained as a civil activist and remained active in the revolutionary movement. In the contemporary times of the novel, she works as a janitor in the Nicaraguan National Police Headquarters, in Managua. She still believes that the sacrifices made during the years of arm struggle will bring a better future for the Central American nation. Doña Sofia's life is governed by two codes of ethics: the Christian and the revolutionary. Her personal history as can be seen is closely connected to Nicaragua's past. 
Other characters of El cielo llora por mi that are inspired by historical characters and are easy recognized are "El Apóstol" or "El Profeta" and Commissioner Violeta María Barquero "La Monja," to mention only two. In the novel, the reader becomes acquainted with "El Apóstol" through the accounts that Morales and Dixon have of their paramilitary training in the clandestine operation bases in León and Zinica, Nicaragua. "El Apóstol" in the novel is described as:

... de barbita rala de chivo a lo Ho Chi Minh y lentes de grueso marco color violeta, asegurados por detrás con una banda elástica porque le resbalaban por la nariz afilada, siempre sudorosa. No entendía de bromas de doble sentido ni de historias de putas y adulterios, un monje ateo de ojos encandilados, sin sentido alguno del humor, que profesaba la castidad carnal e ideológica, e igual que los predicadores evangélicos obstinados en entrometer en cualquier conversación los textos de la Biblia, él lo hacía con los textos de Lenin que estudiaba con gozo desaforado en el encierro clandestino, cerrando de un golpe a cada trecho de la lectura el tomo de turno de la editorial Progreso empastado en tela, el dedo en medio, para quedarse reflexionando con sonrisa beatífica (37-38).

The descriptions of the personality and of the physical traits of this character are a close match to those of Carlos Fonseca Amador. Fonseca Amador was the revolutionary leader who founded the "Frente Sandinista de Liberación Nacional." He was very active in the ethic formation of the revolutionaries during the period of clandestine operations to overthrow the Somoza regime, like "El Apóstol" is said to have been in the novel. Like the historical character that inspired him, the fictional character of "El Apóstol" was a 
teacher and had a pedagogical vocation. However, unlike Fonseca Amador, who was killed in Zinica by the Somoza army in 1976 (three years before the Revolution), "El Apóstol" in the novel is said to have died drowned on his way to take charge of his appointed position as a Director of the agrarian reform projects in San Carlos, Nicaragua, a few weeks after the triumph of the Revolution.

"La Monja" is another fictional character in the novel that was inspired by a wellknown and respected revolutionary hero. I can make the argument in this analysis that Ramirez constructed the character of Commissioner Violeta María Barquero "La Monja" base on the life accounts of Commissioner Aminta Granera Sacasa, named the Chief of Nicaragua's National Police in 2006 by former president Enrique Bolaño. Like Granera, "La Monja" is also the Chief of the Police force and was in her youth a Catholic novitiate who left the convent to become a revolutionary fighter. At a very young age, both characters, the historical and the fictional, engaged themselves in the fight against social injustice. Granera, in her role as Chief of the National Police, has fought institutional corruption and has become a strong opponent to the international drug cartels who have tried to install operation bases in Nicaraguan soil. Just like "La Monja" in the novel, Granera in the political arena represents honesty and good government in a very corrupt administration.

All of these characters are a compilation of imaginary and factual elements. Their lives experiences not only help recreate Nicaragua's past and contemporary reality in the novel, but also portrait many of the Nicaragua's popular cultural aspects. As stated before, in constructing these biographical accounts, Ramirez resorts to both historiographic collage and literary fabulation. Furthermore, as can be noted by these 
biographical examples, Ramirez's historiographical view is not used in his fictional work as a mere background for a narrative plot. Instead, I can argue that Ramirez's concern for Nicaragua's history and his historiography in his artistic project attempts to engage the reader into a revision of what is considered the official historical accounts in order to shed new light into events of the past to find answers that would explain Nicaragua's present day reality. The historiographic element evident in Ramirez's novel echoes Hutcheon's concept of "historiographic metafiction."

The physical space that Ramirez characters inhibit in the novel is a world in which factual and fictional universes are mixed in the narrative space. One particular factual account that Ramirez incorporates into the novel and combines it with the fictional world of the plot is the incident of the landing of unknown airplane that is assumed to be affiliated to the international drug trade in an old inter-city Nicaraguan road. On May $20^{\text {th }}, 2006$ La Prensa one of Nicaragua's leading newspapers reported the landing of a small aircraft on the "Carretera Vieja a Leon" (Leon's Old Access Road). This aircraft was the second one discovered in the zone. In the previous month of November, the Nicaraguan National police had found in the same area another abandoned airplane with the body of two men who had been assassinated. The illegal landings of these sorts of aircrafts in Nicaraguan soil are connected to the international drug trade and as stated in the following quote, from one of La Prensa's news articles, they appear to have become frequent events in the area:

La zona donde aterrizó una avioneta misteriosa, Cessna 206, la madrugada del sábado, es parte de una nueva ruta de narcotraficantes y contrabandistas, por su cercanía con el mar, en el departamento de León. 
La Avioneta, en que la Policía encontró rastros de cocaína, quedó dañada junto a la Carretera Vieja a León.... Fuentes de la Policía Nacional dijeron que se ha vuelto frecuente el aterrizaje de avionetas de narcotraficantes, en esa zona, que luego colocan la "mercancía" en camionetas de doble tracción y la llevan a la costa del Pacífico para embarcarla (May 22, 2006).

The illegal entries of drug traffickers into Nicaraguan soil in Ramirez's novel are alluded by the mysterious finding of the abandoned yacht that deploys the investigation in the novel and by the actual textual reference of one of these airplane landings in the narration. Half way into the novel Inspector Morales, Commissioner Umanzor Selva (Morales' superior) and the US DEA (Drug Enforcement Agency) Special Agent Matt Revilla ("Chuck Norris") gather one Sunday morning to discuss the investigation of the found abandon yacht and the following dialogue held by the three characters evidence the presence of the factual world in the fictional space of the novel:

-La DEA piensa que usan también la vía aérea para traer visitantes-dijo el comisionado Selva—. Por ejemplo, el aterrizaje nocturno de la avioneta en plena carretera vieja a León, entre Izapa y Puerto Sandino, hace tres meses. La carretera está deshecha, pero en una sola noche repararon con maquinaria pesada el trecho que necesitaban.

-La avioneta se accidentó, pero ni rastro de los ocupantes—asintió Chuck Norris.

-Eso suena más bien a trasiego-dijo el inspector Morales.

-No se halló rastro de droga en la avioneta — dijo el comisionado Selva. 
-El Ioscan dio positivo-dijo el inspector Morales.

-Bueno, igual que dio en el Regina Maris [the yacht], que ya sabemos que no traía carga — dijo el comisionado Selva, con muestras de impaciencia (152).

The incorporation of the factual world into the novel is even more evident in what follows in the conversation held by the above-mentioned characters as they discuss the clandestine and illegal transit of drugs and the visits of drug kingpins to Nicaragua:

-Recuerda el avión de La Costeña—le dijo Chuck Norris. . .

-Nada tiene que ver-dijo el inspector Morales—. Esa vez fue un secuestro debido a una emergencia para sacar a Pinocho [one of Colombia's major drug traffic leaders], que había entrado por yate según piensa el mismo comisionado Selva aquí presente.

-Es lo mismo, sólo que con variantes-dijo Chuck Norris-. Nosotros cargábamos hace tiempo con esa incógnita, movimientos de medios de transportes desde Colombia, sin carga. Ahora todo calza.

-Medios acuáticos y aéreos—recalcó el comisionado Selva, mirando con reproche al inspector Morales.

-La agencia de viajes tiene un programa ambicioso, y cuida a su clientela—dijo Chuck Norris—. Tomando en cuenta los varios puntos y medios de transporte, y las frecuencias, estamos hablando de unos veinte visitantes por año.

-Distintos visitantes, o a veces los mismos - dijo el comisionado Selva-; algunos tendrán varios descansos por año porque necesitan enfriarse más. 
-Divisas frescas para Nicaragua el narcoturismo - dijo Chuck Norris, y

volvió a enseñar los dientes manchados de nicotina (153).

The preceding dialogue plays a significant role in our discussion of how Ramirez mixes the concrete world with the fictional fabulation in his novel. Ramirez is referencing how Nicaragua has become a hot spot for international drug leaders to use the Central American country as a resting place or as a hide-away destination where criminals can conduct their illicit business practices. Furthermore, what is most notably in this dialogue is the reference to the kidnapping of the Costeña aircraft. In reality, this event actually happened on July $30^{\text {th }}$, 1995 , when a Grand Caravan aircraft belonging to Nicaragua's national airline La Costeña was kidnapped by drug traffickers to smuggle back into Colombian territory one of Cali Cartel's main leader, Miguel Rodríguez Orelueja, who had entered Nicaragua illegally. ${ }^{16}$ In El cielo llora por mí, the character who chartered the airplane that eventually got kidnapped was an ex-revolutionary comrade of Inspector Morales and Dixon, Engels Paladino ("Caupolican"). After the

${ }^{16}$ Two newspaper articles evidence Ramirez's use of factual events to address the use of Nicaragua's territory as a sanctuary for major drug dealers. The first of these articles appeared in the August $6^{\text {th }}, 2001$ edition of the Nicaraguan news paper $L a$ Prensa. The Article is entitled "Secuestro de la aeronave envuelto en nube de temores y misterios." This article, which is a special report by journalist Eduardo Marenco deals with the kidnapping of a Nicaraguan aircraft to smuggle back into Colombian territory Cali Cartel leader Miguel Rodríguez Orelueja. The second article written by Vladimir Lopez, appeared in the May 30, 2011 edition of Nicaragua's newspaper El Nuevo Diario. The article is entitled "Nicaragua y el Istmo, paraíso de mafiosos." This piece chronicles the use of the Central American region, most specifically Nicaragua, as a paradisiac region where major terrorists, criminals and dirty Latin American politicians who are well known for their human rights violations and have very close ties with the international drug traffic are in frequent contact with Central American nations as they operate their elicit business practices. 
Revolution, Caupolican worked as the Chief of the Intelligence Unit of the National Security Agency, but in the contemporary time of the novel he works for the organized drug crime in charge of overseen the illegal entrance and operations of major drug kingpins and who because of his close connections with important figures in both sides of justice enjoys a much better standard of living than his two ex-military comrade. Caupolican, in the novel, represents the opposite side of Morales and Dixon. He is the figure of the ex-revolutionary who betrayed the Revolution and engages his talent and skills in the tactics of warfare gained during the years of revolutionary training because of personal profit and economic advance. Just like Morales', Dixon's, Doña Sofia’s, “El Apóstol's" and "La Monja's" "Caupolican's" life accounts serve to evidence the mixture of fact and fiction that Ramirez utilized in his novel in order to present to the reader a reconstruction of Nicaragua's recent history and one of its most current social problems the war against illegal drugs.

Ramirez's novel presents what Hassan labeled as "indeterminance" and what Hutcheon determines as "historiographic metafiction" in their postulation of postmodernism. Ramirez clearly deconstructs factual events of Nicaragua's recent past by presenting fragments of the country's history as recalled by his fictional characters as noted in the above-mentioned examples. He recreates the events of Nicaragua's revolutionary period through a pluralist tendency that incorporates the collective memory of many revolutionaries like him and opposes linearity and monologism when reading the official historical accounts of the Revolution. Ramirez is capable of creating historical skepticism that leads to the lack of a definitive sense of coherent certainty of reality in 
combining fact and fiction. These elements in Ramirez's fiction writing evidence a tendency toward a postmodernist affinity.

\section{II.4.2. Heteroglossia in El cielo llora por mí}

Another way by which El cielo llora por mí displays aspects of postmodern fiction is by the presence of a plurality of discourses within the novel. The concept of "discourse" is often misused to refer to the text; however, "discourse" refers rather to the social process in which to insert language production, while the notion of text refers to the actual object and material produced by discourses (Hodge \& Kress 6). The concept of "discourse" in this analysis is used to describe the existence and connection of various "registers of language" (microtext) simple or complex, made literally in the novel (macrotext). Thus, creating new relationships of meaning (intratextual and extratextual).

Among the multiple traits of postmodernism that Brian McHale lists in his conceptualization of this artistic mode, one of the most highlighted in Ramirez's novel is the presence of a discursive polyphony that makes evident the juxtaposition of different languages, styles and diverse registers. To this regard, Werner Mackenbach has stated that:

Desde la publicación de su primera novela en 1970, la obra novelística de Sergio Ramírez ha jugado un papel destacado no solamente en la literatura nicaragüense, sino también en la narrativa centro e hispanoamericana contemporáneas. En particular esta obra se ha caracterizado por relaciones altamente complejas entre realidade(s) extraliterarias(s) y respresentación(es) narrativa(s), así como entre historia 
y ficción y su reflexión metaficcional y autorreferencial. Al mismo tiempo es significativamente representativa de las tendencias cambiantes en los discursos político-histórico-estéticos en el contexto de los múltiples procesos de cambio social que el istmo centroamericano ha vivido a partir de los años sesenta, y las influencias recíprocas entre estos cambios discursivos y las representaciones narrativas, así como las tendencias más recientes en la historiografía y su reflexión crítica (2002 1).

I observe that the three most prevailing discourses foregrounded in Ramirez's novel are: 1) the contemporary and prevailing literary discourse in Spanish-American letters, particular the one established after the so called Nueva Novela Hispanoamericana; ${ }^{17}$ 2) the historiographic discourse; and 3) the socio-cultural discourse.

\section{4.2.1. The Contemporary and Prevailing Literary Discourse}

I discussed in section II. 4.1 how Ramirez is capable of blurring events of the past and combine them with fictional accounts in his novel through the use of "metafictional historiography." To accomplish this task, Ramirez resources to the use of a series of literary technics such as parody, multiple prespectivisms, metatextuality and metaficitional writing in order to establish a reflection on the relationship between history and fiction. This aspect of Ramirez's fiction writing demonstrates the shift in the literary

${ }^{17}$ Critics have referred to this new body of literature by many terms. Among them, we can list the following: "Novela Postmacondiana" (Valencia Solanilla 1986), "The New Latin-American Novel" (Swanson 1990; Sklodowska 1991), "Novela Postpatriarchal" (Giraldo B. 1994), "Novela del Postboom" (Shaw 1988, Lindstrom 1994) and even "Postmodern Novel" (Volek 1994, RL Williams 1995). 
discourses in Latin America that occurred in the mid-1970s when the Latin American novel suffered significant formal, verbal, thematic and discursive changes. These changes replaced the established literary canon of the prestigious literary fiction of the "Boom" of the 60's. In fact, the Latin American narrative of the turn of the $21^{\text {st }}$ century, went from the great epic and transcendental tale featured during the "Boom" to a narrative in which apparent insignificant and inconsequential events take center stage. However, the most distinguishing feature of this narrative is that of the parody, which in the case of the novel that occupies my analysis is made evident in Ramirez parody of the detective genre and of the testimonial narrative.

In the literary discourse that Ramirez utilizes in El cielo llora por mí, there is a series of elements that help him create a parody of Nicaraguan contemporary society. Among them, I observe the literary discourse presented by the noir novel. ${ }^{18}$ Ramirez adapts the structure of this genre in order to recreate the environment in which crime and corruption are at the center stage and by doing so, the novelist denounces the political corruption, the present day war against drug related crimes, and the limited resources that a country like Nicaragua have to fight these social evils.

The discourse of those individuals who represent the marginal aspects of society is another type of literary discourse present in Ramirez novel. The main protagonists of Ramirez's novel are "anti-heroic" figures whose lives are marked emotionally and physically—in the case of Morales, he lost his leg during the armed struggle — by the memories and traumas of the revolutionary project. Ramirez draws attention to multiple

${ }^{18}$ I will discuss more in depth how El cielo llora por mí, exhibits characteristics of the noir narrative in a later portion of this chapter. 
signs of social change in the last three decades of the $20^{\text {th }}$ century in Nicaragua through the use of the figure of the ex-military as a marginal character in his novel. Besides demonstrating the shift in the literary discourses in Latin America letters, these aspects of Ramirez's novel also highlight the new tendencies in historiography. The obsession for historiography is the second discursive category I detect in the novel.

\section{4.2.2. The Historiographic Discourse in El cielo llora por mí}

I must analyze the role of the Nicaraguan novelist as a historian in order to understand better the socio-cultural changes in Ramirez' literary production. Werner Mackenbach states that "existe una estrecha relación entre la Historia y la necesidad de contrala y el novelista, especialmente en Nicaragua y Centroamérica, se confrontan inevitablemente con la tarea de contar esa historia de nuevo o por primera vez" (6 2008). As noted, Ramirez's work is characterized by the accentuation of the complex relationship between the extra-literary reality and the narrative representation of it through metafictional reflection. Thus, it can be said that Ramirez's work reflects the recent trends in historiography and critical reflection, as I have suggested in earlier pages of my analysis. ${ }^{19}$

Mackenbach also points that Ramirez's fiction has gone from "una literatura comprometida con la historia y la política a la historia como pre-texto de una literatura que no ha renunciado a su afán de "contar lo no contado"” (6 2008). In addition, Fernando Ainsa states that:

${ }^{19}$ See section II.4.2 
... escritores como Ramírez se dan a la tarea de contar o recontar la Historia no contada con el propósito de presentar una relectura desmitificadora del pasado a través de su reescritura y de buscar entre las ruinas de una historia desmantelada por la retórica y la mentira al individuo autentico perdido detrás de los acontecimientos, descubrir y ensalzar al ser humano en su dimensión más autentica, aunque parezca inventado, aunque en definitiva lo sea" (31). Thus, it is through the act of writing and/or re-writing historical events that novelists such as Ramirez are able to fusion together the extra-literarily reality and the fictional representation in their literary work.

The historiographic discourse in Ramirez's novel is displayed by many of the traits already mentioned in the previous pages. As I discussed earlier, Ramirez clearly reviews factual events of Nicaragua's recent history by presenting fragments of the nation's historical accounts as recalled by his fictional characters. In this sense, the novelist recreates the events of Nicaragua's revolutionary period through a pluralist tendency that incorporates the collective memory of many revolutionaries. The historical discourse as presented through the anecdotes recalled by the characters of the novel is very closely linked to the testimonial discourse which enjoyed a privileged place in Central American literature of the ninety sixties, seventies and eighties. ${ }^{20}$

${ }^{20}$ I shall discuss the Testimonial Discourse as presented in El cielo llora por mí in section II.4.2.4 


\section{II.4.2.3. The Socio-Cultural Discourse in El cielo llora por mi}

A third discourse present in El cielo llora por mí is that of the socio-political discourse that emerged during the postwar period. The socio-cultural discourse reflects the social changes that occurred once the revolutionary projects came to an end and that the changes in the global arena. The discourse is made evident by the incorporation within the novel of themes that show the rise of urban popular culture, the emergence of consumer society, and the influence of mass media and the advent of the new era of cyber space. Ramirez's novel projects the socio-cultural discourse by foregrounding sires of sub-categories of discourses such as: the testimonial, the religious and the political. The discursive elements in many cases are marked by the commentaries made by the characters of the novel and also by those made by the omnipresent narrator. The observations made by the multiple narrative voices in the novel direct the ideology of the novel. They comment on the mistakes made by many of the leaders of the Sandinista Revolutionary Movement and the arrival of the neo-capitalist economic system and its negative consequences in the Central American nation. The novel shows the shocking economic contras between the oligarchic ruling classes whose increasing wealth seems to always be on the rise and the poor living conditions of the working classes. The novel highlights how many members of the elite are corrupt individuals who maintain close connections with international illicit organize crime, and how these illegal practices are the main sources of their wealth. The novelist accentuates these aspects of many wealthy Nicaraguans in order to recreate the strong contrast that exists between the upper and lower sectors of the population. The opulence of the rich is juxtaposed with the miserable conditions in which the majority of the working classes live. The working 
class depicted in the novel seems to be a sector of the society that is crushed by poverty and the despair of hopelessness for a better economic future while many of the well-to-do do not seem to let go of an opportunity to increase their wealth, even if it means getting involved in an illegal act.

One of the primary purposes of the Revolution was to eradicate hunger and to guarantee that each individual member of the new society had the opportunity to study and earn a decent living. However, as shown in the following passage from the novel, in the post revolutionary/neo-liberal Nicaraguan society, many have to resource to heartbreaking measures in order to provide for themselves and their families:

Afuera se oía el golpe de las ruedas de un carretón que luego se detenía, y el ruido de un tacho al ser derribado. Eran los que buscaban tesoros en la basura, a veces familias enteras, que una vez expuestos los desperdicios en la acera seleccionaban botellas, envases plásticos, piezas de metal, juguetes viejos, y alguna vez hallaban restos de comida en las cajas de cartón de entrega a domicilio, panes de hamburguesas, huesos de pollo con algo de carne, rebanadas de pizza mordisqueadas (91-92).

The difference between the living conditions of the corrupt politicians and business entrepreneurs who maintain close ties with drug traffickers and the modest living conditions of the peasants who are force to migrate to the city of Managua in search of work is another example through which the novel shows a distinctive aspect of how the Revolutionary project did not achieved the goal of providing a better future for Nicaragua's poor. The reader can observe the inhuman conditions and poverty in which entire families live in neighborhoods newly formed on the banks of the heavily polluted 
Lago de Managua. One of these newly formed neighborhoods is el Barrio Domitila Lugo - mentioned in the novel—, with its "houses" made of tin and cardboard. The inhabitants of these new neighborhoods are families who migrated from the countryside to the capital in search of work in the textile factories located in the outskirts of Managua. The descriptions of these modest neighborhoods in the novel contrasts with that of the luxurious dwellings of politicians and businessmen located in neighborhoods such as Los Altos de Santo Domingo, where the lavish mansions with their capricious architectural details make the reader reflect that in one of the poorest countries in the continent this kind of constructions can only be made in many cases with the capital earning of illicit business.

Ramirez in his novel criticizes the bad economic condition in which the majority of the people live as a sign of a field revolutionary utopia because of mistakes and lack of consensuses among the revolutionary leaders through commentaries, like the ones I just noted. The commentaries made by the novelist also show his assessment of how the neocapital economic system is not doing much to favor the working class. People do not believe completely in the promises of reform made by the new governing system because, as the country's history has proved it, the ruling party of turn does very little to benefit the working class. The rich get richer and the poor get poorer.

\section{II.4.2.4. Other Discursive Forms in El cielo llora por mí}

I stated before that the socio-political discourse in Ramirez's novel is foregrounded by sires of sub-categories of discourses such as: the testimonial, the religious and the political/ideological. As per the testimonial discourse, I must first note 
that it has a long tradition in the Central American letters. Since the Cuban Revolution, Central American literature - the narrative in particular — has privileged the testimonial discourse, especially when it dealt with the relationship between history/reconstruction of memory and literature. Through the use of the testimonial discourse, accounts of the armed struggles in the fights against social injustice brought about by the dictatorial governments were themes foregrounded in Central American literature. However, with the socio-political changes that occurred in late 1980s and through the 1990s (i.e., the end of the civil wars and the signing of peace treaties and of international free trade agreements) in the region, the testimonial account is no longer at the center of the literary production and it has lost its primordial characteristic of being a discourse very close to factual accounts narrated by those who witness them. Instead, in the new literary paradigm the testimonial account has become a literary artifice by which fictional characters - inspired by historical figures — make reference to significant historical events. The testimonial account in the new literary form, instead of being used to evidence the human rights abuses and the violence and oppressions of the wars against the political regimes, is being used — among other things — in a parody form as a way to revisit the past in order to infer and comment the present state of affairs. The testimonial discourse in El cielo llora por mí, as I shall note in the following paragraphs, reflect the changes in the new literary paradigm.

The narration of the investigative process is fragmented throughout the novel by insertions of Morale's and Dixon's reminiscences of the time when they were intellectually and physically trained for the arm struggle — as I have already noted in the quotes from the novel that appear in section II. 2. The narrator also participates in this 
fragmentation by making references about the revolutionary times and its socio-economic system. A very significant mark that signal the precarious reality that many of the exrevolutionaries who never betrayed their revolutionary ethics, like Morales and Dixon, is Morales' old card a baby blue Lada ${ }^{21}$ — which contrast with the BMWs driven by Caupolican, Sheila Marenco and Gigo, and the luxurious SUVs and 4X4 trucks driven by the high government officials and other characters who have close ties to the illicit traffic of narcotics-like Black Bull and the Casanova brothers-; these vehicles stand as signs of wealth acquired by corruption and criminality. The Lada also represents a symbol of the revolutionary era when those close to the revolutionary movement received Ladas from the former Soviet Union as incentives for their participation in the reconstruction of the new Utopian Nicaraguan society. Now, the Lada, indicates the decrepitude of those Utopian dreams, like the car, the revolution is now a rundown idea:

... [Inspector Morales'] Lada azul celeste, sobreviviente de aquellos [revolutionary] tiempos (13).

... lucía bastante golpeado por la vida. El vidrio de la puerta del conductor se trababa a menudo, y el asiento de atrás, con los cojines reventados, parecía más bien un nido donde empollaran las gallinas;

${ }^{21}$ In the 1980 s, during the revolutionary years, Ladas were imported to Nicaragua from the former Soviet Union as part of an economic aid and trade package. They were vehicles that at first were utilized mainly by government officials and for the realization of daily tasks in the various national institutions. Consequently, they were past on as incentives to those members of the Sandinista party who demonstrated strong alliance and militancy. During the late 1980s and early 1990s, Ladas were seen in the streets of Managua and in other Nicaraguan major cities as taxis and family cars owned by loyal members of the Sandinista party. 
periódicos viejos, botellas vacías de cerveza, herramientas, un cargador de fusil, una lámpara de señales, se acumulaban en el piso. Los asientos delanteros, recalentados por el sol que ardía en el parabrisas quemaban al sentarse (36).

The revolutionary period alluded in the novel signals the gone by era when the Revolution was conceived as a democratic system and is represented by the uncorrupted actions of Morales, Dixon, Doña Sofia and Commissioner Umanzor Selva.

The religious discourse present in the novel is another way by which Ramirez comments with irony the social changes. In a humorous and carnavalesque manner, the main plot of Ramirez's novel is framed between two religious celebrations: 1) the welcoming of a statue of the Virgin of Fatima in the National Police Headquarters in Managua, which contrasts with the 1980's revolutionary socialist philosophy; and 2) the celebration of Saint Dominique of Guzman, the un-official patron saint of Managua, whose celebration is a carnavelesque rite that takes place during the first ten days of the month of August.

The scene of celebration in which the image of the Virgin is welcome into the police headquarters depicted at the beginning of the novel serves as a very strong sign of the changes that have occurred in Nicaraguan society with the change of government after the revolutionary years. The leaders of the governing institutions were all excombatants who were trained, in most cases, in Cuba or by Cuban revolutionaries and/or by soviet intellectuals during the Sandinista regime of the 1980s. Hence, they were well acquainted with Marxists and Leninist theories. As a matter of fact, the revolution was said to be a "Marxist-Leninist Revolution." Religious practices such as the one depicted 
at the beginning of the novel would not have been tolerated by Marxist-Leninist revolutionary leaders especially if the revered image stand as a sign of the communist theories and practices that sprung out of Russia during the first decades of the $20^{\text {th }}$ century. What is even more ironic in the novel is that the leading officials of the Nicaraguan National Police were men and women who got to such high positions within the institution because of their active participation in the revolution, as armed soldiers and later as social leaders. Their devotion to the Sandinista creed would not have allowed them to take part in religious rites like the one described below:

... Abajo, en el patio de estacionamiento, cantaban voces desafinadas entre un reventar de cohetes... Había pasado el mediodía, y la corona de la Virgen de Fátima relumbraba bajo el sol de la canícula que ya llegaba a su fin, mientras la imagen, en peregrinaje por toda Nicaragua, avanzaba entre dos vallas de policías, el anda [...] en hombros de los oficiales, hombres y mujeres, de la plana mayor. Los sones de la marcha festiva, ejecutada por la banda militar. . .

Todos, oficiales, policías de línea, agentes de investigación, secretarias, ordenanzas, afanadoras, estaban abajo junto a sus jefes recibiendo a la Virgen Peregrina, salvo doña Sofía Smith . . . ... Temprano había dejado sobre el escritorio del inspector Morales un memorándum, escrito con lápiz de grafito en el revés de una esquela de querimiento de abastos de oficina, que decía: Asunto: Actividad religiosa 
A: Compañero Artemio [pseudo-name of Inspector Morales during the pre-revolution period when he was an agent of the urban resistance in the liberal movement]

He recibido una citación para comparecer al recibimiento de la Virgen de Fátima, pero no cuenten con mi presencia. Me da vergüenza que compañeros revolucionarios se presten a una farsantería.

[Morales] [s]e incorporó al grupo de oficiales al momento en que la Virgen de Fátima era colocada en el altar erigido bajo las acacias, al pie de los ventanales, en medio del copioso rumor de los aplausos. La inspectora Padilla, directora de Recursos Humanos, las nalgas y los pechos rebosantes entallados dentro de su uniforme, recibió de manos del imponente capellán un folleto, se acercó al micrófono, dio las buenas tardes, y recitó escasa de aire y de Carrera Nuestra Señora vino a aparecer por tercera vez en Coda de Iría el 13 de Julio de 1917 a fin de revelar el Segundo secreto a los hermanitos pastores Lucia, Francisco y Jacinta que vieron de pronto un relámpago y apareció Ella vestida de blanco rodeada de luz resplandeciente y dijo vendrán guerras hambre persecución de la Iglesia causadas por Rusia y se hallara en peligro el Santo Padre pero si mi petición es acatada Rusia se convertirá y habrá paz si no Rusia difundirá el comunismo y los buenos serán martirizados . . . (12-13).

The excerpt above, besides marking the shift in the socio-political ideal in the Nicaraguan governing institution, it is also a mockery to the revolutionary ideals once held by many of the high-ranking police officials that are taking part in such ceremony. 
The revolution was inspired by the ideals of Carl Marx and the image of a true revolutionary had never been expected to take part in such religious observances. Furthermore, the image of the Virgin of Fatima is one of the most anti-communist symbols around the world. As cited above, it is believed that she appeared to the three shepherd Portuguese children to prevent the world of the "malice" that the communism preached by Russia would cause the world if nations around the world would accept communism.

De pronto, la Virgen de Fátima convertía en católicos practicantes a los leninistas más curtidos, tenía razón doña Sofía de quejarse. Larios, por ejemplo. No tenía pito que tocar aquí, su dependencia funcionaba fuera del área de la Plaza del Sol. Eterno secretario político del partido en la estructuras centrales de la Policía Sandinista, presidia los tribunales ideológicos que decidían la entrega de carnes de militancia tras un examen oral de suficiencia que podía tomar horas, con abundancia de aplazados, que por esos no podían aspirar a ascensos, y ese tribunal decidía también las expulsiones; los sentenciados con una expulsión de las filas partidarias nada tenían que hacer ya en la Policía (19).

The celebration of Saint Dominique of Guzman, which appears at the end of the novel, serves to reinforce the carnivalesque tone of the novel. The period of carnival in the Christian tradition - particularly in the Catholic Church—, as it is well known, represents the time prior to the Lenten period of the Liturgical year in the Church calendar. Lent begins six weeks directly before Easter. During this period, devoted Catholics would fast and would practice other pious or penitential practices. 
Traditionally during Lent, no parties or other celebrations were held, and people refrained from eating rich food and drinking. In the days before Lent, all rich food and drink had to be disposed of. The consumption of them was done in a giant party that involved the entire community. During the carnival season, participants let their hair down and enjoy life to the full. Masks and costumes help people take on a new identity and give them license to behave in ways they would not under usual circumstances. People also believed that it was a time when evil forces operate with strong forces. In Ramirez's novel, the events of the plot take place three days before one of the most significant times for celebration in the Nicaraguan religious calendar, the celebration of the feast of Saint Dominique of Guzman. The novel begins describing the events that occurred on Thursday, July $27^{\text {th }}$. The events of the novel occurred on the weekend before a time of celebration and throughout the novel the reader can observe how the inhabitants of Managua have already engaged themselves in the festivity. The celebration is marked very much so by many of the typifying characteristics of the tradition of carnival. The fact that the investigation of the mystery behind the disappearance of Sheila Marenco and the chase after the ring of drug traffickers in Nicaragua occurs during this time reinforces the idea that in El cielo llora por mi there is religious subtext that not only mocks everything that deals with any kind of ideological devotion, but also signals how the war against the international drug trade and the opportunity for corruption that it facilitates is seen as a conflict between good and evil.

The last subcategory of discursive form in El cielo llora por mi that I am going to discuss is the political/ideological discourse. In my analysis of Ramirez's novel I have discussed many of the social conditions under which it emerged. I have discussed 
specific traits that allude to the bad economic and moral state of present day Nicaragua, brought about by political corruption not only by the ruling government depicted in the novel, but also by many ex-Sandinistas who betrayed their revolutionary ethics; by the introduction of the new neo-capitalist society in the Central American region during the post-war period; and by the menace that the illicit drug traffic post on Nicaragua. One important factor that I must discussed regarding the political/ideological discourse present in El cielo llora por mi is the fact that the novel was written by one of the chief architects of the revolutionary estate in Nicaragua. ${ }^{22}$ In the novel, Ramirez's political views are marked by comments made by the main characters and the narrator in their retrospective view of the revolutionary era and in the descriptions of the social conditions of the Central American Nation.

${ }^{22}$ Sergio Ramirez in 1977 directed the group of the "Twelve," a group of prominent intellectuals, priests, businesspeople, and members of civil society who publicly supported the efforts of the Frente Sandinista de Liberación Nacional in their commitment to free Nicaragua from the Somoza dictatorship. After the triumph of the Revolution, in July of 1979, he became parte of the Junta de Gobierno de Reconstrucción Nacional - a governing body that ruled the Central American Nation until the 1984 elections. Ramirez serve in the Junta as the National Council of Education. In the 1984 elections, he was elected vice-president of Nicaragua as a running mate to Daniel Ortega. In 1990, the Ortega-Ramirez formula ran again for the presidency, but lost power to the UNO coalition headed by Violeta Barrios de Chamorro. Ramirez continued to serve as one of the leaders of the Sandinista party in the National Assembly, but because of difference political opinions with other Sandinista leaders, such as Daniel Ortega, he left the FSLN and along with other dissident leaders of the Sandinista party who disagreed with Ortega's faction to form the Movimiento de Renovación Sandinista (MRS). A political party that seeks to bring about social changes in Nicaragua through a philosophical code inspired by those of the early years of the Sandinista movement. In 1996 Ramirez ran for the presidency on the MRS ticket, but lost the elections. Since then, he has retired from the political arena, to pursue his passion for literature, but he still remains a strong critical voice against the Sandinista faction lead by Ortega. 
This political discourse is made evident in the novel among other things by Ramirez's faith in the common, ordinary people of Nicaragua. As believed by the Sandinista leaders during the years leading to the Revolution, the common everyday people of the country have the power and the strength to accomplish the social reforms in order to gain the democracy much desired by many Nicaraguans. What are needed to bring about the much desire changes are ethical leaders who would turn away from corruption and greed. Characters like Dona Sofia, Dixon, La Monja and Commissioner Selva are representations of those individuals who by working together can bring about social changes and justice, as they do in the novel. The collaboration of these individuals and their faith in justice and integrity are the reasons why at the end of the novel the criminals are caught and force to face justice.

The main characters' and narrator's comments point toward Ramirez displeasure of the ruling government who are described as good for nothing socialites and corrupt individual, always away from their primary duties in order to attempt some sort of festivity, as noted in the following quote:

-El presidente está inaugurando una super gasolinera en Villa Fontanadijo el comisionado Selva.

-¿Cuántas gasolineras ha inaugurado ya este año? - preguntó el inspector Morales.

-No llevo esa cuenta-respondió el comisionado Selva, un tanto hosco. -¿Y qué está haciendo allí el primer comisionado?-pregunto el inspector Morales. 
-Me imagino que lo citó el ministro, está también todo el gabineterespondió el comisionado Selva (23).

The above dialogue alludes to the lack of work ethics of the political leaders like the president and his cabinet members who engage their time in celebrations of very little if at all importance for the Nicaraguan people, such as the opening of a gas station, when they should be involved in making transcendental decisions for the run-down country. The excerpt of the novel above and the one that follows locate the plot of the novel in a very specific historical time frame in Nicaragua, and Ramirez in the novel makes every effort to incorporate his political critical views of the ruling government. The events depicted in the novel take place during the presidency of Arnoldo Aleman (1997-2002). ${ }^{23}$ The following statement in the novel collaborates this inference:

${ }^{23}$ Aleman is a very controversial Nicaraguan politician, before becoming the $81^{\text {st }}$ President of Nicaragua he was a lawyer, an official in govermment of Anastasio Somoza Debayle. He was a political prisioner during the revolution, a political exile, and a prominent businessman after returning to Nicaragua in the late 1980s from his exile in the United States. In the early 1990s, he became Mayor of Managua. He was popular due to his urban renewal projects that helped spruce up the city of Managua, severely damaged and never rebuilt after the 1972. In 1995, he resigned from his position as Mayor of Managua to run for the presidency against a very popular Daniel Ortega. He won the 1997 elections by a $48 \%$ of the vote to Ortega's $40 \%$. He is known as "El Gordo" ("The Fat Man") for his obese figure.

Aleman was successful in promoting economic recovery with reduced inflation and growth of GDP. During his precidency, foreign investment grew, which helped to improve Nicaragua's infrastructure. Under his slogan of "Obras, no palabras!" ("Actions, not words)", Aleman directed a comprehensive reconstruction of the roadway system throughout Nicaragua. During the 1980s, roads throughout the country had deteriorated to the point that many were little more than sparsely paved dirt trails. Aleman also created a program to build schools throughout Nicaragua in some of the poorest regions. His presidency is also remembered as one of the most corrupt in the Central American region. He ranked as one of the world's 10 most corrupt leaders ever by Transparency International (he is the $9^{\text {th }}$ in the list). The allegations of corruption emerged after Enrique Bolaños succeeded him in the presidency (Bolaño was Aleman's Vicepresident). The allegations claimed that Aleman was concealing massive corruption in 
El retrato del obeso presidente, con la banda azul y blanco terciada al pecho, se hallaba colocado en la pared detrás del escritorio del comisionado Selva, al lado de la bandera de Nicaragua ensartada por el asta en un pedestal, como en todos los despachos de los altos mandos de la Policía (23).

The novel alludes to the bad economic condition in which the majority of the people lived during those years when the free market society was established in Nicaragua. ${ }^{24}$ The narrative also shows the discontent of the working class that has not

his administration. A number of Aleman's close family members (a brother, a sister, and even his daughter and her husband), as well as close friends and central figures of his cabinet were accused and many charged with corruption charges. Aleman himself was charged and sentence to serve a 20 -year prison term for corruption charges that included money laundering and embezzlement, among others.

A political agreement (known in Nicaragua as "el pacto") between Aleman-who was heavily supported by his party's leader, many of them officials who served in Bolaños presidency and Daniel Ortega, who planned to run for the presidency for a forth time in 2006-facilitated the conditions by which a Nicaraguan Supreme Court overturned the 20 -year corruption sentence. The agreement between the two political forces lead to a constitutional reform and to the distribution of the institutions of the state in proportion to the power managed by the two main Nicaraguan political parties, the Partido Liberal Constitucional (PLC) and the Frente Sandinista de Liberacion Nacional (FSLN).

${ }^{24}$ The insertion of the new global economy in contemporary Nicaragua is alluded in the novel by the mentioning of: multi-national corporations such as the telecommunications company "Movistar," the big advertisement signs that light the streets of Managua at night (72), the springing of "super-gasolineras (gas stations, 118) with convenience stores, cable TV ("trecientos cordobas mensuales por el servicio de cable, un desperdicio... 169), the multiplex cinemas (with the super-size Sodas and popcorn and the powerful air-conditioning system 121), and the new shopping malls like "Metrocentro" and "Galerias Santo Domingos"-through which hallways-“desfil[an] familias enteras lledadas de los barrios lejanos en los buses de ruta. [Donde] [p]asarian la tarde admirando las vitrinas de las tiendas desde las que emanaba, al correrse las puertas automaticas, un frescor de país extranjero" (227). 
enjoyed the benefits of this system. Ramirez's mistrust of the new political leaders and of the new economic system is seen in the novel by the following dialogue between inspector Morales and a nurse whom he helps escape the retaliation of the police during the strike on his way to his office; it also depict the popularity that Daniel Ortega still enjoyed at the time among the working class: “- Cuando ganemos las elecciones te vamos a dar un ascenso — le dijo ella, sonriente por fin. - ¿Cuando ganemos quienes? — pregunto el inspector Morales. -El Frente Sandinista—respondió ella—, en la próxima vuelva Daniel (51).

The novel highlights how the Nicaraguan people do not believe completely in the promises of reform made by the new governing system because they witness how this system only benefits the rich. The novelist also comments how in Nicaraguan the rich politicians seem to be getting richer by earning high salaries (known in Nicaragua as "Mega-salarios") and the poor working class must work harder to pay the high cost of living with miserable salaries, and how national institutions - like the National Policedo not have the proper equipment to conduct their daily business.

The misdistribution of funds is presented in the novel by the allusion that while first Commissioner Canda throws a very pompous party for his 15 -year old daughter and takes her on vacation to Disneyworld (171), inspectors Morales and Dixon have to work their case with very limited resources at times borrowing money from relatives to pay for gasoline used to transport themselves from one place to another during the police investigation. Individuals who have very close links to the governing party and occupy high-ranking offices receive "Mega-salaries," and are able to enjoy a very opulent life style. The comments made by the narrator and the characters in the novel seem to point 
how the lack of proper distribution of public funds is one of the reasons why the country is in bad economic state. They serve as sings of the novelist's political discourse within the novel.

Through the incorporation of this heteroglossia or plurality of discourses, Ramirez in his novel establishes the insidious sense of corruption and decay prevalent throughout the novel, and the disillusionment with the utopian projects of the Revolution that were not reached because of the lack of strong and ethical leaders. Ramirez is capable of recreating the poor current state of affairs in Nicaragua's social realm, with this juxtaposition of multiple discourses in the novel. However, the novelist vision for Nicaragua's future is not at all pessimistic. In the novel, Ramirez's faith in the people of Nicaragua as the architects of a better tomorrow — as it was envisioned during the revolutionary years - is expressed through this amalgam of discursive forms. The inference can be seen in the last comments made by the characters of the novel and its narrator:

El santo [Saint Dominique] estaba ya a la vista, casi imperceptible en la cúspide de su peana de flores, con su acompañamiento de promesantes entregados al desenfreno del baile, y sometido al zangoloteo de la cofradía de cargadores. El jolgorio era la penitencia...

El inspector Morales había leído ese folleto [La dualidad de Santo Domingo de Guzmán como deidad desde el punto de vista leninista, escrito por el Profeta] en el encierro clandestino de León, porque estaba entre los materiales de estudio de la célula. Pese a siglos de transmutaciones, Santo Domingo de Guzmán, fraile fundador del Santo 
Oficio de la Inquisición, seguía encarnando en la mentalidad popular mágica a Xolotl, el dios con cabeza de perro Bermejo que guiaba a los muertos entre las tinieblas en su viaje a Mictlán, la región ignorada del más allá. Así los probaban el perro echado a los pies de la imagen del santo, y el barco en que era subido a su entrada a Managua, recuerdo de la canoa en que Xolotl iba en procesión por las aguas del lago Xolotlán, bautizado en su nombre. Y la multitud de bailantes enardecidos no era más que una demostración de la rebeldía ancestral indígena en contra la dominación del colonizador español, que ahora se expresaba en contra del sistema de explotación capitalista y del imperialismo.

-Santo Domingo y el imperialismo - dijo el inspector Palacios-. Para cuadrado, el Profeta. ¿Qué tenían que ver las dos cosas?

-Lo mismo que tiene que ver la Virgen de Fátima con la Policía Nacional—dijo desde atrás dona Sofía (287-290).

\section{II.4.3. Other Postmodern Structural Aspects of El cielo llora por mí}

I have concentrated my analysis of Ramirez's novel on the literary technical resources utilized by the novelist in order to conceive a mixture of fact and fiction, how he is able to create fictional characters whose lives are linked to historical accounts in the previous sections. I also discussed how Ramirez employs multiple discourses within the novel that evident Nicaragua's present day reality through some of the themes presented in the novel. In this section, I will focus my discussion of Ramirez's novel and talk about specific structural mechanisms present in the novel that indicate its close connection to 
postmodernist fiction writing. In his theorization of postmodern fiction Brian McHale talks about the actual form of the book. He maintains that postmodernist texts utilize the actual book for their own benefit. His argument is based on the idea that the structure of the literary work rests on the physical book and its typography. El cielo llora por mí seems to show very little evidences of the experimental aspects of postmodern typography because the way events are presented in the plot, at a first glance, might seem to distance the novel from the ludic experimentation of the postmodern deconstructive game. Ramirez constructs his novel using the classic model of the detective genre as I shall discuss in the following section, but he does not adhere himself to the formulaic detective plot prescribed and much abused by detective novelists of the 1930s and 1940s, the "golden age" of the detective novel. I also must point out that while in more experimental Central American detective novels—such as Rafale Menjivar's De vez en cuando la muerte and Horacio Castellanos Moya's Baile con serpientes or Ramon Fonseca Mora's El desenterrador ${ }^{25}$ - the perception of reality presented does not always follows a logical order, in Ramirez's novel reality and the vision of reality that the characters and narrator seem to match the rational world.

\section{II.4.3.1. El cielo llora por mí, the Detective Narrative and Postmodernity}

Sergio Ramirez's El cielo llora por mi exhibits multiple aspects of the detective narrative, most specifically it adhere itself to that literary tradition of the detective genre that incorporates a poignant social criticism and that is known as the noir narrative as I

${ }^{25}$ The last novel in the list will be discussed in the last chapters of this dissertation. 
have discussed in the previous sections of this chapter. Even though Ramirez's novel seems to follow the classical organization of the crime novel because it employs the assumptions, the logic and methods of detective fiction, the novel does not seem to finish with the traditional ending where the mystery is solved and order is restored. In the first part of the formulaic detective novel, the crime and the sleuth are introduced. In Ramirez's novel, these two elements are introduced in the first chapter. The reader meets the main characters, Morales, doña Sofia and Dixon, and the disclosure of the crime and mystery to be solved hooks the reader. Dixon informs Morales of the finding of a luxury yacht that was abandoned on the night of July $25^{\text {th }}$ in the backs of Pearls Lagoon in Bluefields, near the community of Raitipura. As per the information that Morales receives, in the floor of the yacht there were traces of blood and of cocaine. The presence of the blood and of cocaine will deploy the investigation of whom the blood belongs to and to what extend these traces of cocaine are linked to the traffic of narcotics in Nicaragua. In the second section of Ramirez's novel, which corresponds to chapters two to seventeen — and that matches with the traditional formula for detective fiction writing - the sleuths embark in the path toward solving the mystery; the direction of the investigation toward a conclusion is set forth by possible hypothesis base on the evidence found and logically analysed. Doña Sofia plays an integral part in the investigation by proposing logical assumptions that bring the mystery to its final resolution. The third section of the formulaic mystery novel is characterized by a change of focus and scope of the investigation. In the story, this is the pivotal point where it becomes evident that the detective was on the wrong track, or something unexpected occurs, such as the appearance of another dead body or the death of a major character, or perhaps the 
discovery of new evidence. The story is taken into a new direction. In El cielo llora por $m i$, this section corresponds to chapters $18-23$. One major event that occurs in this particular block of the novel is the death of Inspector Dixon, which is the event that motivates the final police operative that would bring the criminals to justice. Chapters 24 and 25 in the novel represent the solution of the investigation. In Chapter 24, the night of Lord Dixon's wake, after paying his respects to his dear friend, Morales pays a visit to the casino "Josephine's" and in a dramatic confrontation between the sleuth and the perpetrators Morales assure the criminals that they will pay for their offence. Thus, the investigation of the mystery, which is also the end of the novel, concludes with the capturing and deportation of the criminals. At a first glance, it seems that these events are the solution to the mystery presented in the novel and that by capturing the criminal order is restored; however, the novel also points out that in the business of trafficking illegal drugs even high government officials are beneficiaries.

Even though the structure of Ramirez's novel follows the formulaic recipe of the detective novel, I must also mention that Ramirez's choice of the detective genre to recreate a historical moment in Nicaragua's history and to recreate the violence, real aspects of the human psyche and all the aspects of the contemporary society of the Central American nation in the novel shows his attempt to produce postmodern noir narrative. Let's not forget that postmodernist artist cross the boundaries between various disciplines and movements, and must particularly, between high and popular mass culture. They are fascinated by artistic productions that traditionally have been marginalized or ignored by the controlling elite. Therefore, the postmodern artist often incorporate elements of popular culture such as the kitsch, the TV series, Hollywood B- 
films, para-literature and sub-literary genres such as the romance, mystery, science fiction and the narrative of fantasy into their repertoire. These artist recuperate popular culture in the urge to adapt the mechanisms of narrative representation to the current postmodern condition.

Several critics have noted that there is a tendency in postmodern fiction to incorporate and use aspects of formulaic narratives such as the detective story. ${ }^{26}$ Ramirez shares this tendency in El cielo llora por mí. The plot of the novel is deployed by detectives - professionals and amateurs—-who engage themselves in a detective search for the answer to a mystery. The use of the detective form in Ramirez's novel instances the general process of embracing popular forms that critics see as a typifying aspect of postmodern cultural expression. In this process, what have been referred to as "marginal art forms" or sub-genres — such as the detective story, the mystery, the thriller, the science fiction and the narrative of fantasy — are brought into the dominant literary main stream. To such process Theo D'haen refers as a "general flooding in of popular [sub]genres into the center of the literary system in Postmodernism" (1987:161).

The significance of the detective narrative in postmodern fiction lies in its inversion of the philosophical implications of the popular form. The detective story has been well known for the defying characteristic of the search for a solution to an enigma. In postmodern fiction, this narrative is employed in order to foreground the impossibility

${ }^{26}$ See Michael Holquist "Whodunit and Other Questions: Metaphysical Detective Stories in Postwar Fiction" (1971), William V. Spanos "The Detective and the Boundary: Some Notes on the Postmodern Literary Imagination" (1972), Frank Kermode "Novel and Narrative" (1974), John G. Cawelti Adventure, Mystery, and Romance: Formula Stories as Art and Popular Culture (1976), and Stefano Tani The Dommed Detective (1984). 
of certainty. Thus, depicting postmodernism's epistemological and ontological doubt. In its postmodern use, in which the search is frustrated, this kind of narrative focuses attention on the coded nature of the world, allowing novels to be organized around signs which function as clues, but only indeterminate clues, that finally become the point rather than lead to it. In conventional detective fiction, the story starts out with a mystery - the loss of order—and concludes with an explanation — the restoration of order. ${ }^{27}$ P.D. James, the English mystery writer, feels that the detective genre "reaffirms the reader's hope that there is a law both divine and public, that there are explanations" (Critchfield 1990 272). As John G. Cawelti writes, "the classical detective formula is perhaps the most effective fictional structure yet devised for creating the illusion of rational control over the mysteries of life" (1976 137). However, the postmodernist period has produced what Michael Hoquist calls the "metaphysical" detective story, which employs the assumptions and methods of detective fiction, but does not incorporate the ultimate logic of its conclusion: in the end the mystery is not solved, and order is not restored. The effect offered by the metaphysical detective story is "strangeness, a strangeness which more often than not is the result of jumbling the well-known patterns of classical detective stories. Instead of reassuring, they disturb" (1971 173). As Patricia Waugh observes, "in the postmodern period the detective plot is ... used to express not order but the irrationality of both the surface of the world and of its deep structures" (1984).

${ }^{27}$ Detective stories from the 1930s and 1940s, the "golden age" of the detective novel, can be seen as the period in which the conventional form was most prolific. By the golden age, "generally acknowledged 'rules' had evolved, formulas which required logic and fair play on the part of the author. The idea was to present a mystery puzzle to be solved, and the reader was 'invited' to make use of the clues in order to reach a solution” (Cuddon 1991 232). 
In the use of the detective plot, El cielo llora por mi highlights its postmodernity. At the same time, the novel foreground significant cultural distinctions of the noir genre that contrast with the conventions and assumptions of the traditional forms. Anthony Hilfer writing about the traditional English and American detective fiction states that: ... the English detective reassures us of an ultimate rationality, a "benevolent and knowable universe," "world that can be interpreted by human reason, embodied in the superior intellect of the detective." While there are puzzles solved by the American detective, his real function is to validate the American myth of personal integrity, absolute individualism and stoic self-control. His exemplary role is not to explain the world but to survive it (1990 7).

The sort of national variations that Hilfer identifies are an indication of important differences in the way the world is approached in the two cultures, the English and American. These kinds of generally persisting distinctions also inform the postmodern sensibility of El cielo llora por mi. ${ }^{28}$

${ }^{28}$ The variant traditions of the detective genre are themselves symptomatic of a much-argued divergence between the English and the American novel -the English realist novel and the American romance. These differences, for example, are pointed out by the American critic Richard Chase in The American Novel and Its Tradition (1957). The central concept of Chase's study is the distinction between English and American fiction. While social realism is considered typical of English writing, the American romance-novel is, in contrast, characterized by its "non-social" anti-realism and shows a preference for the symbolic. For Chase, the English novel, which "gives the impression of absorbing all extremes, ... [u]sually... has been realistic or, in the philosophical sense of the word, "naturalistic." American novels, however, show that "the American imagination... has been stirred... by the aesthetic possibilities of radical forms of alienation, contradiction, and disorder." (2) Furthermore, Chase makes another crucial 
As detectives Morales and Dixon search for the clues to solve the mystery of the disappearance of Sheila Marenco and the enigmatic finding of the abandon yacht, they make an attempt to recover-or "reclaim"- a once known world which seems to hold the key to the contemporary state of affairs in Nicaragua. That is to say, in their investigation the detectives search not only to discover the clues to solve the enigma, but also recover the memories of the recent revolutionary past in order to comprehend the present day state of affairs in the Central American country. They go out to discover signs of the inheritance of the revolutionary times in the present world that surround them. The inquiry into the past is ever forwards throughout the novel and serves as a way to illustrate the mistakes made by many of the leaders of the revolution who became corrupted and abused their power for their own personal interest. The plot in El cielo llora por mi delineates a retreat into the past that has lead to the present. The reconstruction of the memory of the period of political upheaval through the isthmus is a very typifying aspect of the new contemporary fiction being produced throughout the isthmus, as I shall outline once I study the other four novels that occupy this study. The way in which El cielo llora por mí ends also exhibits another element of Ramirez's novel distance itself from the formulaic detective novel and also helps demonstrate one more aspect of the postmodern fashion of the detective novel and its resistance to closure. The traditional detective novel, as stated before, ends with the solution to the mystery and

distinction: "The English novel," he writes, "has been a kind of imperial enterprise, an appropriation of reality with the high purpose of bringing order to disorder. By contrast... the American novel has usually seemed content to explore, ... merely to discover a new place and a new state of mind." (4-5) These critical constructions in these literary productions highlight a consistent underlying cultural difference. 
with the restoration of order. Ramirez's novel ends without a final resolution for either the characters or the readers. The reader can perceive its ambiguous ending as he or she read through the final pages of the novel. The reader never knows who actually killed Sheila Marenco. One do not know if it was Caupolican or Black Bull the actual assassin. One is also left wondering if Caupolican helped Sheila Marenco still money from the drug-kingpin for which she worked. Must importantly, at the end of the novel, the reader is left wanting to discover how far implicated are the political leaders in the international illicit drugs trafficking. I must agree with Patricia Waugh — as state before—-that writers to communicate the irrationality of both the perceivable and unperceivable structures of contemporary society are using the new form of the detective narrative.

\section{II.4.3.2. Referenciality, a Postmodern Element in El cielo llora por mí}

The use of subtitles that make reference to elements of popular culture in El cielo llora por mi cleverly summarize the events depicted in each of the sections and at times also allude to the postmodernist element of sel-referenciality. They exhibit Ramirez's attempt to construct postmodern literature. The novel is divided in 25 chapters or sections and each one of them is titled by short phrases that remind the reader of aspects of popular culture. Chapter Title's like: "Adiós Reyna del Cielo," "El cantor de tangos," "La Golden Mermaid," "Salvaje y agerrido" and even the title of the book which is also a title of one of the chapters - chapter 20 - are constant reminders of popular culture.

"Adiós Reyna del Cielo" is the title of a traditional song typically sang during the festivities of the Virgin Mary in Nicaragua. "El cantor de tangos" alludes to Tomas Elloy Martinez novel. "La Golden Mermaid" is the name of the Casanova's water vessel 
in which he transports his contrabands and it alludes to the German fairy tale attributed to the Brothers Grimm and that in the repertoire of traditional popular culture has become a name for a water vessel such as in the popular series of stories "Pirates of the Caribbean." "Salvaje y agerrido" is the beginning phrase of the third verse in Ruben Dario's poem "Caupolican." Finally, the title of chapter 25 and of the book is a clear reference to the popular saying in the Hispanic world "El cielo llora" which is use to describe a particular sad moment in someone's life when even the sky turns grey and rain starts to fall. In their theorization of postmodernity, Hassan and McHale recuperate all of the popular artistic forms that challenge the institutionalized high arts and we see aspect of postmodernity in Ramirez's El cielo llora por mí.

Another particular aspect of postmodern literature present in Ramirez's novel and alluded by one of the chapters' title is that of self-reflexivity. In El cielo llora por mí, this feature signals the self-conscious nature of the novel. According to Santiago JuanNavarro "among the specular devices by which a novel can be made to mirror itself, critics have paid special attention to the mise en abyme" (1995 39). Lucien Dällenbach in Le Récit Speculair (1977) defines Mise en abyme as "any internal mirror that reflects the whole of the narrative by simple, repeated or 'specious' (or paradoxical duplication)" (36). Dällenbach also explains the three different types of duplications that can be present in an artistic production: 1) the simple duplication which occurs when a sequence maintains a similarity with the work that encloses - that is to say that an object contains an image of the object—; 2) infinite duplication which can be induced by an image reflected by two parallel mirrors; and 3) the paradoxical duplication which consist of a sequence that seems to enclose the work that encloses it in an endless spiral. 
Furthermore, in his categorizing of the multiple types of duplication, Dällenbach establishes four structural levels of reflection that can be present in an artistic production. These levels of reflection may or may not appear in their most pure forms, but most often overlap. The first one of these levels of reflection is the fictional mise en abyme: this is the "intertextual résumé or quotation of the content of a work" (1977 55). We can state that this occurs when in a work of fiction there is a gathering of a set of events or motifs already mentioned summarize and/or anticipate a synthesis of the events about to occur. The second level is that of the mise en abyme of the enunciation: it presents in the plot of the narrative the producer or receiver of the work; it reveals the artistic production or reception; and manifests the context that determines the production and/or reception of the work. The third level is the mise en abyme of the code: it signals the way in which the text functions. The mise en abyme reveals multiple signs that direct the reading as it is designed to be read and establishes a discourse that suggests the "indication of the purpose assigned to the book by the author or by the book itself" (1977 99). The last of these levels of mise en abyme proposed by Dällenbach is the transcendental mise en abyme or the fiction of origin it is that which reflects "what simultaneously originates, motivates, institutes, and unifies" the literary work and determines in advance what makes the narrative possible. In addition, it implies the question of how a narrative conceives its relationship to mimesis and truth (1977 101). The postulates regarding a narrative's self-representation mentioned above help guide the understanding of the reflexive aspects of a postmodern novel.

In my analisis, I am able to identify two specific examples that signal the selfreflexivity of El cielo llora por mí. The first one is established by doña Sofia's reading 
habit of the detective novel. Early in the novel the reader becomes acquainted with doña Sofia's clever way to weave together threads of the investigation and construct hypothesis of the motives and actions of the criminals. Her detective skills are a product of not only her wit but also her passion for the detective literature. Doña Sofia's fascination for the detective genre can be seen in the following dialogue that occurs in one of the early stages of the investigation in which Lord Dixon, Morales and doña Sofia talk about the finding of a novel in the abandon yacht:

-A quién le importan las novelas—dijo doña Sofía.

-A usted, que las vive leyendo—respondió el inspector Morales.

-¿A usted le consta? - dijo doña Sofía, con voz encrestada.

-Claro que me consta — dijo el inspector Morales - Vaya a traerme ese libro con pasta de Jesucristo predicando en el huerto, con el que anda de arriba para abajo, y veamos sino es una novela de detectives.

-Mientras los traficantes de droga andan sueltos, usted tiene tiempo para espiarme a mi-dijo doña Sofía.

-Diga la verdad—dijo Lord Dixon—. ¿Cuántas de esas novelas se lee al día?

-A veces no me da el tiempo para terminar ni una—dijo doña Sofía -. ¿Usted cree que aquí vivo de vaga?

¿¿Y dónde las consigue, si se puede saber?—preguntó Lord Dixon.

-Las alquilo en el Mercado Oriental— dijo doña Sofía -. ¿Acaso me ajusta la miseria que gano para comprarlas? Y tampoco crea que hay mucha 
variedad, a veces repaso la misma, y si las meto dentro de los forros del libro de himnos, es para que no acaben de descuadernarse (31-32). Following Dällenbach categories of duplication and of the myse en abyme, I observe that the explicit reference to the choice of novels read by doña Sofia serve as a signal within the novel that confirms a reflexive component of the novel. Just as Dällenbach establishes the aspect of the "simple duplication" I observe that the detective novel that doña Sofia has at the moment that the above conversation took place is a physical object that reflex Ramirez's novel. The reference to this type of fiction early in the novel establishes the novelist's intention to mimic the noir tradition. In addition, the novel found in the yacht is Tomas Eloy Martinez's novel, El cantor de tangos. This other literary reference also signals a form of reflexivity within El cielo llora por mí.

El cantor de tango is the story of a Bruno Cadogan who is an American writing a dissertation on Jorge Luis Borges' view of the tango. In his research, Bruno finds out that in Buenos Aires there is a tango singer named Julio Martel, who sings the type of tangos that Borges would have heard in his youth. Bruno embarks in an investigative search throughout the city of Buenos Aires and seeks the singer in the hope to meet him and hear him sing, for it seems that no recordings of his exist. Bruno's search for the tango singer, leads him into a labyrinthine wandering through time and space where the reconstruction of the memory plays an important role. Martel decided to abandon a professional career in order to mark off places and events throughout the Argentinian capital that hold particular meaning for him. In his quest, Bruno sees himself in the middle of a labyrinth that is the city of Buenos Aires and the chaos of trying to survive the national economic crisis of the early years of the $21^{\text {st }}$ century. Just like Eloy Martinez 
in his novel, Ramirez in his makes use of the element of the quest and the wandering through the streets of a contemporary Latin-American city—in Ramirez's novel this city is Managua and the wonderer is Inspector Morales. Both character search for clues that would bring them closer to the individuals they are looking for, but most importantly in both novels we note how their authors not only celebrate the two Latin American cities and their lengthy and tragic histories, but also the cultural crisis that contemporary times and postmodernity has imposed in the individual. The above literary allusions serve as reflexive markers that not only signal the way El cielo llora por mí is constructed as a detective novel, but also as an instrument of self-reflection by which the ex-revolutionary figure can attempt to find answers to the chaotic state that the new economic system has imposed in the Central American nation. Thus, I can conclude that the reflexive aspects within Ramirez's novel is established by the element of the search inherited from the noir narrative and exemplify a form of overlapping of the "mise en abyme of the code" and of the "transcendental mise en abyme"- to use Dällenbach's terminology.

\section{5. Conclusion}

Sergio Ramirez's literary work is characterized by a historical reflection on Nicaragua's recent past. His literature also foregrounds the representation of paralinguistic signs of the socio-political changes of the last one hundred years in the Central American nation. Ramirez's narrative project is a literature that significantly projects the different trends in political, historical and aesthetic discourses in the multiple processes of social change through Latin America. His fiction highlights the complex relationships between extra-literary reality and the narrative representation. In my 
analysis of Ramirez's El cielo llora por mí, I have noted how through the use of irony and of a pungent social criticism, typical of the noir narrative, and the use of metafictional structure in a paradoxical combination of historical facts and fiction this Central American novelist not only recreates the historical past, but also the chaotic contemporary times in his artistic production. In this chapter, I have attempted to demonstrate how in this new literary paradigm Ramirez invariably blur elements of fact and fiction within his novel and by doing so he contributes towards the thorough skepticism and the lack of any definitive sense of coherent certainty by presenting themes that reflect the insidious sense of corruption, decay and disillusionment brought about by criminal and unjust acts. Thus, Sergio Ramirez in his novel, by making use of parody and "historiographic metafiction," establishes a reflection on the relationship between history, present day reality and fiction. Therefore, it can be stated that El cielo llora por $m i$ is a perfect example of the new Central American noir novel that incorporates the new practices of postmodern literary fiction writing. 


\section{CHAPTER III}

THE CENTRAL AMERICAN LITERARY TRADITION OF VIOLENCE IN DANTE LIANO'S AND HORACIO CASTELLANO MOYA'S NARRATIVE

\section{PRODUCTION}

\section{III.1. Violence in Central American Letters}

The element of violence in Latin American literature has always been a constant element in its historiography. Latin American writers throughout the multiple phases of the American literary history have always used the literary production as a vehicle to denounce violence, most specifically political violence. Historical fiction, testimonial narrative and politically committed poetry are but a few examples through which violence has come to be regarded as an aesthetic form in Latin American letters. Central American contemporary literature, as I have noted previously, has become well known for denouncing the political violence lived in the region during the last four decades of the $20^{\text {th }}$ century. Mackenbach and Ortiz Wallner on the topic of violence in the Latin American literary project have noted that:

La violencia es asumida desde las ciencias sociales en su múltiple dimensión social, política, económica y cultural como parte estructural de la historia latino y centroamericana. Así, los estudios de la cultura, de la historia y de la literatura constatan la persistencia de manifestaciones estética de la violencia a lo largo de diversas fases de la historia literaria latino y centroamericana, en donde es incluso posible hablar de un dominio de la violencia como manifestación estética. (82) 
The Central American literary production of the 1970s and 1980s became an instrument of inquiry and analysis of the revolutionary projects. The narrative production in countries like El Salvador, Guatemala and Nicaragua, were device through which the violence of the civil wars was being discussed and analysed. Hector Leyva has noted that in Central American literature produced during this historical period the element of violence is a constant in the three most representative literary tendencies that characterize this epoch: the novel written by guerrilla members, the testimonial narrative written by civilians affected by the armed struggles and the novels written by political dissidents; thus, this literary paradigm foregrounds the testimonial narrative (19).

Many writers took the concept of violence during the years of armed struggle in Central America as an instrument that helped exposed the political oppression of authoritarian governments and the military forces. However, in the years after the signing of the peace agreement in the region - the early years of the 1990s - violence in Central American letters is no longer conceived as an instrument of ideology against social repression. Instead, in the most resent literary productions that come from the isthmus, violence stands as the main dynamic for criminal perpetrators to obtain money in order to survive in the very harsh economic conditions in societies devastated by a civil wars and armed struggles. In the following sections of this chapter of my dissertation, I will focus my analysis of the recreation of the theme of violence in three Central American novels: El hombre de Montserrat, by Dante Liano; La diabla en el espejo and El arma en el hombre by Horacio Castellanos Moya. The analyses of these novels will highlight the shift in the conceptualization of the element of violence in these two historical periods. 


\section{III.2. History and Reflexivity in Dante Liano's Literary Project}

The Guatemala born writer Dante Liano belongs to that generation of Latin American writers who began their literary career after the "Boom" period in the Hispanic letters. Liano was born in 1948 and began his literary career in the late 1970s after earning a doctoral degree in literature from the University of Florence, Italy in 1977. His first work of fiction is Jornada y otros cuentos (1978), and eleven years later he publishes his first novel El lugar de su quietud (1989), followed by El hombre de Montserrat (1994) and El misterio de San Andrés (1996), just to name a few of his literary work.

Dante Liano's literary production is characterized by the incorporation of aspects of the, socio political situation in Guatemala's recent history. Like Sergio Ramirez's, Liano's narrative is a literature that foreground the multiple tendencies in the political, historical and esthetic trends in Central American. Liano transfers the extra-literary reality to the fictional work in his writing. One of the ways in which the Guatemalan writer accomplishes the task of representing the paralinguistic signs of the social circumstances of his country is by incorporating themes of social injustice brought about the political turmoil lived in Guatemala from the 1940s to the present day. Among the long list of themes found in Liano's fictional work we can mention: racism, discrimination, authoritarianism, expropriation of land, military abuse and death. Liano's writing is an amalgam of irony, humor and social protest. He makes use of experimental techniques like carnivalism, parody, metatextuality and metafiction to recreate the social conditions of contemporary Guatemala. María Annabely Asencio has stated that: "Dante trasluce la capacidad de su denuncia social por medio de un lenguaje colloquial, poético y a ratos 
escatológico. Estas formas de expression conllevan un profundo mensaje en la caracterización de sus personajes" (vi).

Earlier in this dissertation I noted how contemporary Central American narrative is a fusion of styles and discourses and that is a fiction still linked to the testimonial account, to the historical, the political, the mystery and the thriller literature. I also noted that it is a literature that forefront the artistic manifestations depicting the persistent war against social injustice. The element of violence in the Central American literary production is marked by the unjust distribution of the power of acquisition and is one of its main themes. Furthermore, I analyzed how Sergio Ramirez's literary project reflects the above mentioned struggle for social injustice, and I established that the Nicaraguan born writer does so by making use of the imaginative space as the sphere to (re)invent, to reinterpret the past, and to show its conflicting relationship with the present day reality of its country. ${ }^{29}$

All of the above mentioned characteristics present in Sergio Ramirez's literary project are also found in Dante Liano's fictional work. In his 1996 novel El misterio de San Andrés, for example, Liano reconstructs in the imaginative space the events that occurred in Patzicía on October 22, 1944, just before the 1944 Guatemalan October Revolution. ${ }^{30}$

${ }^{29}$ See page 19 of the previous chapter

${ }^{30}$ The Revolution of 1944 was a civilian-military movement that took place in Guatemala on October 1944, led by the military, students and workers, which overthrew the military government of General Federico Ponce Valdes. The political upheaval led to the first free elections in the country, and inaugurated a period of ten years in which the State made significant efforts to benefit the working class. The subsequent historiography has referred to this period as the "Golden Age" of Guatemala. The 
Many Guatemalans' know very little about the events that took place in Patzicía. The October Revolution overshadowed the cruelty and violence of the indigenous population lived in the Chimaltenango's municipality. What started as a protest against abuse and racism exploded into a violent confrontation between "Ladinos"-mixed race — and indigenous people of Chimaltenango. The result was 14 "Ladinos" and an unclear number of dead indigenous. The lack of documented records makes it impossible to know the actual number of dead. Isabel Rodas and Edgar Esquit state that:

Estos hechos son poco conocidos para una gran parte de guatemaltecos, pues la euforia revolucionaria nacional de ese año opacó un acontecimiento local, cruel y violento (Las masacres ocurridas entre

constant disrespect for the Constitution by the authoritarian government of General Jorge Ubico Castañeda (1931-1944) was a key factor in the events that occurred in October of 1944. His government, which was completed in 1937, was extended in 1935 for a second term, and in 1941 to one third. His regime was characterized by lack of civil liberties, as well as restrictions on freedom of expression. Despite several positive socio-economic projects of his administration, its policies in favor of the interests of U.S. companies and the Vagrancy Act (under which the peasants had to work for free for 150 days per year in the estates of large landowners), aroused popular discontent, and Castañeda was finally forced to resign July 1, 1944. Castañeda left in power a military junta formed by Generals Eduardo Villagran Ariza, Federico Ponce Valdes and Pineda Buenaventura. Shortly after the board decided to leave the power, General Federico Ponce Valdes, whom the National Assembly appointed interim president.

The opponents of the dictatorship accepted it as a provisional form of government before the scheduled presidential elections to be held by the end of the year. However, Ponce Valdes government widened the political persecution and intimidation. Although Ponce Valdes did not dare to launch a candidacy for the presidency, he did his best to hinder the normal development of political life. Repression increased after seeing the massive reception given to Juan Jose Arevalo on his return from exile, as his candidacy had found acceptance among the population. Ponce Valdes chased and arrested a number of supporters of Arevalo. Soon it was evident that Ponce Valdes had no intention to call elections and tried to prolong his illegitimate regime. Wages fell and repression increased. See Carlos Sabino Guatemala, la historia silenciada, Volume I. 
ladinos e indígenas, el 22 de octubre de 1944), por la tenencia de la tierra y monopolio de pan y carne. . .

Los medios de comunicación de esos años hicieron eco del hecho, pero en términos parciales y alterados, explicando la violencia allí registrada como consecuencia de la tensión política generada por el enfrentamiento entre partidarios del Poncismo y quienes entonces apoyaban al movimiento revolucionario, identificando a los primeros con los indígenas, y a los segundos con los ladinos.” (28)

The historical events above mentioned serve as the motivation for Liano's novel El misterio de San Andrés (1996), evidencing the writer's submersion into the obscure areas of the historical past in order to create a concrete representation of his country's past and present-day reality. The novel can be categorized as what critics have called "The New Latin American Historical Novel." The main characters of the novel are Benito Xocop, an indigenous who acts as the leader of his people-MayaCakchiqueles_-; and Roberto Consenza, a "Ladino"—-mixed race-journalist friend of Benito.

The plot of the novel is deployed by the way in which municipal officials of the village of Sand Andrés Benito deceive the Indigenous by telling them that the Revolution of 44 will bring with it the expropriation of their land. Misinforming them, the municipal officials convince the indigenous to secure their land certificate in the archived of the town hall building. All of these efforts are part of a plan to rob the indigenous of their land. The municipal building is set on fair in an attempt to destroy any evidence of landownership by the group of indigenous in the locality. Angry by 
being deceived, the indigenous group begins a revolt in which many die. Roberto writes a newspaper article reporting the events, but no one pays any attention to his writing. Benito is apprehended and accused of leading the revolt. After serving a long sentence, he returns to his town only to die as an old man under the cold shadow of a pine tree.

The novel recreates one of the darkest episodes in Guatemala's history. Ubico Castañeda's dictatorship and its fall in 1944 which was a dictatorship that was characterized by the abuses suffered by the indigenous through the expropriation of their lands, discrimination, massacre, and racism. Castañeda's government was characterized by an overall culture of violence and intolerance against the indigenous people. This confirms how Dante Liano, like Sergio Ramirez and other contemporary Central American writers, share an obsession for writing and/or rewriting historical events in their literary projects in order to fusion together the extra-literary reality and the fictional representation in their work. By doing so, these writers denounce social injustice in an attempt to bring about social changes. As I shall discuss in the following sections, in a more in depth analysis of El hombre de Montserrat—Liano's second novel—the Guatemalan born writer makes use of the noir sensibility and blends it with postmodern writing technics in order to once more recreate another dark period in Guatemala's history. With this novel, Dante Liano denounces the abuses of the military force during the 1970s and 1980s

\section{3. Dante Liano's Literary Postmodernity}

I will concentrate my discussion of Dante Liano's work to highlight his postmodernity as presented in his novel El hombre de Montserrat in the following 
sections. I will focus my argument on specific conditions of its production. My intention is to demonstrate how Liano reconstructs in the literary space the violence lived in Guatemala in the 1970s and 1980s. To do so, he makes use of the new literary paradigm which foregrounds the individual desires, passions and struggle for survival in contemporary times. I suggest that by incorporating the new standards of fiction writing Liano establishes a model that points towards the thorough skepticism and the lack of any definitive sense of coherent certainty, and that by doing so he produces postmodern fiction. My argument will be focused on some of the formal techniques and properties that Liano incorporate in El hombre de Montserrat and I will analyze how they parallel the techniques of postmodernist formal literature. However, before I begin my study of Dante Liano's novel, I must summarize the plot of the novel.

\section{III.3.1. El hombre de Montserrat: An Overview}

El hombre de Montserrat is a novel that belongs to the new category of noir narrative being produced in Central America. From the very first page of the novel, the reader is introduced to a criminal action and the element of suspense that will remain throughout the novel. The finding of a dead man on the edge of a road near the shopping district Montserrat by army Lieutenant Carlos García - the main character of the novel—one morning on his way to work deploys the plot of the novel. The act of finding a dead body in a city road in the Guatemala of the 1980s is not an unusual event. García has no intentions of investigating the identity of the dead man or who committed the murder at first, but the familiarity of the face of the corpse and a series of unexpected 
events leads him to become intrigued in the matter, and he becomes the detective of the novel.

Lieutenant Carlos García is an army officer trained in intelligence operations and is part of an army logistic team lead by Argentines, Chileans and Americans. Their mission is to track down the location of centers of operation of the guerrillas in the capital city of Guatemala. García, through the years has become a sort of army bureaucrat who spends his days analyzing the electricity consumption of households throughout the city in an attempt to find unusual consumption of energy that would indicate illegal guerrilla operations. García, as a daily and as strictly personal matter, uses his high military rank and the privileges that come with it to check if any of his relatives has been included in the lists of the death squads. García finds out that there is a mystery involving the dead man he found near the Montserrat shopping district through these means. He also learns how some of his wife's relatives are involved in the mystery surrounding the dead man. The plot of the novel moves from depicting the violence in the capital city to describing the violence and the horrors of the war being fought in the Central American nation. The actions narrated in the novel are told through the eyes of García — through the eyes of a soldier.

The reader witnesses many of the military operations against the guerrillas, for example, how the military attacks shelters of guerrillas operations and how they are broadcast live on television programs sponsored by large multinational corporations. The reader also witnesses the constant power struggle between the police force and the army. He or she is capable of noting the corruption that takes place within the offices of the military. In addition, the reader learns about the massacres of Indians who are 
accused, without any proof, of collaborating with guerrillas. These are the social circumstances that loom in the background of the novel as Lieutenant García continues his investigation of the dead man in Montserrat.

III.3.2. Technical Practices in the (Re)construction of Reality in the Narrative Space in Liano's novel

Dante Liano, like Sergio Ramirez, blurs the binderies between fact and fiction within his narrative and by doing so he contributes towards creating skepticism and lack of coherent certainty of reality. The violence of criminal actions and abusive nature of the military forces of the Guatemala of the 1980s serve as evidences in El hombre de Montserrat to the prevalent distrust for the official discourse presented in the historical registers. Even though in Liano's novel the reader never comes across an explicit reference that states that the actions depicted in the novel take place in the Guatemala of the 1980s, series of historical and geographical references that appear throughout the novel make it easy to determine that this dark epoch of the Central American nation serves as the backdrop of the actions depicted in the novel.

According to Ihab Hassan, one of the elements of postmodernity is "indeterminacy," the postmodernist artist's will to unmake. This desire to deconstruct is characterized by the artists' will to undo through the use of ambiguity, discontinuity, heterodoxy, pluralism, randomness, revolt, perversion and deformation in their artistic productions (1987 172). While in Sergio Ramirez's novel—-that I studied in the previous chapter-I analyzed how the Nicaraguan writer makes use of "indeterminacy" as a writing technique in order to create fictional characters who appear to be versions of 
individuals who were involved in the political arm struggles of the Nicaraguan

Revolution, in this section I will attempt to explore how Dante Liano uses "indeterminacy" in order reconstruct in the fictional space the height of the institutionalized violence established in Guatemala by various governments and carried out by the National Army. As a result of using this narrative technique, Liano, embarks in the process of reconstructing the collective memory of the experiences lived by the Guatemalan people during those years and presents a strong social criticism against the violence and the abuse of power of the governing institutions.

Dante Liano in his novel uses the narrative techniques of camouflage and ambiguity as aspects of "indeterminacy" in order to recreate the historical factual world in the fictional one and by doing so he exhibits the postmodern concern for historiography. The use of these narrative techniques serves the author as a vehicle to construct a new perspective of historical accounts and question the official discourse. Taking into account that in Liano's novel the country and the historical period of the novel is tacitly mentioned, the actual time period in Guatemala's history can be determined by the following lines from Guatemala: Memoria del silencio, a summary report written by the "Comisión para el Esclarecimiento Histórico" (CEH). ${ }^{31}$

Durante la década de los 60, además de los enfrentamientos entre la guerrilla y el Ejército, la violencia por parte del Estado se dirigió contra la población campesina en el oriente del país. En la década de los 70, tuvo

${ }^{31}$ The Historical Clarification Commission was established by the Oslo Agreement of June 23, 1994, to clarify with objectivity, equity and impartiality the human rights violations and acts of violence that caused suffering among the Guatemalan people, linked with the armed confrontation of the 1960s, 1970s and 1980s. 
especial virulencia en la ciudad y se dirigió contra líderes de movimientos sociales y sectores de oposición a los sucesivos gobiernos militares, además de contra la infraestructura guerrillera. En los primeros años 80 la política contrainsurgente se convirtió en terrorismo de Estado, conllevando un proceso de destrucción masiva especialmente de las comunidades indígenas y grupos campesinos organizados, que superó todas las previsiones del horror y frustró todas las esperanzas de cambio (3).

Fear, terror and repression characterized this dark historical period in Guatemala's history and through the use of camouflage and ambiguity Dante Liano reconstructs it in his novel as a way to reinterpret the past and denounce the military abuse lived in those years.

One specific event, in El hombre de Montserrat, that alludes to the violent historical period of repression in the Central American nation is the reinterpretation of the events that occurred in 1981 in the Guatemalan capital. In the neighborhood of Vista Hermosa, Guatemala City, the National Army discovered a house where the guerrillas carried out clandestine operations against the government. One morning the military opened fire and bombed it. The house was destroyed and everyone in it was killed. In the novel, these events are camouflaged and transferred to the work of fiction in the following manner:

!Bajá la velocidad, vos mierda!—ordenó García, previendo la cuesta de Vista Hermosa-. Sólo eso nos faltaba que nos hicieran un par de bajas antes de comenzar... Dos heliconpteros volaban en círculo, a la 
izquierda, sobre la Universidad del Valle. García vio su reloj. Las diez de la mañana. Hora de clase. A ver si no había massacre de estudiantes. . . . [The house] [e]ra un pequeño edificio de dos pisos.... En algunos lados se abrieron hoyos que borraron la impresión de fuerza que daba la casa. García vio, a través de los binóculos, dos soldados que se arrastraban hacia ella, cubiertos con un incesante fuego de protección. De la ventana rota, partieron dos granadas, que cayeron en medio de los dos. Un luzazo y como monigotes, los cuerpos se levantaron un momento y fueron a caer despatarrados por los costados.... Los golpes de mortero habían derrumbado casi por complete la pared de protección. El jardín había agarrado fuego con ferocidad y el humo blancuzco de las plantas se confundía con el humo negro que venía del interior de la casa.... Dispararon tres morterazos. El estallido venía por el viento. Los morteros cayeron sobre su blanco como grandes piedras sobre una montaña de papel. Las llamaradas eran feroces. Se oían lejanos alaridos.... Parecía imposible que antes hubiera habido una casa en donde ahora se alzaban los escombros,ennegrecidos. (57-66)

Another instance in the novel in which the violent years of the early 1980s are alluded in the novel is made evident by the reference to the Falklands War of 1982 between Argentina and the United Kingdom. García works as part of a military counterinsurgency team along with several international military advisors. There were several Argentineans among them. When García was reinstated to his old job, after having been sent to fight in the jungle for a short period of time as a form of punishment 
for helping his brother in-law escape facing being questioned by the military for his involvement in anti-government actions, he finds that the Argentineans have gone back to their country:

Su castigo en la selva había terminado gracias a las elecciones. El general Vargas, caído en desgracia, fue enviado como embajador a París. Algunos oficiales jóvenes fueron llados a la capital, y entre ellos estaba García, pues el encargado de seleccionar a los privilegiados era un antiguo compañero de la Academia, amigo del president. De modo que García regresó a su empleo. Ya no encontró a los asesores argentinos, que después de la revolcada que les dieron los ingleses, se habían regresado a su rancho. Ahora los estaba procesando. (146)

I must make the clarification that this historical reference, which appears towards the end of the novel, provides the exact moment of the actions depicted in the novel. In 1982, Guatemalans witness the overthrow of Guatemala's $25^{\text {th }}$ President Fernando Romeo Lucas García. Lucas García was democratically elected in 1978 and his administration has been categorized as one of the most repressed regimes in Latin America and together with the government of El Salvador, the Lucas García regime was cited as the worst human rights violator in the western hemisphere. Whereas under the previous administration the human rights situation in Guatemala had improved, the regime of Lucas García brought the repression to the same level observed during the "State of Siege" under former President Arana Osorio (1970-1974). The election of Lucas García was followed by an increase in the extrajudicial killing, torture and 
disappearance of union leaders, intellectuals, ${ }^{32}$ peasants and religious leaders. The daily number of killings by military forces and officially-sanctioned death squads increased from an average of 20 to 30 in 1979 to a conservative estimate of 30-40 in 1980. Government forces in Guatemala killed an estimated 5,000 civilians in 1980. In 1981, the number of killings and assassinations by government forces exceeded $9,000 .{ }^{33}$ Indeed, this was a government characterized by an overall culture of violence and intolerance against those who opposed and questioned the system of government. As noted in the above-mentioned examples, Dante Liano's novel, El hombre de Montserrat, makes use of the imaginative space as the sphere to (re)create, to reinterpret the violent past of the decade of the 1980 in Guatemala. The novelist makes use of the new noir sensibility in Central American letters and the formal experimental techniques of postmodernism to embark in the process of reconstructing the collective memory of the experiences lived by the Guatemalan people during a decade marked by the violence and the abuse of power of the governing institution in the Central American nation.

\section{III.3.3. The Theme of Violence in El Hombre de Montserrat}

In my analysis, I have established that the new Central American literary project presents a mixture of fictional trends linked to the testimonial account, the historical, the political, the mystery and the thriller literature. The postmodern concern for

${ }^{32}$ Dante Liano himself was a victim of the repressive nature of this government. In a trip to Italy to attend an international literature conference, he decided to stay and escape the repression. He has lived in the European country since 1980.

${ }^{33}$ See Jim Handy Gift of the Devil: A History of Guatemala (1984). 
historiography through the formation of complex relationships between the extra-literary reality and the fictional representation of reality narrative is highlighted in these texts. Most specifically, through the act of re-writing historical events and using postmodern writing techniques, like indeterminacy, the novelists denounce the social inequality and the use of repressive force of the regime to quiet down demands for social change through the incorporation of themes like: racism, discrimination, authoritarianism, expropriation of land, military abuse and death. In El Hombre de Montserrat, Dante Liano forefront the theme of violence as a way to recreate in the narrative space the hardship of the internal political struggles of the Guatemala of the 1980s.

Liano in his novel portrays the power struggle between two opposing political forces, the National Guatemalan Army and the revolutionary force that opposed the governing system. Terror, repression, acts of torture and death—typical factors of war - take center stage in the novel as multiple aspects of the violence present throughout the novel. The list of war elements listed above (terror, repression, torture and death) is also present in any form of noir narrative. Let's remember that the environment in which the plot of a good noir novel takes place must present an atmosphere of violence, terror and death. In El hombre de Montserrat all the elements of a well-developed noir novel are present, for it not only contains the intrigue of an investigation brought about by a criminal action, but also foregrounds a social criticism to a specific socio-political system in which oppression, violence and death are everyday occurrences.

The first sign of violence in El hombre de Montserrat, is presented in the initial description given by the narrator of the dead man near the Montserrat Shopping Center: 
Alguien le había descargado la tolva, al infeliz, con pésima puntería y una gran suerte. Sólo uno de los tiros parecía mortal, el de la cabeza. De seguro se habían pegado y luego el asesino comenzó a disparar. O, tal vez, el primer tiro fue el mortal y después, de la pura cólera, le descargó la pistola. (16)

In this description the reader is able to note the brutal way in which the victim suffered the violence of his attacker. The plot of the novel develops in a linear process of events in which the violence of war is an everyday occurrence. The natural state of gloom, agitation and fear associated with the sense of living in an environment where violence is constantly present seems to have little effect in the lives of the characters of the novel. The constant presences of threatening acts have become an ordinary event for them, and they have learned to carry their everyday activities without putting too much thought on the matter. The following paragraphs from the novel, exemplify how the violent effects of the civil war of the 1980s have very little resonance in the home life of a Guatemalan like Lieutenant García and his wife:

Se sentó en el sillón de la sala. Sintió que el plástico que protegía los cojines se le pegaba en la espalda.

-Oí en la radio que hubo un atentado—-dijo su mujer-. Menos mal que no fue en tu cuartel.

-¿Ah sí? -observó García-. ¿Y dónde dijeron que fue?

-En la guardia Nacional, dijeron. . ¿querés café? (25)

... A lo lejos, en la ciudad, una sirena se fue desenrollando.

“QQuién será el desgraciado?”, pensó [García]. Casi en seguida, oyó el 
desgranarse de unas ametralladoras. Otros respondían al fuego. Oyó un retumbo y reconoció el sonido de una granada de mano. Después otra. Luego, el fuego cruzado de las ametralladoras. Dos, tres bombazos. Inmediatamente, el silencio. Pocos tiros aislados. "Se acabó la escaramuza", pensó (44).

... En el semáforo del Parque Morazán comenzaba la cola de carros. Dos voceadores vendían los periódicos. Le hizo de señas a uno. El hombre pegó una carrerita, con el bulto de periódicos bajo el brazo. -¿Prensa, Gráfico?-le preguntó.

-Dame la Prensa -le dijo... Mientras comenzaba a avanzar, [García] le echó una ojeada al título [of a news paper article]: ATAQUE SUBVERSIVO EN SOLOLÁ. Debajo había fotos de los cadáveres, como siempre. Ya no podía acordarse como eran los periódicos antes de la guerra. (48)

The constant confrontations between the Guatemalan National Army and the revolutionary forces and their negative consequences were everyday events during the years of the Guatemalan civil war of the 1980s and, as seen in the three paragraphs above, people learned to continue their lives without any sign of alterations. Furthermore, the terrors of these confrontations were not limited only to the urban space. Liano makes an extraordinary job at transferring the miseries of the consequences of the military hostilities lived in the interior of Guatemala to the pages of his novel. Among the most terrifying consequences of the armed struggle conducted in the jungles of Guatemala — and that are made present in the novel — are the massacres of indigenous 
people; who in many instances, were falsely accused by the military force of aiding the guerrillas as seen in the following paragraphs of the novel:

En efecto.

Esa mañana cayeron sobre una aldeíta que estaba cerca del río. De la base les habían informado que se sospechaba que había colaboradores o inclusive guerrilleros entre ellos. Sólo se podía alcanzar con helicópteros o a pie, entre la selva, a través de un camino conocido por el baquiano que les abría el paso. "Igual a todas”, pensó García cuando vio el humo de casas en el claro de la vegetación.

Los indios se habían encerrado en los ranchos. Los sacaron a todos a la plaza. Tenían los ojos vidriosos del temor. Los soldados les gritaban, los empujaban, los pateaban. Ellos obedecían con las quijadas temblerequeantes, con el rostro terroso, con las canillas que les flaqueaban. No parecían animales, porque el animal acorralado se defiende, muestra los dientes, saca las garras. La gente, en cambio, se vuelve toda ojos, toda súplica, un puro nudo de angustia y asqueroso terror.

García apenas daba órdenes. El ritual era el mismo y los soldados ya estaban habituados. Gestos. Chasquidos. Guiños. El sargento llamó a cinco de una lista que les habían preparado en la base.

No hubo modo de saber nada. Los nombres de la lista correspondían a gente denunciada por infiltrados o por informadores o por 
simples denunciantes. El sargento les gritaba, preguntándoles si estaban metidos en la mierda.

-¡Aquí están, mire!—insistía—. ¡Aquí está tu nombre, ve! En la mierda están ustedes y mejor si me lo van diciendo chanín, y quién del pueblo los ayuda, pero ve: rápido, que me estoy cansando! (128-129) The violent nature of the military force against the indigenous in the novel reached its peak in the brutality in which several of the Indian villagers are murdered as depicted in the next scene in the novel:

Parecían idiotas. Decían que no, pero tal era el miedo que no convencían a nadie. Los amarraron. Los rociaron de gasolina. Les prendieron fuego. La gente del pueblo se estremeció como con un temblor, mientras los cinco de la lista caían al suelo, gritando y achicharrándose.

-¡Ora me lo dicen! - gritó el sargento—. ¡YYa vieron lo que le pasa a los subversivos! Ora me dicen quién está metido en la mierda, si no, nos los soplamos a todos. . .

Ya la gente comenzaba a suplicar, y esto desagradaba a García. Se dirigió al grupo:

-No, señores, Con rogar no se gana nada. Aquí o hablan o se mueren. Gente hay de sobra en el mundo y de la mierda no debe quedar pero ni la semilla, ¿me oyeron? ¡Ni la semilla!

Los kaibiles se enfurecían al ver la sangre. La gente gritaba y eso a ellos más bravos los ponía. Separaron hombre de mujeres. A unos los metieron en una casita, que servía de escuela y juzgado. A las otras, en 
una iglesia protestante. Luego, los mataron a todos. Con arma blanca, para no desperdiciar plomo. Había un detalle que siempre le llamaba la atención al teniente García: la cantidad de sangre que contiene un cuerpo. Litros y litros. Al final, en la escuelita, se había formado una poza. (129130)

Dante Liano in his novel invariably mixes elements of fact and fiction within his narrative. He recreates a complete panoramic view of the entire violent epoch of the Guatemala of President Fernando Romeo Lucas García, one of the most violent governments in the American region. These violent years serve as the setting for the fictional detective process behind the killing of an unknown man found near Montserrat Shopping Center. The novelist contributes towards creating a sense of scepticism and of lack coherent certainty of reality as presented by official discourses of historical accounts by combining fact and fiction in his literary production. Liano's writing techniques exemplify aspects of postmodern writing. The constant presence of the terror and the violence perpetuated by an abusive military force in Dante Liano's novel serves as a continuous reminder of the horrors lived under Lucas Garcia dictatorship.

III.3.4. El Hombre de Montserrat as a Postmodern Parody of the Detective Narrative I suggested in chapter one of this dissertation that the literature produced in the United States during the $20^{\text {th }}$ century had great influence in the Latin-American literature particularly in writers of the Post-Boom generation. ${ }^{34}$ Since the 1960s, the literature

\footnotetext{
${ }^{34}$ See section I.5.
} 
produced in Latin-American countries has a strong tendency to establish intertextual links with U.S. literature, especially in the way social themes are presented by the use of new and experimental techniques. At first glance, the reader can assume that $E l$ hombre de Montserrat, is a typical noir detective novel inspired by the American tradition, full of those formulaic elements that made the genre one of the most prolific narratives around the world. The external structure of the novel consists of five chapters mark by Roman numerals - which are subdivided by short sections - and an epilogue. The internal structure of Liano's novel, following the classical detective novel, consists of the introduction of the crime - the finding of the dead body (chapter I, sections 1-2); the investigation of the crime (chapter I - V); the solution of the crime (epilogue). In the novel, the epilogue is of great importance to the entire novel. The epilogue states the solution of the crime and suggests Lieutenant García's future. The suspense and the mystery surrounding the death of the "Man of Montserrat" - the true identity of the murderer, as well as the motives for the crime - are clarified in this last section of the novel. One important aspect that we note throughout the novel that links Liano's novel to the noir detective genre is the fusion of the narration of the crime and the investigation within an environment full of violence. In doing so, Dante Liano in $E l$ hombre de Montserrat exhibits what Todorov has determined as an essential aspect of the noir narrative when he states that: "La novela policial de la serie negra funde ambas historias en una sola, subordinando el element del misterio (la curiosidad o búsqueda de respuestas) al suspense (expectación) proporcionado por la acción, en un clima de violencia desatada" (Colmeiro 44). Thus, one can assume that El hombre de Montserrat is a typical noir novel that is very much inspired by the American tradition. However, 
the careful reader will immediately note that in his novel Liano takes the main features of the noir detective novel and shape them into a postmodern parody of the genre.

Mikhail Bakhtin argued that parody is a stage in the natural development in the life cycle of any genre. Thus, a genre will eventually reach a stage where it begins to be parodied. Parody in the postmodern cultural production has become one of its particularities. In his book The Postmodern Condition: A Report on Knowledge (1979), Jean-Francois Lyotard argued that society has lost faith in the "meta-narratives," Grand belief systems like religion, political ideology, and even cultural forms like architectural style or cinematic genre. Hence, postmodern culture always parodies the conventions of earlier forms.

Liano's novel—like the noir narrative of Hammett—depicts the sociopolitical circumstances under which it emerged. Let's remember that Hammett was among the pioneers who used the detective genre to create a mimesis of the real world. Liano in his novel makes use of the investigative process to recreate an entire epoch full of violence and death in Guatemala. In his novel, Liano-like Ramirez, Castellanos Moya and Fonseca Mora—revitalizes the detective genre through the use of effective postmodernist technical resources such as the parody and re-invent a genre of narrative that when first conceived because of its ideological and political conservatism could never have been imagined capable of portraying the violence of the war affected Central American region.

Dante Liano and the other three Central American writers studied in this dissertation are skilled writes who in their new versions of the noir novels create atmospheres full of suspense and emotions necessary to engage the interest of the reader. 
Liano with his new version of the noir novel has proven to have the ability to regenerate the genre. He is among a long list of Latin American writes who in the words of José Colmeiro have "[1] as habilidades para crear nueva vitalidad a los estereotipos y la capacidad de crear nuevos toques de trama o marco que estén todavía dentro de los límites formulaicos" (51). Liano in El hombre de Montserrat, through the combination of postmodern narrative technics — such as the parody — and a well-structured plot that incorporates several of the features of the formulaic noir novel-like a plot full of intrigue - is able to recreate a historical moment when crimes committed by the military forces in Guatemala during the decades of the 1970s and 1980s where everyday occurrences.

As stated before in El hombre de Montserrat, there is a crime, a victim a perpetrator and even a false criminal. Most importantly, the narrative does not forefront the description of the murder that deploys the investigation. Instead, it is the efforts to discover the perpetrator of the assault that serves as the pretext for the author to transfer a historical reality to the literary representation of reality. In my analysis of Liano's novel, I find that the main parody element in the novel lies in the author's construction of a clumsy and banal detective who is incapable of using the evidence he finds to solve the riddle of the crime. Unlike the classic sleuth who has a deep understanding of the mechanisms that govern the world and the human psychology, Lieutenant García - the protagonist in Liano's novel-is an antihero figure that lacks the credibility, strength and intellectual clarity, which are essential characteristics of a sleuth. The reader is presented with a caricature of the detective. From the very first pages of the novelalong side with the intrigue and suspense that prevails throughout the novel - the 
mockery that the author makes of the figure of the detective is easily recognized. One morning on his way to work, Lieutenant García spots a body on a road near Montserrat Shopping Center. He immediately realizes that is a corps and driven by the curiosity of seeing if the dead man might be someone familiar and not because he wants to do his duty as a member of the police force and investigate the magnitude of the crime. Very unprofessionally he manipulates the body and sorry to have found out that indeed it was a dead man García begins to regret having stop to satisfy his curiosity. His actions are very incongruent with the typical duties associated with the role of a law enforcement agent:

No le falló la intuición. El muñeco grande que parecía caído de un cartelón publicitario estaba bien muerto, probablemente de hacía poco, pues todavía lo sintió aguado cuando trató de moverlo.

Con la punta del pie lo sacudió un poco, diciéndole: -usted, usted. .

Hasta que reparó en la pocita de sangre que se había formado. Se rascó la cabeza, pues quién le mandaba haberse parado. Ahora tenía que sacudirse lo más pronto possible de la molestia.

Volteó el cadaver, por curiosidad. Pesaba como un quintal. Era un tipo bigotudo y fuerte, más negro que volverlo a decir y con cara de pocas pulgas. "Éste ha de haber sido de mal caracter", pensó. (15)

García's character lacks any special features that would place him among the great heroes of the classical detective genre. He lives a very monotonous life. He wakes up; goes to work and perform a very mechanical job; returns home to a very traditional 
home where his wife waits for him and is ready to please all his desires; and through this banal existence all he can think of is how to make a better life for him and his family without much effort. García's character also exhibits the brutality associated with the military leaders of the epoch in Guatemala. Through this character, Dante Liano presents a strong criticism against the police force and the governing system he represents. In the novel, Lieutenant García is described as followed:

Carlos García era un militar, y, lo que es más importante, lo parecía. Era alto y bien plantado, con treinta y cinco años bien vividos en los cuarteles, lo que a la reciedumbre natural añadía un vigor proveniente de marchas forzadas, castigos, pateadas, plantones y, sobre todo, las buenas comidas que en su casa se las hubiera soñado. Moreno cobrizo, con el pelo negro lacio encepillado y muy corto, se parecía al Tecún Umán del parque, si no fuera por lo cachetón y por la panza que las abundantes cervezas le habían regalado. Aun vestido de civil, como ahora, por los modales bruscos y el vozarrón del que está acostumbrado mucho a mandar y poco a obedecer, no podía ser más que un militar. (16-17)

Through García's physical description and the aspects of his personality that the novelist provides, one can recognize how Liano makes an emphasis on stressing the violent nature of the typology of the soldier, very much recognizable for the coarse behavior in which the military conducted their daily business during the 1970s and 1980s in Guatemala as I have noted in the previous section of the analysis of Liano's novel. Adina Pascalau states that García's character: 
Lejos de tener el genio para desenredar los hilos complicados de un crimen, el teniente se acerca más a un ser robótico, ya que no sólo está desprovisto de las finuras analíticas, sino que también parece carecer de cualquier cualidad que identifica a un hombre moral. Su existencia dentro del entorno de la amoralidad se nos hace evidente con la descripción de las reacciones que tiene en el momento que encuentra confrontados al ejército y los guerrilleros sitiados, cuando, además de unirse al sadismo de la intervención militar, trata con desprecio el impacto emocional que la violencia desproporcionada tiene sobre los periodistas: “—¡Pa'qué se meten a cosas de hombres! —le gritó García. . ¡Más machito, hombre, más machito!- - le dijo mientras lo abandonaba a su futuro de insomnios y pesadillas." (El hombre de Montserrat. Barcelona: Roca Editorial, 2005,

61) Su actitud demuestra la justificación de un comportamiento inhumano y, para el autor, sirve como denuncia de todo el conjunto militar que representa. (13)

Lieutenant García's character in the novel exhibits many of the main characteristics of the protagonist of the noir narrative. He is described as a man of flesh and blood, as common as any other ordinary man. He is far from being the critical thinking machine of exceptional brilliance. He is not a professional detective, above all he is a military trained officer, who in the novel he indirectly finds himself portraying the role because of unusual circumstances. Liano in the novel emphasizes Liutenant Garcías militaristic personality as seen in the following quote: "Al llegar al parque Montúfar, compró el periódico. Le echó un vistazo en lo que el semáforo daba verde. García sintió 
una pequeña satisfacción cuando metió primera y entró en la calle Macedo, "Ahora sí le dimos verga", pensó, contento de pertenecer al ejército" (97) .

In reading the headlines in the newspaper, García finds-out how the military was able to defeat by brutally killing a small group of the guerrilla that operated in the city. He is proud of being part of a system that is erradicating the menaces of social changes that are believed to have close links with the Communist ideology. Most importantly, his sence of pride grows strong because he feels that his work in the military intelligence team to detect the revel cells in the city of Guatemala is proving to be effective. In the novel, this is one of the few instances in which the reader can note an emotion not affiliated with the anguish, despair and hopelessnes that charecterize the violent environment in which the novel is set and that is typical of the noir narrative. Another interesting characterisitic of Liutenant García's character as a parody of the figure of the seluth in the detective litarary tradition and that also exhibits one of the personality traits associated with postmodernity is the emptiness associated with a banal exhistance. García's everyday reality is very predictible. He wakes up, goes to work to perform a very mechanical job and comes home to a pleasing wife. Lieutenant García lacks any motivation to improve his dull existence. Even though in the novel it is noted that he has desires for a better home and a better car, he does not do much to attain them. At the end of the novel, the reader notes that even after living the experiences depicted throughout the novel, Luitenant García retains the same sentiment of hoplessnes and emptiness that only a state of constant violence can provide: “Así que cayó en el vaivén de antes. Se levantaba temprano, ponía a calentar el motor del carro mientras desayunaba, se iba al trabajo, regresaba, se dormía, sobrevivía" (146). Furthermore, 
another passage from the novel that helps illustrate the sense of desolation in which García has lived his life during the hardship of war appears at the end of the novel when the truth of the enigma of who killed the man at Montserrat Shopping Center comes clear to him: "Cuando se montó en el carro, el teniente Carlos García se puso sentimental. Confirmó que había fracasado en la vida. La radio transmitía boleros y durante el camino hacia su casa, no pudo quitarse de encima ese pensamiento. Todo lo que había hecho estaba equivocado. Y la equivocación le iba durar toda la vida" (148-49).

All in all, García represents the antihero figure inspired by the noir narrative that is full of vices, who is hopless and speaks and acts according to the violent environment that he inhibits. Liano's construction of a clumsy and banal detective whose failure through the novel to connect clues that would lead him to find out who was behind the death of the man of Montserrat and the motives of the crime during his investigation, demonstrates how this character is a parody of the sleuth of the noir tradition. Lieutenant García, far from being capable of having the wit to resolve the mystery that deploys the plot of the novel, represents the barbaric military system which inefficiency and opportunism characterized the criminal actions and abusive nature of the military forces of the Guatemala of the 1970s and 1980s. Dante Liano employs the postmodern feature of parody in the narration of a detection to recreate in his novel one of the most violent moment, characterized by military brutality and social injustice, in the history of the Central American nation. 


\section{III.3.5. Other Characters in El Hombre de Montserrat}

The sense of misery brought about the constant state of violence that prevails through the novel can be noted in the coarse actions - typical of a high rank officer of the military — of Lieutenant García or in his lack of personal ambitions. The bleakness instilled in the novel by the brutality of the current state of affairs can also be seen in the actions of other characters in the novel. As I have noted, Liano's protagonist is part of military machinery that specializes in instilling terror in those individuals who speak or demonstrate opposition against the ruling party, like "Tono," who falls victim to the terror of the military death squads.

"Tono" in the novel represent the group of young individuals who through clandestine actions fight against the social injustice that characterizes the ruling government. The political ideology of "Tono" can be noted in the following conversation that occurred between García and "Tono" when García decides to help his brother in law escape the wrath of the military death squads.

-¿Y cómo se metió en esto? — preguntó García, a quemarropa.

-¿Cómo por qué? ¿No ve cómo está el país?

-Hecho mierda, a causa de ustedes.

-No, Chalie. La gente se viene muriendo de hambre desde antes que existiera la guerrilla.

-Ahora se muere de hambre y a balazos. Mire la gracia...

-Mejor morirse con una bala atravesada que de alboroto de lombrices, como los coches.

-Lo que ustedes quieren es el hueso y se acabó. 
-Sí. El hueso, primero. Pero una vez en el poder, se acaba la miseria, usted. Uno no se echa al monte porque tiene ambición de ser alcalde, o juez, o lo que sea.... Para eso, basta sacar el título y saber venderse. Lo que pasa con ustedes los militares es que no saben lo que es un ideal. Por eso van a perder la guerra. (114-15)

Through "Tono's" political ideology, it is easy to note the political discourse of the guerrilla movement that wanted to put an end to the terror instilled by President Fernando Romeo Lucas García in Guatemala. This is a revolutionary discourse very much similar to the one that inspired the actions of the revolutionary heroes turned detectives in Ramirez's novel studied in the previous chapter. One last point to note about "Tono's" character is that through the novel he is believed to be the killer of "The Man of Montserrat." The incorporation of false leads and of a suspect who in the end proves his innocence in the criminal action that deploys the detection in the novel demonstrates Dante Liano's high skills to produce what I have determined as the new postmodern noir novel in Central America.

A good detective story would not be complete without a good enigma. In $E l$ hombre de Montserrat, one enigma was not enough to catch the reader's attention and maintain the suspense through the novel. The novelist presents two puzzles behind the criminal action that occurred one morning near the Montserrat Shopping Center. The reader finds out who committed the murder of "The Man of Montserrat" and the true identity of the victim only toward the end of the novel. The true identity of the victim is Marcos Barnoya. 
Barnoya is a shady character whose actions through the novel seem to indicate that he had close ties with illicit endeavours. Through his actions, another aspect of the state of gloom brought by the violent environment that surrounds the novel can be noted. A few years before he was found dead near Montserrat Shopping Center, Barnoya had befriended Ramón Gomez, García's brother in law who died in a car accident two years before the actions narrated in the novel. Barnoya according to "Tono" took part in the death of Ramón and of usurping his identity in order to carryout fraudulent actions in several business transactions. "Tono" narrates to García in the following fragment from the novel how one day a clerk from the courts office visits his house with a subpoena for Ramón to appear in front of a judge and face the accusations of fraud against him brought to the court.

El licenciado se asustó mucho, porque él ya había hablado con los estafadores, uno de los cuales se hacía llamar, presentaba documentos y firmaba como mi hermano. Se imagina usted cuál no sería mi indignación. Afortunadamente, el abogado había sacado, de escondidas, copias de los documentos de los tipos, en cuanta las fotos. Así que me enseñó la foto del impostor. Y allí mi segunda sorpresa. Reconocí, en la foto, a uno de los amigos íntimos de aquél, un tal Marcos Barnoya, con el que parrandeaba en los últimos tiempos. A mí nunca me había gustado porque era mero lambiscón. Pero nunca pasó de allí. En cambio, ahora que lo vi suplantando a mi hermano, me puse como la gran flauta y le pedí al abogado que nos pusiéramos de acuerdo para clavar al cliente ése. (31) 
Barnoya's involvement in the accident that killed Ramón can be noted in the following comment from the omniscient narrator of the novel:

... El amigo contó después, a los familiares, que se retrasó unos minutos porque, borracho como estaba, creyó que había pinchado una llanta. Se bajó, comprobó que todo estaba en orden y enfiló por la carretera Kennedy. A la altura de los moteles que están delante de Villas del Pilar, vio que había ocurrido un accidente. Se paró. Al lado de la carretera, había un Rambler desportillado y humeante. Su conductor Ramón Gómez, el alegre cuñado del teniente García, estaba muerto. El amigo era Marcos Barnoya. (34)

We can also note "Tono" and of Martín (a friend of Ramon) 's suspicions of Barnoya involvement in Ramón's death:

-Pues fijáte vos que cuando murió Ramón-siguió Martín—- todos los amigos nos quedamos de una pieza al saber el único testigo del accidente había sido el tal Marcos Barnoya. Porque el problema es que Marcos no se quedó allí. Vio el carro destrozado, reconoció a tu hermano y se largó. Luego dijo que había sido porque estaba borracho, y, en el pánico, se fue.

"Yo no sabía ese detalle. Siempre había creído que Marcos se había quedado acompañado al cadáver. “-Pues no. Fijáte vos que no-insistió Martín-. Y decíme vos, ¿qué hace un amigo en un caso de ésos?

“-Se queda_-Le respondí.

“-En cambio, ese cabrón se fue huyendo. 
"Había un fuerte rencor en las palabras de Martín. Percibí un brillo de ira y resentimiento en sus ojos verdes, un gesto amargo en las dos líneas de su boca. Más allá del recuerdo, cerca en el tiempo, vio hacia la ventana que estaba a mis espaldas mientras repetía.

“-Ese cobarde. (36)

The passages from the novel that I cite above not only demonstrate the shady qualities of Marco Barnoya who appears to have fallen victim to his own criminal actions, but also show how "Tono" is the first to take actions and investigate the real motives of his brother's death. As "Tono" gets closer to finding out the truth behind the mystery of his brother's death, he is wrapped in another mystery, the death of Barnoya.

In the previous paragraphs, we have presented the physical and personality traits of several main characters in El hombre de Montserrat. These characters are true representation of the characters of the noir narrative tradition. They exemplify how Dante Liano has mastered the art of writing an engaging novel of detection by incorporating many of the typifying aspect of the contemporary Central American letters and of postmodernist cultural production. By doing so, the Guatemalan born writer helps establish a new literary trend very much shaped by the reality of the isthmus. In this section, I have discussed the role of Lieutenant García as the detective, the role of Barnoya as the victim and the role of "Tono" as a suspect for the killing of "The Man of Montserrat" in my analysis of the characters of Liano's novel. Now, I will discuss who really committed the crime.

Just like in a very good novel of detection, the reader of El hombre de Montserrat does not learn who the perpetrator of the crime is until the end of the novel. Liano proves 
to be an excellent noir novelist, among other things, by confusing the reader with a series of false clues regarding who committed the crime that deploys the plot of his novel. Filiberto Sobalvarro, the husband of García's sister-in-law, is the killer. In the novel, Sobalvarro plays a secondary role and is only mentioned a couple of times. The reader would have never made the connections between the victim and his killer by the limited amount of information provided in the novel about this character. However, when the true identity of the killer is revealed at the end of the novel, Sobalvarro's motivations for killing Barnoya proves to be logical. The first indication presented in the novel regarding Sobalvarro appears almost at the beginning of the development of the plot: -¡Teniente García, teléfono! Los demás protestaron por la interrupción. García rompió el grupo y se acercó al teléfono.

$-¿$ ¿Aló?

¿Chali? -no reconoció al que lo llamaba.

$-\mathrm{Si}$, soy yo. .

-Soy Filiberto, ¿qué tal vos?

-Muy bien, gracias -reconoció a su concuño, que jamás lo llamaba.-Y vos, ¿qué es ese milagro?

-Pues nosotros por ahí pasándola—dijo Filiberto.

"Y éste, ¿qué se traerá?, pensó el Teniente. Durante un segundo, antes de que el otro rehilara la conversación, pudo percibir el ruido que hacían los que estaban tomando café.

-Fijáte que me gustaría platicar de una coas con vos... 
Suspenso, Filiberto hizo una pausa. Luego siguió:

Es algo muy tardado de platicar por teléfono.

¿Qué decís si nos juntamos en un café?

"Ni que fuéramos novios", pensó el Teniente.

-Cómo no, vos, con mucho gusto—-le respondió. . (21)

Lieutenant García from the beginning of his telephone conversation with Sobalvarro recognizes a strange behavior in Sobalvarro's action, and the conversation he has with him at the café proves to García that there is something ambiguous about Sobalvarro's desire to meet with him. Nonetheless, García does not pay much attention to the matter. The reader learns Sobalvarro's true motivations for establishing a meeting with García at the end of the novel. His motives were to find out how much was known about the killing of "The Man of Montserrat" by the authorities. He wanted to know if there was any suspicion about him. Sobalvarro killed Barnoya after finding out that Barnoya had betrayed him in a monetary scam that involved a church organization. I have attempted in this section of my work to exemplify a very important peculiarity of the noir narrative present in Dante Liano's novel El hombre de Montserrat. I have established that as a good representation of the noir narrative tradition Liano's novel stylistically speaking incorporates the direct writing style and the gritty realism of the "hardboiled fiction." As I stated in the first chapter of my work, the term "noir" fiction evokes a sentiment of pounding despair and a portrayal of a fatalistic world. The sense of gloom in Liano's novel is presented in the violence of the war and by the coarse actions of several of the characters in the novel. Thus, I can conclude that the suspense in the novel is brought about by a detailed description of the gory environment and the actions 
of the carried out by the key characters of the novel. Dante Liano in his new interpretation of the noir narrative recreates the atmosphere of violence, terror and death that characterized the war years under President Fernando Romeo Lucas Garcia in Guatemala.

\section{III.4. Horacio Castellanos Moya’s Literary Project}

Castellanos Moya's literary project—like Ramirez's and Dante Liano’s narrative-is a literature that foregrounds the multiple tendencies in the political, historical and esthetic trends in Central American. Castellanos Moya in his writing, transfers the extra-literary reality to the fictional work by placing at center stage themes of social injustice brought about by the political turmoil lived in El Salvador during specific historical periods of the $20^{\text {th }}$ century. Violence and death are leitmotifs at the core of Castellanos Moya’s narrative. Just like Ramirez's and Liano’s writings, Castellanos Moya makes use of experimental techniques like, parody, metatextuality and metafiction to produce a fiction that is much characterized by a fusion of irony, humor and social protest. In an interview for the online magazine Página/12, Castellanos Moya noted that his literary project is well connected to Salvador's recent history: "Aunque no sé muy bien qué es el destino, creo que mi rumbo literario ya está marcado. Aun cuando amplíe mi horizonte geográfico y sitúe alguna de mis novelas en otro sitio, mis personajes serán salvadoreños," said the writer (21, June, 2011).

Horacio Castellanos Moya was born in 1957 in Tegucigalpa, Honduras. He is the son of a Salvadorian father and a Honduran mother. He grew up in San Salvador where he lived and studied literature. He left his country in 1979 to study history in Toronto, 
Canada. He then returned to San Salvador and was active in the political movement of the Fuerzas Populares de Liberación (FPL, Popular Liberation Forces), ${ }^{35}$ but eventually his adhesion to the leftist movement declined.

Castellanos Moya lived for most of the civil war era in Mexico City, where he served as editor, journalist and political analyst. He has worked as a journalist, as a reporter, editor and publisher for several newspapers and magazines in Mexico and El Salvador. His writings have been disseminated by numerous periodicals of Latin America, among them the newspaper La Opinion (Los Angeles, California), the magazines Tendencias y Cultura (San Salvador, El Salvador), the journals The Journal do Pais and Cuadernos del Tercer Mundo (Rio de Janeiro), the newspapers El Día and El

${ }^{35}$ The FPL joined in 1980 other Left-wing revolutionary movements and became the Frente Farabundo Martí para la Liberación Nacional (FMLN, Farabundo Marti National Liberation Front). In 1981, the Front began an armed insurrection that sought to overthrow the Salvadorian Government. This arm struggle led to a very brutal civil war that lasted from 1980-1992. The war left a toll of 75,000 dead (1.4\% of the total population). The main causes of this war were the popular discontent with the repressive military dictatorship and the huge economic gap between the upper and lower classes. In 1992 the Right-wing government of ARENA (Alianza Republicana Nacionalista, Nationalist Republican Alliance) and the FMLM guerrillas signed a peace agreement in Chapultepec (Mexico). The guerrilla was dismantled and transformed into a political party (Zinecker 9-19). The human rights violations and the thousands of cases of missing people collected by the Comision de la Verdad para El Salvador have received the proper attention by the authorities and justice has not been served to this date because the "General Amnesty Law " of 1993 warrants impunity of those responsible of war crimes for both parties (ibid 72).

ARENA (Alianza Republicana Nacionalista, Nationalist Republican Alliance) is a conservative and neoliberal political party. It was founded in 1981 by a military sector in order to create a counterweight to the guerrillas and was in government from 1989 to 2009. Since 2009 is an opposition party since the FMLN won the elections. For more information on ARENA refer to Henriquez et al., "Diputados disidentes." 
Excélsior (Mexico), and the journals Proceso, Casa del tiempo, Limite sur, Estrategia and La brújula en el bolsillo (Mexico).

His first literary work was La margarita emocionante, an anthology of poetry, published in 1980. Between 1986 and 1987, he wrote his first novel, La Diaspora, which speaks of the experiences of Salvadorian exiled in Mexico. The novel denounces the violence of the civil war in general and the role of the Left wing in the armed struggle. Castellanos Moya returned to El Salvador after the war ended and took a major role in the creation of the first post-war newspaper, El Frente, of which he was the director.

He published his second novel, Baile con serpientes, in 1996 a very violent novel with fantasy elements, style that incidentally is not repeated in his later work. Castellanos Moya published El asco-Thomas Bernhard en San Salvador in 1997, where a migrant (Edgardo Vega) returns to San Salvador and tells his old friend (Moya) of the disgust that the country's produces, politics, food, beer and especially the way people think produce in him. Paying tribute to the Austrian writer Thomas Bernhard, the novel is characterized by verbal aggression and the main character paints an overall negative picture of the Central American country. After the publication of El asco, the Salvadorian writer received death threats and for this reason he had to leave the country. He then traveled to various places in Europe and America, before settling back in Mexico City, where he obtained the position of Chief Editor of the weekly magazine Millennium.

Since the success of his novel El asco, Castellanos Moya has received a lot of recognition as an established writer. I must make the notation that many of his characters reappear over and over in his novels. In La diabla en el espejo (2000), an upper-class woman, Laura Rivera, narrates and investigates the circumstances of the murder of her 
best friend, Olga Maria de Trabanino. The murderer, Robocop, appears in the novel, but his actions account for very little. However, in El arma en el hombre (2001), Robocop plays a major role. Castellanos Moya managed to gain international notoriety with these novels. In these two novels - which are the focus of my literary analysis in this section of my dissertation-, Castellanos Moya reveals the arrogance and disdain of the wealthy class and the ignorance, poverty and emotional violence of former soldiers. The Salvadoran writer in these novels creates a complex picture of the postwar Central American nation.

Insensatez (2004) is Castellanos Moya's sixth novel. The plot of the novel takes place in an unnamed country where a Salvadoran journalist is charged with drafting a report on the indigenous genocide that took place during the war years. In Castellanos Moya's most recent novels, the narratives are centered in the experiences of several generations of the Aragon family, whose members make their appearance in Donde no estén ustedes (2003), in a subplot of Desmoronamiento (2006) and in Tirana Memoria (2008). The Aragón clan is a politically divided family, along with the Honduran family Mira Brossa the family witness crucial moment in the history of El Salvador of the twentieth century like the failed military coup of $1944,{ }^{36}$ the 1969 Soccer War, ${ }^{37}$ Civil

${ }^{36}$ Maximiliano Hernandez an authoritarian General Martinez became president of El Salvador after a military coup overthrew the freely elected government of Arturo Araujo in 1931. The Salvadoran legislature confirmed Martinez as president the following year, and he was elected to a four-year term in 1935 and a six-year term in 1939. He was a Right-wing dictator who admired the Italian and German fascism. He stayed in office longer than any previous Salvadoran president. During his presidency, Hernandez ordered the massacre of thousands of peasants and political dissidents. In early 1944, Martinez suspended the constitution and declared himself President of the Central American nation for a third term without an election. A revolt led by military dissident failed to overthrow his dictatorship in April of the same year, but on May 5, 
War, 1980 to 1992, and the postwar era. Castellanos Moya besides novels also writes short stories in which the themes of violence, discrimination, military abuse and death, all social evils brought by social injustice and war, are at the core of the narratives. I must also point out that in his production of short stories several of his characters reappear sporadically in multiple works, that is the case of the fictional private detective Pepe Pindonga.

\section{III.5. Literary Postmodernity in Castellanos Moya's Narrative}

The following sections of my study of Castellanos Moya's literary project will highlight his link to the postmodern literary expression as presented in his novels $L a$

1944 a group of college students organized a general strike that brought most of the economy and civil society to a stop, and the protest rallies that followed forced Martinez to flee the country on May 11, 1944. For more information on the topic, see Patricia Parkman, Nonviolent Insurrection in El Salvador: The Fall of Maximiliano Hernández Martínez. Tuscon: U. of Arizona Press, 1988

${ }^{37}$ The Soccer War of 1969 was a short war between El Salvador and Honduras. The reason for the political tensions between these two Central American countries grew out of the hostile sentiments of the Salvadoran people who were unhappy with how Salvadoran migrant workers in Honduras were treated, especially after Honduras began expelling thousands of Salvadoran illegal immigrants in the late 1960s. At the time both nations were in the qualifying games for the 1970 FIFA World Cup soccer tournament, and when the two teams played each other, the soccer games took place with the backdrop of heightened tensions between the two nations. The war broke out in July 1969 with Salvadoran military forces punching quickly into Honduras. The short war ended with a cease-fire arranged by the Organization of American States (OAS), and El Salvador withdrew its forces from Honduran territory by August 2, 1969. For more information on the topic, see Jay Mallin, Salvador-Honduras War, 1969. University Review. August 31, 2004. 
diabla en el espejo and El arma en el hombre. I will focus my argument on specific conditions of their productions. My intention is to demonstrate how Castellanos Moya reconstructs in the literary space the violence lived in El Salvador in the late 1980s and early 1990s. To do so, he makes use of the new literary paradigm which foregrounds the individual desires, passions and struggle for survival in contemporary times. In the following sections, I will focus the discussion on some of the formal techniques and properties that Castellanos Moya incorporate in La diabla en el espejo and El arma en el hombre and analyze how they parallel the techniques of postmodernist formal literature.

Horacio Castellanos Moya like Dante Liano and Sergio Ramirez blurs the boundaries between elements of fact and fiction within his narrative and by doing so he contributes towards creating skepticism and lack of coherent certainty of reality. The violence of criminal actions carried out by individuals who had connections to the military force and to the government of El Salvador of the late 1980s and 1990s serve as evidences in La diabla en el espejo and El arma en el hombre to the prevalent difficulty of determining what is real and what are actual fabrications of corruption. Both novels are narrated in the first person and in an oral style very much like the one used in testimonial narrative of the previous literary period in Central American letters. The narrative style employed by the novelist is a direct reference to the testimonial genre. As I have noted earlier in chapter two of this work, the testimonial discourse was privileged in the narrative produced in the isthmus especially when it dealt with the relationship between history/reconstruction of memory to signal in the literary realm the human rights abuses and the violence and oppressions of the wars against the political regimes that oppressed many of the Central American nations. However, in both of Castellanos 
Moya's novel the reference to the testimonial account serves as a postmodern parody that allows a panoramic view of the state of affairs and indicates the individual's skepticism toward the governing and economic system that prevailed in El Salvador after the many years of violent wars.

Castellanos Moya's protagonists/narrators, unlike the narrators of testimonial accounts, are works of fictions and not real individuals telling their experiences in times of social tension. As artistic creations, these characters portrait the author's will to speak and behave in whichever way the novelist desires them to do so. Castellanos Moya's narrators, unlike the writer of a testimonial account who accounts for factual eyewitness events in the testimonial narrative, are inventions that are less than reliable because they don't fully understand their place in a chaotic society devastated by a long violent war. If they lack the capacity to understand the driving forces of their society, they can't be reliable sources of the truth. Even though at times both of Castellanos Moya's protagonists seem to fully believe in the system of government that runs their countrythey both adhere themselves to the Right Wing ruling party-, at times, they also find themselves doubting the reliability of the actions of the governing institutions and everyone else around them, including their own. They are fully aware that individual desires and passions are the driving forces behind everyone's actions, including their own, in a chaotic society like the one they live in. The hesitations of these characters can be noted in the following passages from the novel. The first one depicts how hard it is for Robocop to accept that the war can be over just by a simple act of signing peace agreements. After seeing the corrupt and violence forces by which the war was fought, he can't comprehend that both sides can come to an understanding through diplomatic 
means. The second quote is from La diabla en el espejo and illustrates the despair that the protagonist feels towards the end of the novel because she feels that crimes like the assassination of her best friend are perfect examples of a corrupt estate in which everyone, including herself, is capable of committing crimes in order to satisfy individual desires and passions:

Convertirme en civil fue difícil. Supimos de nuestra inminente desmovilización desde que se decretó el cese de fuego. No lo creí. Las negociaciones me parecían una estratagema, por lo que supuse que toda esa palabrería de los Acuerdos de Paz constituían una estratagema, por lo que supuse que entraríamos nuevamente en combate, para acabar de una vez por todas con la subversión. (El arma en el hombre 12)

No me extrañaría que Handal ahora tratara de desviar la investigación hacia mí. Para obligarme a callar todo lo que sé. Fácil, niña: puede decir que Robocop fue contratado por ese mayor no sé qué, por órdenes mías, porque yo me estaba disputando a El Yuca con Olga María. Esos malditos son capaces de decir que yo mandé a asesinar a mi mejor amiga en un pleito por un hombre. .. . Te lo juro: son capaces de afirmar cualquier cosa: que yo le tenía envidia a aquélla, que estoy bajo tratamiento siquiátrico, que ella era como un alter ego del que me tenía que deshacer, que El Yuca siempre ha sido el hombre de mi vida y no me hacía caso por culpa de Olga María, que le guardaba resentimiento porque ella destrozó mi matrimonio con Alberto, que yo la odiaba porque siempre me trató con desprecio, cualquier tontería. Me da rabia pensar en todo el 
dinero que se gasta manteniendo a esa recua de policías corruptos. Ahora verás que hará todo lo posible por desviar la investigación del crimen de Olga María de aquellas pistas que conducen hacia las operaciones fraudulentas de Alberto y el Toñito Rathis. (La diabla en el espejo 180) Laura comments towards the end of the novel depict the state of distressed she finds herself after falling victim to a nervous breakdown caused by Olga María's killing and the escape from prison of her killer. Even though her mental state is severely troubled and can't be at all reliable, her comments in the about passage of the novel illustrate the many possible reasons behind her best friend's murder. Among them, it depicts the theory that she might be the person who sent to kill her best friend as an act of revenge and jealousy. The excerpts from both novels also show the criminal acts carried out by important economic leaders and political figures of the new socio-economic system in the Central American nation. Robocop's doubts about the peace process can be seen as mistrust in the country's government institutions. Laura's last comments in the above mentioned passage signal how two major economic leaders of El Salvador are in fact major criminals. These excerpts from the novel exemplify the postmodern condition of the level of difficult of determining the actual truth in a society as corrupt and unstable as El Salvador during the period right after the war. Castellanos Moya's two novels are perfect examples of the new postmodern form of noir narrative being produced in Central America, for they incorporate the use of the noir narrative element of violence and corruption to portray individuals' desires, passions and struggle for survival and to depict the generalized uncertainty of the truth. 


\section{III.5.1. Corruption in Castellanos Moya's La diabla en el espejo and El arma en el}

\section{hombre}

The theme of corruption goes hand in hand with the theme of violence in Castellanos Moya La diabla en el espejo and El arma en el hombre. He recreates the historical period following the years right after the Salvadoran civil war of the 1980 in these two novels. The novelist, through the use of both of these themes in his narratives, sketches how perpetrators in all sectors of society get involved in criminal actions in order to have access to easy money in a society devastated by a civil war. Castellanos Moya by the incorporation of both of these themes in his fiction writing creates a very strong social critique of the post-war Salvadoran society as a way to address the failed revolutionary project to provide social equality to all sectors of society. This feature in Castellanos Moya's novels exemplifies the new literary trends in Central American letters. The novelist evaluates how little improvement was achieved after the many years of war violence. At the beginning of La diabla en el espejo, Laura describes Olga María as a perfect role model of what a society daughter, wife and mother should be and with disdain rejects the questionings of Olga María's character by the police officials in charge of the investigation when they start inquiring about the likelihood that Olga María might have fallen victim to her own secret and immoral endeavours. Laura is also a well-to-do woman whose prejudices for anyone outside her own upper-class economic circle and anyone who is not affiliated to the Right wing political party that controls the country is constantly noted throughout the novel. The reader is capable of having a clear image of Laura's ideology from the very first pages of the novel when she narrates the stress she 
undergoes when she is question by police investigators as to the reasons why anyone would want Olga María dead:

... el tal subcomisionado Handal me dijo que quería hacerme unas preguntas, a solas, que si yo había conocido tanto a la victima, si había sido su mejor amiga, entonces tal vez podría ayudarle, para que él pudiera seguir algunas pistas que explicaran los hechos. Sospeché que alguna cochinada se traía entre manos, esos tipos son groseros, morbosos y sucios, los de la policía, siempre lo he sabido, por eso me puse en guardia, para que no creyera que iba a sorprenderme de buenas a primeras. $\mathrm{Y}$ sucedió lo que temía. El subcomisionado preguntó si yo sabía de algún enemigo de Olga María o de Marito, de alguna deuda considerable que los estuviera mortificando, de algún empleado que los hubiera amenazado luego de ser despedido o, conto respeto -y así dijo el muy sinvergüenza: "Con todo respeto"-, si Olga María tenía alguna relación extramarital, algún amante despechado, alguien que quisiera hacerle daño. Y entonces sí me encabroné: le grité que era un verdadero patán un tipo sin sensibilidad, cómo se le ocurría que yo le iba a contar la vida privada de mi amiga a un cualquiera como él, de dónde había sacado semejante idea, sospechar de una persona tan honesta, tan recta, tan entregada a su familia y a su trabajo como Olga María era una canallada sin nombre, ella no tenía enemigos, a nadie se le ocurriría querer matarla, tenía que haber sido una equivocación o la obra de un demente. Casi lo hecho del apartamento a empujones, por tremebundos, por sarnosos. (La diabla en el espejo 17-18) 
Laura's bourgeois comments and actions represent the neoliberal post-war ideals rooted in present day Central America, ideals that clash with the utopian visions of the revolutionary years and with the literature produced during the époque. The tendency in the contemporary Central American literary project is significantly different from that of the 1970s and 1980s. After the political struggles in the isthmus came to an end in the early 1990s, the narrative fiction that was characterized by the testimonial and politically committed literature that sought to contribute to the fight against oppressed dictatorships gave way to a literature that is well marked by a disenchantment with the revolutionary dreams and with the neoliberal Right wing governing systems. Beatriz Cortez calls this new literary trend in the Central American letters as an "estética del cinismo," which she defines as "una estética marcada por la pérdida de la fe en los valores morales y en los proyectos sociales de carácter utópicos" (2). This new literary paradigm focuses on portraying the individual desires, passions and struggles for survival in the violent present day Central American nations. Horacio Castellanos Moya has stated that this new form of literature presents the "cultura de la sobrevivencia, del presente inmediato, del mañana incierto y poco probable" that the Central American region faces nowatdays (Horacio Castellanos Moya, Recuento de incertidumbres 45). These post-war narratives focus on highlighting the individual's struggle for survival in violent societies with a grim future. Through Laura's narrations the reader is capable of reconstructing a panoramic view of the social inequalities that create an abysmal gap between the upper and lower social classes. The revolutionary movement in El Salvador not only sought to overthrow the corrupt and oppressive regime and reinstate a more democratic government; it also attempted to establish a form of socialist government that would guarantee the economic 
stability of all the members of society. Castellanos Moya's protagonist in La diabla en el espejo is a member of the Right wing who is only preoccupied in guarding her own self-interest and do not seek to work for the common good for the people of her country. Through his protagonist, Castellanos Moya makes a social critique that foreground the sense of dissolution with the outcome of the revolutionary struggles and its failed social projects which is another aspect of the new noir narrative being produced in the isthmus as I have suggested through my analytical work.

Through Laura's own narration the reader learns that corruption is one of the key motivators for many of the key characters in the novel. The image that Laura creates of her dead friend at the beginning of the novel is far from the truth. Olga María had engaged in multiple extra-marital affairs with several key figures of the elite group that controls the economy of El Salvador. Laura, who at first is upset by the police investigators assumptions regarding Olga María's "remarkable" moral standards, at times helped facilitate the victim's romantic encounters with several of her lovers. The police examination of this aspect of the victim's life suggests the hypothesis that Olga María might have been murder by a jealous lover who did not want to see her with anyone else or because she came across vital information that might endanger a potential illicit business transaction. The reasons behind the actual killing of Olga María are never revealed. However, eventually, Laura comes to believe that the murder of her friend had to have been the result of Olga María's wrong doings. Towards the end of the novel, Laura fear for her own safety and feels that she will also fall victim to the same destiny as her friend, for she too has acted in very questionable manners, as many of the characters in the novel do. 
Laura's inquiry about her best friend's murder makes her aware that in a country devastated by the violence of war and criminality everyone is engaged in some way or another in illicit and immoral acts. Laura at one point in the novel, learns that El Yuca, a young business entrepreneur of the upper class and who is likely to become the next presidential candidate of the ruling Right wing party, is a drug addict who has lost total control of himself and can't no longer be fully functional without being under the influence of narcotics. Also, Laura learns about a fraudulent investment scheme that bankrupts the financial institution headed by Laura's ex-husband, Alberto, who was also another of Olga María's secret lovers. Alberto and his business partners are forced to face justice, but the details of the fraud are never revealed. As Laura narrations of these events continue, there is only the suggestion that the disappeared money was used to either help promote El Yuca's presidential campaign or used to pay off a debt that Alberto and his business partners had with the Cali drug cartel.

Another example of the lack of moral standards and corruption in both novels, is the way in which Olga Maria's killer, Robocop, an ex-military who was trained as a member of an elite group of an army special force, was able to escape from prison because the very same authorities that had him under custody helped him walk free from prison. All in an attempt to continue covering the truth about who is truly responsible behind Olga María's killing. All this corrupt acts that are brought about by the violent nature of the environment in which Laura sees herself living once she starts inquiring about the truth behind the murder of her friend, provokes in her a sense of despair and uncertainty, and she states: "Yo ya no le puedo creer nada a nadie" (La diablal en el espejo 137). After Robocop escapes from prison, Laura falls into a paranoia and begins 
to believe that Robocop is after her and will not rest until he kills her. Laura ends up being admitted in a mental clinic after suffering a severe nervous breakdown.

Through Laura's actions and comments in the novels, Castellanos Moya establishes an analysis of how little improvement was made to bring about the social changes for which the wars of the 1970s and 1980s was fought. As we know, the utopian dreams of the revolutionary years came to a crash after many years of the violent war in the early 1990s. The neoliberal government and its free-market economic system do not provide the answers to remedy the chaotic conditions of an unstable and decomposing society that is characterized by violence and corruption, as it can be seen in Castellanos Moya's La diabla en el espejo and El arma en el hombre.

III.5.2. Violence in Castellanos Moya's La diabla en el espejo and El arma en el hombre In the previous sections of my analysis of Dante Liano's novel El hombre de Montserrat, I discussed how the Guatemalan novelist makes use of the noir sensibility, most specifically the sentiment of pounding despair typical of an environment prompt to criminality, in order to create a portrait of the fatalistic era of the war years in Guatemala during the 1980s. In this section of this dissertation, I will focus my inquiry to study the presence of the same noir sensibility mentioned above in the incorporation of the element of violence in Horacio Castellanos Moya's La diabla en el espejo. My intention is to note one important difference between Liano's and Castellanos Moya's incorporation of the theme of violence in their novels. Whereas the violence encompassed in Liano's novel comes as a result of the political struggle between two opposing political forcesthe National Guatemalan Army and the revolutionary force that opposed the governing 
system - in Castellanos Moya's novels violence stands as the main dynamic for criminal perpetrators to obtain money in order to survive in the very harsh economic conditions in a society devastated by a civil war. In the article entitled (De)formacines: violencia y narrativa en Centroamérica, the literary critics Werner Mackenbach and Alexandra Ortiz Wallner point out the shift that occurred in the treatment of the theme of violence in the Central American literary project of the last three decades of the XX century. According to them:

A manera de recapitulación podemos afirmar que durante las décadas de 1970 y 1980 dominaba en las representaciones literarias en Centroamérica un concepto de violencia basada en la denuncia de la opresión política, económica y social, ejercida principalmente por gobiernos autoritarios y militares, así como en la justificada contraviolencia colectiva de los oprimidos y subalternos. A partir de los años noventa se constata cómo la representación y funcionalización de la violencia se distancia de este sentido político-ideológico así como del imaginario mítico-revolucionario para dar lugar a nuevas presencias, formas y percepciones de la violencia —en tanto dimensiones y representaciones de un cambio fundamental de la sociedad-, para las cuales el orden anterior resulta insostenible, a la vez que es profundamente transformado. (85)

The new shift in the paradigm of the theme of violence in the Central American literary project of the last 20 years moved away from the established model in which violence was part of the narratives of the armed struggle and was justified as part of the 
war against social injustice. In El hombre de Montserrat, one can see this transition in the treatment of the theme of violence in the new narrative production. Even though in the novel the violent clash between the military and the guerrilla is present throughout the narration, the reader also witnesses the presence of violent attacks against individuals who do not have close connections to the military or the government, but still fall victims to violent criminal acts because of economic circumstances. Marcos Barnoya, the dead man found at Montserrat, and of Ramón, Lieutenant García's brother in law were both murdered by perpetrators whose main objective was to obtain easy money.

The theme of violence in Horacio Castellanos fourth novel La diabla en el espejo appears as a mean to access easy money and is presented in the novel by the brutal murder of a woman of the upper-class Salvadoran society. The victim is cruelly murdered in front of her two daughters by an ex-military turned criminal. The novelist recreates the violent years of the post-war period lived in El Salvador through the narration of the murder of Olga María, daughter of a prominent businessman and who has close connections to the Right wing elite class that runs the economic sector of the Central American nation. The novel is entirely narrated by Laura Rivera who is also the protagonist of the novel. She claims to have been the victim's best friend and to have known her better than anyone else. Laura in her narration attempts to connect loose knots in order to shed some light as to who could be behind this apparently senseless murder and to the reason why her best friend was killed in such a brutal manner. Laura is incapable of finding the whole truth behind her friends killing, but in her attempt to clarify the mystery she unveils the shady illicit manners in which prominent member of 
the Salvadoran elite carryout their business practices in order to keep their assets growing.

Castellanos Moya's fifth novel is El arma en el hombre. The novel can be read as a parallel reading companion to La diabla en el espejo. Both novels, share several connecting points and through the reading of both novels the reader is able to reconstruct a panoramic image of the violence that governed El Salvador during the period right after the peace agreements where signed and the arm struggle ended. While in La diabla en el espejo the reader learns about the uneasiness and anxieties experiences by a victim of the violent and the unstable social order that reign in the Central American nation-through the narration of a well to do homemaker-in El arma en el hombre, the reader learns about the social disorder brought by the extreme violence of the post-war years in El Salvador through the narrations of a victimizer. According to Rafael Lara Martinez both novels can be read as part of the same narrative work: "Las obras pueden leerse aisladamente; pero existen múltiples conexiones que sugieren una lectura conjunta. Los dos héroes principales—Laura Rivera y Robocop—aparecen desdibujados y sin interioridad en el medio de la otra novela" (12). The element that units both novels is the violent murder of Olga María. In the first novel, the killing of Olga María deploys the action of the plot. The killer is Robocop an ex-military of the Salvadoran Army's elite who was trained by US Special Forces to eliminate counterinsurgency battalions and was part of the horrific murder of Jesuit leaders of the University of Central American in 1989. The specially trained soldier once the war was over became literally a killing machine hired by the Salvadoran organized crime. In the second novel, Olga María's murder is only one of the many crimes committed and narrated by the protagonist of the 
novel. The reasons for Olga María's murder are never clarified in any of the two novels. Even Robocop ignores the true reasons as to why he is hired to kill his victim.

Robocop in both novels appears as a very violent figure. He is presented as a fearless man who puts to practice the special skills he learned in his military training to commit a series of criminal actions that depict the violence that reign the streets of San Salvador during the 1990 in both novels. After killing Olga María and committing various criminal acts, the reader learns in both novels that he is arrested, and is able to escape from prison with the collaboration of the authorities. This suggests that Olga María's death was ordered by one of her acquaintances with close connections to the government. Robocop, after escaping custody, is picked up by other members of his criminal gang — which is led by Major Linares_-Robocop's former commanding officer. After his escape from prison, the very same individuals who helped Robocop flee San Salvador try to kill him in an attempt to silence him for good in the event the police try to get to him again and interrogate him about the death of Olga María. Robocop is able to outsmart his perpetrators and manages to escape alive from the attempt to kill him. He eventually reaches a poppy plantation owned by a drug lord with connections to the government. He works as part of the security team along with other war veterans of the Central American wars of the 1980.

Almost at the end of El arma en el hombre, soon after Robocop starts working in the poppy plantation, he is severely injured in an anti-drug operation led by U.S. troops. He is taken to San Isidro, Texas and learns that "una esquirla me había volado parte de la frente" (El arma en el hombre 130). Robocop is offered a deal by the U.S. anti-drug officials and he has to choose either to return San Salvador and face justice for the violent 
crimes committed or remain in the U.S. or collaborate with the authorities in its efforts to bring down a major drug cartel that operates in the Central American Nation. The U.S. authorities in return offer to reconstruct his severely injured face and to give him a new identity. Robocop's decision in the novel is not stated, but the reader can imply that he chooses to collaborate with the U.S. authorities. After all, he had collaborated with them in the past while fighting the counterinsurgents. Robocop was part of a Right wing military force that received special assistance from the U.S. Government. Just like Dante Liano in El hombre de Montserrat, Castellanos Moya, in La diabla en el espejo and in El arma en el hombre, makes use of narrative features that derive from the noir tradition - most specifically the sentiment of pounding despair typical of an environment prompt to criminality and violence - in order to create a portrait of the fatalistic era of the post-war years in El Salvador. Castellanos Moya in these novels does not highlight the actual description of the murder of Olga María. The killing in the novel serves only as the pretext for the author to transfer the historical reality of the Central American nation following the years right after the peace agreements that ended the war. Castellanos Moya's novels - like the other two novels analyzed previously in my workforefront the postmodern concern for historiography. The author achieves this postmodern writing feature through the formation of complex relationships between the extra-literary reality and the fictional representation of reality. The Salvadoran novelist in La diabla en el espejo and El arma en el hombre, foreground the theme of violence as a way to recreate in the narrative space the violent outcome of individual interests deployed by the desire to obtain easy money in a country devastated by a long and violent war. 


\section{III.5.3. Aspects of the Noir Narrative in La diabla en el espejo and El arma en el hombre}

The most outstanding elements of the noir narrative style that I encountered in Castellanos Moya's La diabla en el espejo and in El arma en el hombre are the direct writing style, the gritty realism of the "hardboiled fiction" and, of course, the mystery behind the killing of Olga María. In both novels, the social landscape of contemporary El Salvador looms behind an underworld of crime. The movements and actions of the main characters through the city of San Salvador help reconstruct in the fictional space the reality of present day San Salvador. The Salvadoran city serves as the perfect scenario in which the author depicts the violence lived during the period right after the signing of the peace process. The constant allusion to the use of weapons, organized crime and death in both novels form part of the realistic manner in which the author recreates in his fiction writing the distrust, paranoia and fear lived in the urban center of San Salvador as we can note in the following excerpt from the novel:

A media tarde de un viernes, a la entrada de Ciudad Delgado, nos apropiamos de un Golf nuevecito. La vieja que lo conducía balbuceó que por favor no la matáramos. Bruno se puso al volante. La dejamos dos calles adelante y enfilamos hacia mi habitación. Metimos al auto los dos fusiles AK, envueltos en una bolsa de lona, y me guardé un par de granadas en mi chaqueta de mezclilla. Enrumbamos hacia el poniente de la ciudad, donde viven los ricos. Subimos por el Paseo Escalón. . . . Le indiqué a Bruno que se metiera en una de las calles laterales, antes de llegar al redondel Masferrer. Desembolsé los fusiles .... Hacia el final de la calle, donde topaba con una barranca, había unas casas más chicas, sin 
muros ni vigilantes. Una sirvienta, manguera en mano, regaba el césped, con la puerta de la cochera entreabierta. Salí de un brinco, en carrera, con el fusil por delante. Le dije que si no obedecía era mujer muerta. (24-25) This is the first of a very long list of criminal acts perpetuated by Robocop in El arma en el hombre. His inventory of illegal weapons, collected during his military career, and the training that he received in the eight years that he served in the military force transform him into a killing machine that only obeys the orders of organized crime. In both novels, the direct style in which the chaotic streets, the slums, saloons and brothels where Robocop plans and operate his criminal actions are depicted with the realism inherited by the noir tradition as we have observed in the previous citation.

The reality that emerges from the narration of the actions of characters like Robocop and Laura in both novels distinguishes the contemporary times of Central American cities like San Salvador. Both novels indicate how Central American cities have become ravaged by violence and crimes that have no meaning or justification of any kind as I have noted in the quotation above. Likewise, through these descriptions of the city of San Salvador in Castellanos Moya's novels the reader can also observe specific aspects of the popular culture. The socio-cultural changes suffered in El Salvador after the peace signing process points to the country's entry into the new consumerist society. This notion is very well represented in both novels by the detailed descriptions of the chaotic city of San Salvador. In the novels, Castellanos Moya does not omit details that provide a clear picture of the popular culture, the food and the leisure time activities of the well to do, middle and lower classes. Only through the use of the noir narrative style Castellanos Moya manages to capture in literary creation the contemporary cultural 
phenomena that distinguish the current socio-economic situation of a country like El Salvador as the reader can observe in the following comments made by Laura regarding a new restaurant in town.

Me encanta este lugar, niña; segunda vez que vengo. Hace como un mes estuvimos en esta misma mesa con Olga María. Lo que me gusta es este ambiente europeo, una se siente como si no estuviera en San Salvador, sólo le falta el aire acondicionado para ser perfecto. Prefiero este lado que da a la calle, cada mesa en su balconcito. La zona no me termina de convencer; mejor si estuviera por las colonias decentes donde una vive, pero tampoco está tan mal. Mirá cuánto carro. Y ese centro comercial de ahí en frente, qué feo, un adefesio, para sirvientas ¿Sabés que la dueña es la Mirna Leiva, aquella compañera nuestra de la Escuela Americana? No la veo ahorita por aquí.... Vivió muchos años fuera, después del gran problema. ¿Te acordás que la metieron presa por comunista? Pobrecita. Estuvo en Madrid varios años. (81)

Both novels are written in the noir genre style and besides the direct writing style and the gritty realism of the violence and the everyday reality lived in present day El Salvador the novels as true descendants of the noir tradition incorporate the element of suspense. The mystery plots keep the reader interest in wanting to find out who was behind the killing of Olga María and which were the motives behind this brutal act. $L a$ diabla en el espejo is the narration of a sequence of events that begin with the killing of Olga María. Laura, the narrator, communicates all of these events to a mysterious interlocutor whom she calls "niña" from the beginning of the novel: "No es posible que 
una tragedia semejante haya sucedido, niña" (11). The uncertainty about this character helps maintain the sense of mystery typical of the noir narrative. As expected in a good mystery plot novel, the reader learns the true identity of this character at the end of the novel. As it turns out, it is Laura herself. The reader comes to find out that Laura has not been mentally stable since the death of her friend as noted in the following lines where she describes how her mother is concerned about her mental state of being: "... dice que estoy grave de los nervios, que no me encuentro bien de la cabeza, que desde que Olga María murió permanezco alterada, que me la paso hablando sola, que siempre salgo sin compañía como si no supiera que ando con vos" (182). Thus, Laura narrates the events after her friends murder to a part of herself that she recognizes as being someone real. This also evidence how Laura falls victim to the violent criminal acts lived in El Salvador during the years immediately following the end of the civil war. The reader, at the end of both novels, never finds out who exactly was behind the killing of Olga María, and which were the true motives for her murder. There are only indications of multiple hypotheses of the reasons behind the murder. One of these hypotheses points toward Laura as the person behind the murder. Through her narration, Laura reveals how Olga María had engaged in extramarital affairs and some of them were even facilitated by Laura herself. What's interesting about Olga María's affairs is that many of her lovers were also Laura's. Olga María even had a sexual encounter with Laura's ex-husband. In the novel, it is implied that Laura might be the intellectual murderer behind Olga María's killing as an act of revenge. Though, this is never proven. The mystery is never resolved in either of the two novels. Both of Castellanos Moya's novels analysed in this part of this dissertation do not fit neatly within the generic classification of the detective or noir 
narrative; however, they allude to and play with the conventions of the genre. The insidious sense of corruption, decay and disillusionment— brought about by violence and criminality of the present day chaotic reality lived in countries like El Salvador, and the realistic way in which they are described by the author - found in these murder mystery novels earn them a place into the category of what I recognize as the new noir Central American literature.

\section{III.6. Conclusion}

Dante Liano’s and Horacio Castellanos Moya’s literary projects are characterized by their strong desire to transfer into the literary sphere the reality lived in Central American countries like Guatemala and El Salvador. To accomplish this task, these writers make a revision of historical events and of the social injustice lived in these wars affected countries. Both novelists make use of the noir sensibility and blend it with postmodern writing technics in order to recreate dark violent periods of their countries' histories. Through their work, these two novelists denounce the abuses of the military forces and the criminal actions of many members of their societies. In their fiction writing these two authors foreground the individual desires, passions and struggle for survival that characterize the existence of many in contemporary times. While analysing Dante Liano's El hombre de Montserrat, I pointed out that the writer highlights the theme of violence as a way to recreate in the narrative space the hardship of the internal political struggles of the Guatemala of the 1980s. In this chapter, I also pointed out that Horacio Castellanos Moya's incorporates the themes of violence and corruption in both of his novels, La diabla en el espejo and El arma en el hombre, in order to sketch-out how 
perpetrators in all sectors of society get involved in criminal actions as an easy way to have access to easy money in a society devastated by a civil war. Both of these Central American novelists through the incorporation of the themes of violence and corruption in the literary productions that I have analysed in this chapter create very strong social critiques of the post-war Guatemalan and Salvadoran societies as a way to address the failed revolutionary projects which hoped to provide social equality to all sectors of society. Liano and Castellanos Moya make use of the noir sensitivity in their novels in order to recreate in the literary atmosphere the gloom, agitation and fear associated with the sense of living in an environment where violence is constantly present and to depict the sociopolitical circumstances under which their fictionalization of reality emerged. 


\section{CHAPTER IV}

\section{THE CENTRAL AMERICAN LITERARY TRADITION OF PATRIOTISM IN RAMON FOSECA MORA'S EL DESENTERRADOR}

\section{IV.1. Ramon Fonseca Mora’s Literary Project}

The Panamanian writer Ramon Fonseca Mora is a prolific author whose literary endeavors are combined with a successful law practice. Fonseca Mora was born in 1952 in Panama City, Panama. He graduated from the University of Panama and the London School of Economics with degrees in Law and Political Sciences. He has worked for the United Nations and is a senior partner for the Panamanian International Law Firm Mossack, Fonseca \& Co. Fonseca Mora has been an active member in several civic organizations that promote the intellectual, civic, cultural, social and moral welfare of his community. From 1995-2005, he served as a board member of the Children's Hospital in Panama City. His love for literature and his civic concerns have led him to become one of the founders and the first president of the Panamanian Chamber of Books, a private nonprofit foundation that promotes literature in Panama. Fonseca Mora has published five novels: El desenterrador (2007), Soñar con la ciudad (2001), Ojitos de ángel (1999), La ventana abierta (1996), La danza de las mariposas (1995); several collections of short stories: La Isla de las iguanas y otros relatos (1995), El político viejo (1992), El amor de la abuelita (1991), Justicia (1991); and a few plays: Ojitos de ángel (a theater adaptation of his novel by the same title, 2000) and - 4 Mujeres vestidas de negro (1996). He has also published law review articles and cultural notes for newspapers and journals. 
Fonseca Mora is one of the most representative fiction writers in Panama's contemporary literary circles. Readers in and outside of the Central American nation have received his narrative works with great acceptance and he has won many literary awards, such as Premio de Novela Ricardo Miró—Panama's most prestigious literary recognition —in 1994 for La Isla de las iguanas y otros relatos and in 1998 for Soñar con la ciudad. His novels are very well developed and his characters and argumentative material are very close to the everyday reality lived in contemporary times in Panama but nevertheless he sometimes uses elements of magic realism. These elements, inspired by the tradition of fantasy literature flow with much spontaneity in the development of the plot and do not interfere or reduce the quality or content of his creative work. This is the case, for example, in one of the scenes from Fonseca Mora's novel La danza de las mariposas when a group of butterflies come out of a book that falls to the floor and invades the protagonist (Anselmo)'s office after he locks himself up when he is suffering from heartbreak because his beloved no longer wants to be with him. Perhaps a better example of the presence of an element of fantasy in his literary creation is the incorporation of a demon that hunts Urbano, the protagonist of El desenterrador, through the last segment of the novel. Thematically speaking, Fonseca Mora's literary project reveals a constant obsession for including in his literary spaces the desire to uphold high moral standards and justice in a contemporary society that seems to be more preoccupied with gaining economic success and distancing itself from its moral standards - as evidenced especially in the relationship between Urbano and his son, Jorge, in $E l$ desenterrador. In his fiction, Fonseca Mora incorporates characters that are concerned with the well being of humanity, as it is the case in his novel Ojitos de ángel where the 
spiritual richness of a young dying girl is juxtaposed with the greed and arrogance of a rich and successful businessman. Fonseca Mora's narrative project is set in Panama, a business oriented society radically different from the rest of Central America. The novelist incorporates in his work universal themes that allude to the new literary paradigm in Central American letters. This is a paradigm that has put less emphasis on the elements of costumbrismo and the themes of national, cultural and geographical identity that very much characterized the literature of the Central American isthmus until very recently. Ramón Fonseca Mora’s narrative, like the narrative of Sergio Ramirez, Dante Liano and Horacio Castellanos Moya's, underlines the interest for the multiple social changes lived in the region.

\section{IV.2. Ramon Fonseca Mora's Literary Postmodernity}

Ramon Fonseca Mora makes use of multiple writing features of the postmodern modality to recreate in his narrative the socio-historical reality of the last decades of the $20^{\text {th }}$ century and the first decade of the $21^{\text {st }}$. In this regards, his writing technique shows points of connections with the multiple characteristics utilized by the other Central American writers whose work I have analyzed in this dissertation (Sergio Ramirez, Dante Liano and Horacio Castellanos Moya). For example, one of the postmodern characteristics identified in this analysis as being incorporated by contemporary Central American writers in the new literary creations being produced in the isthmus - and that Fonseca Mora incorporates in his narrative skillfully - is the use of a metafictional structure in a paradoxical combination of historical facts and fiction. Like Sergio Ramirez, Dante Liano and Horacio Castellanos Moya's narrative, Ramon Fonseca 
Mora's fiction is a literature that highlights the multiple tendencies in the political, historical and esthetic trends in Central America. Authoritarianism, expropriation of land, military abuse and death are some of the themes found in Fonseca Mora's novels and short stories. All of these thematic aspects in Fonseca Mora's narrative signal the writer's obsession for literary historiography. As per the incorporation of historical aspects in Fonseca Mora's fiction, most specifically in his novel El desenterrador the Panamanian critic and literature professor Ricardo Arturo Ríos has stated that:

La historia se hace personaje literario cuando ese acontecer trasciende su localidad y se universaliza. ... Ramón Fonseca Mora, enfrenta con osadía quijotesca, tanto los trágicos sucesos del 9 de enero de 1964 como la violencia institucional promovida por la dictadura militar de Torrijos, Paredes y Noriega. (2012)

As I have discussed above and in the previous chapters, the contemporary Central American narrative is an amalgam of styles and discourses. The present-day literary production in the isthmus is still linked to the testimonial account, to the historical, the political, the mystery and the thriller literature. This creative production is an attempt to recreate the chaotic contemporary times, and at the same time, it is an artistic product that depicts the persistent war against social injustice. The body of literature being produced by present day Central American writers exhibits the multiple characteristics of this postmodern cultural expression. 


\section{IV.3. El desenterrador: An Overview}

El desenterrador is Ramon Fonseca Mora's fifth novel. The novelist makes use of experimental narrative techniques such as dialogic, multiperspectivism, metatextuality and the use of elements of fantasy literature to create a concrete representation of Panama's present and past. In his novel, Fonseca Mora reviews the struggles of a group of young high school students that confronted the Panama Canal Zone authorities in $1964^{38}$ and questions the political actions of the military regime that governed the Central

${ }^{38}$ The Hay-Bunau Varilla Treaty (1903), which ceded control of the Panama Canal Zone to the U.S. "in perpetuity" in exchange for large initial and yearly payments, caused a lot of resentment amongst Panamanians. The Canal Zone was a strip of land between the Pacific Ocean and the Caribbean that became a U.S. territory with its own police, post offices, courts, television and radio stations. In January 1963, U.S. President John F. Kennedy agreed that in the Panama Canal Zone both the U.S. flag and the Panamanian flag should be flown in all non-military sites. However, Kennedy's assassination put a stop to his executive order, for he never got to sign it. Canal Zone Governor Robert J. Fleming, Jr. issued a decree that stated that neither the U.S. or the Panamanian flag would be flown outside Canal Zone schools, police stations, post offices or other civilian locations. Many Canal Zone residents (Zonians) interpreted it as a U.S. renunciation of sovereignty over the Canal Zone.

As a result Zonians began demonstrating their dissatisfaction with the governor's order by placing U.S. flags around the Canal Zone. After the first U.S. flag to be raised at Balboa High School, a public high school in the Canal Zone designated for children of US employees, was taken down by school officials, the students walked out of class, raised another flag, and posted guards to prevent its removal. Many adult Zonians sympathized with the student demonstrators.

As a sign of discontent around 200 students from the Instituto Nacional, a Panamanian high school near the Canal Zone, marched to Balboa High School, carrying their school's Panamanian flag and a sign proclaiming their country's sovereignty over the Canal Zone. Their civic demonstration was planned and informed to the their school principal and the Canal Zone authorities. Their intention was to raise the Panamanian flag on the Balboa High School flagpole where the Americans had raised theirs.

At Balboa High, the Panamanian students were met by Canal Zone police and a crowd of Zonian students and adults. Tension grew strong and after negotiations between the Panamanian students and the police, a small group was allowed to approach the flagpole, while police kept the main group back.

A half-dozen Panamanian students, carrying their flag, approached the flagpole. In response, the Zonians surrounded the flagpole, sang the Star Spangled Banner, and 
American nation in the 1970s and 1980s. ${ }^{39}$ Fonseca Mora in his novel gives voice to those who fell victim to the abusive nature of authoritarian forms of government.

rejected the deal between the police and the Panamanian students. Confrontations broke out, the group of Panamanians was driven back by the Zonian civilians and police and in the commotion Panama's flag was torn. The Panamanians took this as an act of disrespect and desecration for the sovereignty of Panama. A riot broke out and in the hostile confrontation that lasted several hours through the night of January 9, 196428 people were killed and a vast number were injured.

For more information on the topic see Alan McPherson: Yankee No! Anti-Americanism in U.S. Latin-American Relations. Cambridge: University Press, 2003 (pp. 77-116) and William J. Jorden, Panama Odyssey. Austin: University of Texas Press, 1984

${ }^{39}$ Panama enjoyed a very long period of constitutional democracy in the $20^{\text {th }}$ century - from 1903 until 1968 - though it was dominated by an oligarchy with political hegemony. In 1967, elections were held and Arnulfo Arias Madrid of the Natinal Union Party was declared the winner of elections. The election was marked by violence and accusations of fraud. On October 1, 1968, Arias Madrid took office as president of Panama. He promised to govern the country in a spirit of "national union" that would end corruption. On October 11, 1968, the National Guard ousted Arias and initiated the military government that culminated with the United States' invasion in 1989. Arias, who had promised to respect the hierarchy of the National Guard, broke the pact and started a large restructuring of the Guard. To preserve the Guard's interests, Lieutenant Colonel Omar Torrijos Herrera and Major Boris Martínez commanded the first coup of a military force against a civilian government in Panamanian republican history.

The military justified its acts by declaring that Arias Madrid was trying to install a dictatorship, and promised a return to constitutional rule. The military appointed a Provisional Government Junta that would arrange new elections. However, the National Guard became reluctant to abandon power and began calling itself El Gobierno Revolucionario ("The Revolutionary Government").

Omar Torrijos became de facto leader of Panama from 1968 to 1981. He was never officially the president of Panama, but instead held titles including "Maximum Leader of the Panamanian Revolution" and "Supreme Chief of Government." During Omar Torrijos's control, the military regime transformed the political and economic structure of the country. The constitution was changed in 1972. For the reform to the constitution, the military created a new organization, the Assembly of Corregimiento Representatives, which replaced the National Assembly. The new assembly, also known as the Poder Popular ("Power of the People"), was composed of 505 members selected by the military without the participation of political parties, which had been eliminated by the military. The new constitution proclaimed Omar Torrijos the "Maximum Leader of the Panamanian Revolution", and conceded him unlimited power.

The military dictatorship perpetrated the assassination and torture of more than one hundred Panamanians and forced into exile a number of dissidents (see Zárate 15). 
Ricardo Arturo Ríos speaking about the historical events that inspired Fonseca Mora's novel has stated that:

[Fonseca Mora in El desenterrador] [n]arra los trágicos acontecimientos del 9 de Enero de 1964 desde ópticas distintas. La marcha de los estudiantes del "Nido de Águilas" hasta los incidentes con los "zonians" en la Escuela de Balboa es emocionante, nos hace sentir la serenidad, valentía y determinación de una juventud heroica. También nos mete en la piel de esa población colonialista que siente como suyo ese territorio canalero, son dos fuerzas antagónicas que chocan con vehemencia.... (2012)

Ricardo Arturo Ríos in his article praises Fonseca Mora’s boldness for taking these historical accounts as the main axes for his novel. El desenterrador is a very ambitious work of fiction inspired by both the events that took place on January 9, 1964, in the Panama Canal Zone and the abusive practices of Omar Torrijos military government later on in Panama's history. The novel narrates the story of Urbano Calvet, a middle-age painter whose life is marked by the 1964 events and the disappearance and killing of his friend "Menéndez" six years later by the Torrijos regime's death squads. The novel is set in several time periods and contains multiple narrative voices. Urbano Calvet is a heroic figure and survivor of the January 9, 1964 events who witnessed how the Americans who fought to protect the Canal Zone wounded and killed several of his schoolmates and shot him in the leg. The protagonist is also a victim of the violent nature

For more information on the topic see William J. Jorden, Panama Odyssey. Austin: University of Texas Press, 1984 
of the war against social injustice brought about by Torrijos' military regime. These two events in Urbano's life traumatize him and set the tone of his isolated existence. Even though he has a mother, a son and a devoted lover who cares for him, he is not able to establish intimate emotional relationships with them. He also has difficulties relating to others. Because of his obsession with the events in his past, Urbano is incapable of accepting not only the affection of his loved ones, but also recognizing the economic and democratic stability achieved in the Central American nation in recent years. Urbano has lived in a distressed state of mind for nearly 30 years and his mental and emotional condition can easily be observed in the following statements made by the protagonist in the novel:

A quien no se le haya perdido un pariente o amigo jamás podrá comprender lo que siento en este instante. Es un dolor profundo, que penetra el alma y que jamás desaparece. Es constante. Siempre está allí, enquistado en las profundidades del ser, y sale de vez en cuando con toda su furia para liberar emociones y transformar vidas. Si alguien muere, se le llora, se le entierra, y el proceso de luto, de curación, sigue su curso hasta que la herida poco a poco sana. Quedan entonces recuerdos generalmente gratos del individuo, y una resignación ambivalente sobre el hecho de la muerte. La paz entonces regresa. Se sabe dónde está el muerto y se puede visitar y llevar flores a su tumba, si se desea. Pero cuando un familiar o conocido desaparece y no es visto nunca más, el proceso se detiene y en su lugar toma posesión la incertidumbre, el dolor y la falta de resignación. Es una herida abierta, sin cicatrizar, de la que 
siempre brota el pus de la rabia, de la angustia, del tormento. Esto puede durar un mes, un año o más.... (374)

From the quote above, the novelist through the use of a narrative technique based on the use of the testimony account, reconstructs episodes of Panama's historical past. Fonseca Mora is able to combine reality with fiction in his novel by narrating the fictional accounts of a patriotic hero and his incapacity to come to a resolution with the traumas developed by the violent nature of a struggle against social injustice.

IV.4. Elements of the noir narrative tradition in El desenterrador

The actions depicted in the novel include the period between 1964-2001.

Urbano's story can be recreated by the reader from the four different fragments of his life that appear in the novel: 1) 1964 when he was young high school student; 2) 1970 when his friend Menéndez is disappeared by Torrijos' death squads; 3) 2000 when Urbano lives in Paris; 4) 2001 when Urbano finds Menéndez's remains. The novel begins by narrating Urbano's experiences as an art student in Paris in the spring of 2000. He has moved to Paris, from his home in the Island of Taboga in Panama after he accepts a mysterious grant offered to him by an unknown entity at the time when he first began to inquire about the resting place of his disappeared friend Menéndez's remains. At first, he is convinced that the grant came from a government institution as recognition for his talent and heroic deeds, but toward the end of the novel it is unclear who was funding his study abroad. The mystery behind the grant seems to be connected with another mystery in the novel, the actions of a female character that in the novel is only referred as M. 
M's true identity is never revealed and all that is known of her is that she meets Urbano by apparent chance at the École National des Beaux Arts in Paris. As the plot of the novel develops, it is suggested that $\mathrm{M}$ belongs to a mysterious sect that seems to have a clear understanding behind the motives of all of the major events in the history of the world and that seeks to find tangible proof of the main source of life in animals and humans. In order to discover these truths, the sect experiments with cats, dogs and humans. In the attempt to find the life source, an enigmatic character who is presumed to be M's brother, or perhaps M herself, kills a vast number of cats and dogs and several prostitutes by performing surgery like experimentations without any sedatives or anaesthetics. During the entire process before the actual killing, the victims are tide down and fully aware that their lives are about to end. The enigma behind M's character, her brothers and the rest of the members of the sect, the spontaneous and unclear manner by which Urbano is able to travel and support a home in Paris; and the sadistic methods employed in the experimentations with animals and humans are aspects of the novel which relate it to the typical noir narrative genre.

Another aspect of El desenterrador that links it to the noir fiction is the detective like quest to find the remains of Menéndez. Urbano and Menéndez were young men who participated in the civic demonstrations that eventually turned into an armed struggle that occurred on January 9, 1964, in the Canal Zone. Menéndez saved Urbano's life that day and since then they became close friends even though Menéndez was older than Urbano. Menéndez eventually became actively involved in the political operations against Torrijos' military government. He became a young leader of the opposition and because of his role as a youth opposition leader he was seized and disappeared by the military 
death squads. Menéndez had a daughter, Soledad, who once she became an adult did everything in her power to track down her father's remains. In her efforts to find her father's resting place, she meets Urbano. In their determination to bring to light the atrocities committed under the military regime, Urbano and Soledad work together to find Menéndez's remains. With the help of Miguel, another of Menendez and Urbano's friends, Soledad is able to unearth his father's remain from an unmarked grave and give them a proper burial, bringing closure to Soledad's quest and an end to Urbano's existential crisis. At the end of the novel, Urbano's demons stop hunting him and he is able to embrace and reciprocate the love of his mother, son and lover.

IV.5. Postmodern Practices: The (Re)construction of Reality in Fonseca Mora's novel El desenterrador.

In the following sections of my analysis of Fonseca Mora's literary work, I investigate specific aspects of postmodern literary production as presented in his novel $E l$ desenterrador. I intente to demonstrate how the Panamanian writer-like the other three Central American writers whose literary work I have already analysed in the previous sections - invariably blurs elements of fact and fiction in his fabulation of reality. I shall focus my discussion on the way by which Fonseca Mora utilizes multiple discursive forms in his postmodern parody of the noir novel.

\section{IV.5.1. Heteroglossia in El desenterrador}

One of the ways by which El desenterrador displays aspects of postmodern fiction is by the presence of a plurality of discourses within the novel. The concept of 
"discourse" is often misused to refer to the text; however, "discourse" refers rather to the social process in which to insert language production, while the notion of text refers to the actual object and material produced by discourses (Hodge \& Kress 6). The concept of "discourse" in this analysis is used to describe the existence and connection of various "registers of language" (microtext) simple or complex, made literally in the novel (macrotext) thus, creating new relationships of meaning (intratextual and extratextual).

Among the multiple traits of postmodernism that Brian McHale lists in his conceptualization of this artistic mode, one of the most highlighted in Fonseca Mora's novel is the presence of a discursive polyphony that makes evident the juxtaposition of different languages, styles and diverse registers as we shall note in the following sections of my analysis.

\section{IV.5.2. The Historiographic Discourse in El desenterrador}

Ramon Fonseca Mora's narrative, like the narrative of the other three Central American writers whose work I have analyzed in this dissertation, has the tendency to incorporate elements of his country's political history and combine them with fictitious accounts. In the previous section of this chapter, I noted some of those historical accounts, but perhaps the most relevant of them is the actual historical figure that inspired Menéndez character and that of his daughter Soledad. I can safely point out that Menéndez character in El desenterrador was inspired by Heliodoro Portugal as Ricardo Arturo Rios points out: "Ramón Fonseca Mora confronta con valor el caso particular de "Menéndez" (Heliodoro Portugal), en esa muerte hubo violencia, tortura, sadismo y maldad ..." (January 05, 2012). 
Heliodoro Portugal was a political activist of the Left-wing Movimiento de Unidad Revolucionaria lead by Floyd Britton who was he, the main leader of the political movement. Four Government Agents near the Coca Cola café seized Portugal on May 14, 1970. He remained in prison in Los Pumas de Tocumen Quarters for a while where he was tortured and allegedly killed. He was never seen or heard until his remains where exhumed and given to his daughters three decades later after he was disappeared. The identity of Portugal's remains where identified as his after his daughter, Patria—who like the character of Soledad in the novel embarked in a years long quest to find the remains of her father-, and other relatives made an official judicial DNA testing requestbrought to the court by none other than Ramon Fonseca Mora. ${ }^{40}$ In the novel, these actual events and the personal characteristics of Portugal are depicted as follows:

Los tres [Menéndez, Urbano and Miguel] estamos sentados alrededor de una mesa en el Café Coca Cola. Es 1970 han pasado seis años desde que los tres nos encontramos por primera vez en una sala del Hospital Santo Tomás. ...

Menéndez es un hombre de ideas muy diferentes a las de la mayoría de las personas. Es optimista. Cree que la civilización avanza. Considera que estamos cada vez mejor. Que cada uno tiene la responsabilidad de que las cosas no se detengan. Piensa que el mal existe y que a veces se apodera de personas, grupos, países. Entonces, los seres

${ }^{40}$ For more information about who was Heliodoro Portugal and the finding of his remains please see ¿Quién era Heliodoro Portugal? Florencio Gálvez F. 2000 
que sienten la necesidad del bien, de la justicia, deben salir de sus cuevas, espada en mano, y luchar en contra de los demonios que intentan introducirse en el mundo....

... Odia a los militares que se adueñaron del poder en Panamá, y cada vez que tiene la oportunidad les hace saber que los desprecia. Participa en cuanta manifestación, protesta, mitin, movimiento hay en contra del yugo que apresó al país....

De repente la puerta del local se abre con violencia. La silueta de dos hombres se recorta en la claridad que penetra al salón. Avanzan. Uno es alto, blanco. El otro es bajo, grueso, oscuro....

Menéndez se tensa. Mira para todos lados. Se lleva la mano a la boca....

Los uniformados recién llegados recorren con la vista el local. Sus ojos se fijan en nosotros. ...

... Menéndez está de pie. El gordo lo esposa....

La puerta del café se abre y sale Menéndez escoltado con las manos atadas. Mi amigo se vuelve en el último instante y mira exactamente hacia donde yo estoy. Sonríe con esa sonrisa tan suya, inexpugnable, e inclina la frente. Le devuelvo la sonrisa. Lo empujan violentamente dentro de un automóvil pequeño, color rojo, que parte con rapidez. 
En ese instante una sensación extraña emerge, surge, nace dentro de mí y me produce angustia. Me hace sentir tristeza, desesperanza. No se apartará de mi jamás. (220-28)

Linda Hutcheon coined the term "historiographic metafiction" to describe those literary texts that emphasize an interpretation of the past but are also deeply selfreflexive-i.e., critical of their own version of the truth as being partial, biased, incomplete, etc. (1988 122-123). According to the Canadian critic, this is the most representative element of postmodernism. The postmodern literary works bear the false impression that they enjoy fictional and linguistic autonomy in reflecting upon themselves and upon their own course of creation and reception, an illusion that the text itself finally dismisses. In addition, the inclusion of historical characters and situations in the fictional setting points toward the weakening of the pretenses of objectivity and empiricism of historiography as claimed by most traditional views of history writing. In this study of Ramon Fonseca Mora's El desenterrador, I did not find any narrative evidence that points towards the text being a self reflexive text, but I did find several examples within the novel that indicate an emphasizes on the interpretation of the historical past as I have noted above. Thus, Fonseca Mora resorts to the [re]invention of historical facts and characters in the course of his fictional narrative and composes "historiographical" fiction based upon the experiences lived in Panama in January of 1964 and during the military regime of the 1970s and 1980s.

History has two versions: the official found in textbooks, and the versions found in the literary creations as readers can do in novels and short stories. Some might argue that the latter is not reliable, that it is the opinion of the author, but many historical events 
would not have been known without their incorporation into the literary space. As I have noted throughout this dissertation, contemporary Central American writers like Ramon Fonseca Mora exhibit an obsession for [re]interpreting, [re]creating, historical accounts of the armed struggles and the fight against social injustice witnessed in the region during the last four decades of the $20^{\text {th }}$ century. By doing so, these writers recreate the feeling of skepticism and lack of coherence certainty in the official discourse of history provided by the governing institutions of these countries. These writers accomplish this task by presenting a new perspective in which historical facts and fictions are combined into a new form of literature that I denote as the new postmodern noir inspired narrative of Central America.

\section{IV.5.3. A Parody of the Testimonial Account in El desenterrador}

I have argued in this dissertation that contemporary Central American writers show a concern for history in their literary creation. I have also pointed out that these writers have broken away from the narrative tradition established by the so-called "Boom" period of the 1960s and that through the use of a series of literary technics such as parody, multiperspectivism, and metatextuality, the new generations of writers from the isthmus have demonstrated a shift in the literary discourse of the region. The new modality in the Central American letters of contemporary times shows significant formal, verbal, thematic and discursive changes. Perhaps one of the most noteworthy changes in the literary new productions is the incorporation of parody. In my analysis of Fonseca Mora's El desenterrador, I find that the author makes a parody of several literary genres, and three of these genres are the testimonial, the detective fiction and fantasy literature- 
I have noted how the novel being analysed in this chapter incorporates elements of the detective and fantasy genre in Section IV.4. Fonseca Mora blends all of these narrative styles in order to recreate the environment in which military abuse and social injustice are at the center stage and by doing so the novelist denounces the violence and cruelty experienced by many in Panama during the 1960s and 1970s.

Traces of the testimonial narrative can be noted in the novel by a very specific writing technique utilized by the novelist, the narration in the first person of a fictional character that recounts historical events as if he was a real life participant. Urbano Calvet narrates his life experiences through the novel in the first person and in an oral stylevery much like the one used in testimonial narrative of the previous literary period in Central American letters. The narrative style employed by the novelist is a direct reference to the testimonial genre. As I noted earlier in chapter two of this work, the testimonial discourse was privileged in the narrative produced in the isthmus especially when it dealt with the relationship between history/reconstruction of memory to signal in the literary realm the human rights abuses and the violence and oppressions of the wars against the political regimes that was the experience in many of the Central American nations. However, in Fonseca Mora's novel the reference to the testimonial account serves as a postmodern parody that allows a panoramic view of the events that took place on January 9, 1964 in Panama's Canal Zone and the state of affairs during the military regime of Omar Torrijos in the 1970s in Panama.

The use of a narrative technique inherited from the testimonial account in $E l$ desenterrador can be seen in the following fragment of the novel. Urbano narrates his sentiments of patriotism as he reminisces about his participation in the incidents that 
occurred in 1964 and while taking part in the official celebration of the return of the Canal Zone from the United States jurisdiction to Panamanian authorities on December $31^{\text {st }}, 1999:$

Colmados de alegría y entusiasmo doblamos hacia la izquierda y nos dirigimos a la Avenida Gorgas. La multitud cantaba a grandes voces una canción de amor a Panamá. Las notas de la melodía lo envolvían todo. ¡Qué diferencia a lo acontecido tantos años atrás en aquel pedazo de patria cuando nuestro grupo diminuto se apretaba los unos a los otros, con temor, tratando de pasar lo más lejos posible de los policías zonians que nos amenazaban!

De pronto un sentimiento profundo de orgullo se apoderó de mí. De los que tenía a mi alrededor, estaba seguro de que eran muy pocos los que habían caminado aquel viacrucis años atrás por esa misma calle. Yo era uno de los pocos privilegiados que podía aun recordar aquella experiencia. Nadie de los que me rodeaba sabía aquello que me distinguía, es cierto - caminaba solo, sumergido en mis recuerdos- Lo esencial para mí era que sabía lo que había hecho, y que no era necesario que nadie más estuviese enterado. Había hombres y mujeres en aquella marcha de júbilo por el retorno del Canal, con suficiente edad para habernos apoyado en nuestra lucha en 1964, pero reconocí muy pocos.... $(131-32)$

Fonseca Mora's protagonist/narrator, unlike the narrators of testimonial accounts, is a work of fiction and not a real individual telling his own experiences in times of social 
tension. As an artistic creation, this character represents the author's will to speak and behave in whichever way the novelist desires him to do so. Fonseca Mora's narrator, unlike the writer of a testimonial account who accounts for factual eyewitness events in the testimonial narrative, is a creative invention that serves the novelists intention to [re]interpret the historical past as can be seen in the fragment from the novel above. By doing so, the writer recreates the feeling of skepticism and lack of coherence certainty in the official discourse of history provided by the governing institutions of his country. Fonseca Mora through the use of a parody inspired by the narrative style inherited from the testimonial account presents a perspective in which historical facts and fictions are combined into a new form of literature that we can denote as the new postmodern Central American narrative.

\section{IV.5.4. The Socio-Cultural and Political Discourse in El desenterrador}

In addition to creating a parody of the testimonial account in order to launch himself and the reader into a re-invention of his country's recent history through the reading of his novel, Fonseca Mora also incorporates a socio-cultural discourse in his novel. The socio-cultural discourse in the novel is made evident by the incorporation within the novel of themes that show the rise of urban popular culture, the emergence of consumer society and the influence of mass media and the advent of the new era of cyber space. These thematic elements within Fonseca Mora's novel are made obvious by the commentaries made by the characters of the novel. The novel shows the new cultural and social changes undergone by Panamanian society during the last decade of the $20^{\text {th }}$ century. These social and cultural changes can be observed in the novel by the 
contrasting the ideology, interests and aspirations of the main character, Urbano, to those of his son, Jorge.

As I have stated before, Urbano is a very lonely individual whose memories of the violent episodes that he lived as a young man have caused him to isolate himself from the rest of the world. Urbano's character is full of doubts and rejection for what is different and new. The fact that he lives in an island away from the contemporary life of the city of Panama, his constant quarrels with his only son, his lack of communication with his mother and his inability to recognize the love of Anabella, his lover, account for his selfimposed seclusion brought about by his fixation on the traumatic events he experienced and by the violence of political oppression and social injustice. Jorge describes his relationship with his father in the following manner:

Mi padre vive en otra época. ¡Está totalmente desfasado! Por ello no nos podemos comprender. No peleamos ya, es cierto, pero tampoco existe ninguna comunicación entre nosotros. ¿ De qué podríamos hablar si él todavía vive en otro tiempo, en otro lugar? Su interés está en un Panamá que ya no existe. Sus luchas son con fantasmas que han partido de la esfera terrenal hace muchos años, y de los que pocos hoy se acuerdan. Yo, por mi parte, estoy clavado en el presente y sueño con el futuro. Amo mi profesión en el negocio de la banca privada y mis conversaciones giran en torno a temas que considero apasionantes, tales como la internet o los viajes a la luna y a las estrellas. También-lo digo con orgullo — mi interés principal en la vida es hacer dinero para vivir 
mejor y para sentir que he triunfado en la sociedad que me ha tocado vivir (168).

Further down in the same section of the novel, Jorge describes Urbano's fixation in the past as the reason for their lack of communication:

... En su época cuando papá era joven, no había televisión y los teléfonos eran grandes, pesados, con números de cinco dígitos para marcar. ... ¡Qué atraso! Por eso mi padre es como es. Creció en otro país. Con los gringos a nuestro lado. Eso todavía no lo perdona. Pero ya se fueron. Nos dejaron tranquilos, y el pobre viejo todavía cree que están aquí y que sus amigotes lo van a llamar en cualquier momento para salir a protestar y tirar piedras. ¡Estrés postraumático! Eso es lo que debe ser. Es difícil mantener una conversación con él sin que desemboque en alguna de sus obsesiones. Comenzamos a hablar de mi trabajo, de mis planes, objetivos, o simplemente menciono la lluvia o el mar embravecido que tuve que enfrentar en la travesía a Taboga, e irremediablemente terminamos hablando del 9 de Enero, de la lucha de Panamá por el Canal, de la dictadura, de su compañeros desaparecidos o muertos, temas que son de poco o nulo interés para mí (169).

Besides portraying Urbano's obsession for the past, the segments above show the generational gap that exist between father and son. This generational gap makes it even harder for father and son to communicate because of Urbano's resistance to the socioeconomic progress of the Panama of the last decade of the 20th century. Urbano's view 
of the contemporary times as expected is contradictory to that of his son and can be noted in the following lines from the novel:

¡Qué angustia más hijueputa la que siento en este momento! Hasta mi propio hijo piensa que estoy medio desquiciado por ponerme a hurgar en mi pasado. Y si ahora me dedico a escarbar tratando de encontrar tumbas viejas, de hace más de treinta años, va a considerar que estoy listo para ser ingresado en un manicomio. ¿Qué les pasa a los jóvenes de hoy? ¿Dónde están sus anhelos de un mundo mejor? ¿Dónde se encuentra escondido el idealismo que nos hacía soñar y tirarles piedras a los enemigos de una vida justa? Ahora todo es dinero, bienestar material, apariencia personal. La juventud trabaja duro pero para comprar mejores atuendos, autos más lujosos, casas más grandes. ¿Para eso se sacrificó nuestra generación? (308)

The socio-cultural discourse in El desenterrador is perhaps best exemplified by the irrefutable generational gap between Urbano and Jorge. They both have different ideas about the world they live in. Whereas Urbano still believes in fighting for social equality for all mankind and for the eradication of social injustice — as it was perpetuated by the youth of his generation in many parts of the world-, his son Jorge exhibits the contemporary yearning to have access to monetary means in order to satisfy personal desires. Jorge's comments and actions represent the neoliberal ideals and its free market economic system that had always existed in Panama since the days of the Spanish Colony. Panama as a merchant enclave was a reality from the middle of the 19th century and it never experienced the long period of civil wars that characterized the region in the 
$20^{\text {th }}$ century, despite the fact that it was part of the 19th century civil wars when it was part of Colombia. Jorge's lack of ideals for a better tomorrow for all humankind clashes with the utopian visions of his father. Urbano's ideals are those that prevailed during the revolutionary years of the 1960s, 1970's and 1980's in the Central American region and were imported into Panama and adopted by the opponents of the Torrijos and Noriega military regimes and were used to oppose these regimes. Jorge represents the new generation of the ever-prosperous Panama after the control of the Canal by Panama and the boom that has influenced the nation during the past years.

\section{IV.5.5. Other Postmodern Structural Aspects of El desenterrador}

In the previous sections of this chapter, I concentrated my argument on the literary technical resources utilized by Fonseca Mora in order to conceive a mixture of fact and fiction, how he is able to create fictional characters whose lives are linked to real individual and their participation in historical accounts. I also discussed how Fonseca Mora employs multiple discourses within the novel that portray Panama's present day reality and that of the past. In this section, I will focus the discussion on specific structural mechanisms present in the novel that indicate its close connection to postmodernist fiction writing. Brian McHale's theories of postmodern fiction maintain that postmodernist texts utilize the actual book for their own benefit. His argument is based on the idea that the structure of the literary work rests on the physical book and its typography. The use of titles, headings, concrete prose, photographs, illustrations, texts in multiple columns, and the non-chronological enumerations of chapters conform what McHale calls the "schizoid text" in which visual and verbal discourses cross each other in 
polyphonic attitude (1987 164). El desenterrador seems to show very little evidence of this sort of highly experimental postmodern typography narrative. However, the novelist has produced a novel that breaks away from the traditional narrative model. Even though the novel consist of three parts - each separated by Roman numerals — and an epilogue, these segments of the novel do not signal the traditional organization of a work of fiction (introduction, body and conclusion). Each of the three main parts of the novel includes sub-segments that are not headed by either a title or a number. These subdivisions, at times, are narrations of the same events described by multiple characters of the novel. These narrated events do not follow a lineal pattern in the plot development and they are not arranged in any specific manner. Some of these fragments also correspond to newspaper notes that help maintain the mystery behind the puzzle of the unethical experimentations with animals and humans by some individuals who are in the search of tangible proof of the main source of life in living creatures.

Fonseca Mora makes an attempt to present his reader with an innovative way of fictional narrative through the use of a ludic experimentation in his narrative that is very much linked to the postmodern deconstructive game. The novelist constructs his text using a collage of narrative discourses, narrative genres and multiple perspectives. $E l$ desenterrador incorporates not only a heteroglossia in which the socio-political and the historical discourses are the most accentuated or a mixture of several narrative traditions such as the testimonial, the noir and the fantasy narrative. The novel, as mentioned above, also incorporates multiple points of view narrated by numerous narrative voices whose accounts jump back and forward throughout the novel, thus breaking away from the lineal model of the classic novel. In the novel, these multiple narrative voices create a 
"polyphony" through which the main character, Urbano, and almost the entire repertoire of characters in the novel are able to express the fears, hopes and desires that contemporary times inspire in them. Ricardo Arturo Ríos when speaking about the narrative style employed by Ramon Fonseca Mora in El desenterrador has stated that:

La estructura multipolar con definidos conjuntos narrativos, atrapa al lector, lo agobia con una carga emocional que lo hace sufrir, llorar, reír, rechazar, identificarse, amar y odiar todo lo que ocurre. Fonseca Mora es hábil al entrecruzar, con creciente suspenso y con el uso de los tiempos simultáneos todas las pasiones humanas. Siempre hay un contrapunto, matices de un modo de ser pleno de ambigüedades como de metas definidas. Eso hace que esta novela sea diferente e interesante, ya que es un coro polifónico con múltiples voces narrativas, así Bill, Soledad, Jorge, Anabella, Miguel y sobre todo Urbano expresan sus ambivalencias, temores y sentimientos. Ellos rompen la típica monotonía y secuencia lineal de otras narraciones que nos abruman con su inmovilismo literario. (2012)

Thus, with the use of these experimental techniques, Ramon Fonseca Mora produces postmodern literature in which the perception of reality does not always follows a logical order, but does seem to match the rational world for the most part.

\section{6. Conclusion}

Central American literature, traditionally, has been characterized by the incorporation of cultural idiosyncrasy, patriotism and the portrayal of the natural 
landscape. The literature of the region has also shown a tendency to incorporate the fight against social injustice as one of its fundamental themes. Ramon Fonseca Mora's fifth novel, El desenterrador, exhibits all of these characteristics as seen in the following comments made by Urbano Calvet, Fonseca Mora’s protagonist: “Aun con su carácter de ciudad de paso, de oportunidades, nuestra identidad nacional está bien definida, quizás por la necesidad que hemos tenido a través de los siglos de defenderla de los ataques de los que solo procuran utilizarla para su beneficio personal" (250). The sentiments of patriotism and of cultural idiosyncrasy that prevail through El desenterrador are combined with a series of experimental writing techniques that exhibit the novelist tendencies for postmodern fiction writing. The novel is a very ambitious work of fiction with many of the components of what constitutes postmodern narrative. Through the combination of styles and discourses like the testimonial account, the historical, the political, the mystery and the noir; and through the use of experimental writing techniques such as dialogism and multiperspectivism Fonseca Mora in his novel creates a certain representation of the events that took place on January 9, 1964 in the Panama Canal Zone and the abusive practices of Omar Torrijos military government. 


\section{CONCLUSION}

The four Central American writers whose works I have studied in this dissertation were born between the late 1940s and the early 1950s. They belong to a generation that witnessed the disappointment and horror of the violence of civil wars and military regimes lived throughout Central America in the last four decades of the $20^{\text {th }}$ century. The explanation of this dark side of the war against social injustice has been a constant theme in their literary projects. El cielo llora por mí, by Nicaraguan writer Sergio Ramírez; El hombre de Monserrat, by Guatemalan writer Dante Liano; El arma en el hombre and La diabla en el espejo, by Salvadoran writer Horacio Castellanos Moya; and El desenterrador, by Panamanian writer Ramon Fonseca Mora, are highly structured novels where violence and the sense of despair - inherited from the noir narrative tradition-looms in the background. Events that at first glance might be considered casual or trivial help the writers recreate what seem to be real life moments that reflect the tragic years of the armed struggle and those immediately following the revolutionary years when a sense of disillusionment with the failed revolutionary projects emerged in these war-affected countries.

Other aspects of the noir literary tradition inherited by the five novels I have studied in this dissertation are the constant struggle between good and evil and the use of direct and everyday/colloquial language. The precision by which events are documented in the novels reminds the reader of the testimonial narratives, which were dominant in Central America during the 1970s and 1980s. These novels feature a range of characters that reflect the challenges imposed by a post-war society with its neo-liberal governments and their free- 
market economic system. Many of these characters belong to an emerging middle class that mirrors a group of individuals who do not have a social conscience and whose only care is how to have access to easy money and satisfy their individual desires and passions. These characters contrast with another group of individuals, those who in the novels actively participated (and still partake) in the fight against social injustice and criminality. These are individuals who represent real life revolutionary heroes who continue dreaming of a better world for the citizens of Central America. Through the use of multiple characteristics of both the noir narrative tradition and the postmodern cultural expression the four novelists—-whose work I have studied in this dissertation—-depict the events that shaped the modern history of the countries from which they emerge. The revolutionary armed struggle, the state of terror imposed by military regimes and the fight against drug trafficking and organized crime are among the major themes of these contemporary works of fiction, which I have categorized as perfect examples of the Post-revolutionary Postmodernism Central American Detective Fiction at the turn of the 21st Century.

The novels analyzed in this dissertation display the two main impulses that, according to Ihab Hassan, constitute a postmodern work of art: the will to (self)dissolution, and the challenge of institutionalized high arts. These novels exhibit the ambiguity proposed by multiple narrative points of view that diffuse and disseminate the basic assumptions of realism. The employment of a series of technical narrative elements such as dialogism, multiperspectivism, metatextuality, parody, and in some cases the fantastic — as we noted in the discussion of Ramon Fonseca Mora's novel — to portray the crime, corruption and social injustice that prevails in post-war/post-military Central 
America, demonstrate a celebration of plurality that contradicts the hegemonic cultural systems.

The novels studied in this dissertation also exhibit features of Brian McHale's concept of postmodernist fiction. According to McHale, while modernist texts are organized around a fixed perspective, either of a character or of a detached narrator, postmodern literary works can be composed by a "heterotopic" space that can be simultaneously constructed and deconstructed by multiple devices, such as “juxtaposition, interpolation, superimposition, and misattribution." Through the use of these strategies postmodernist writers can set up the ontological limitations of the fictional world; limitations that can easily be simultaneously established and transgressed. McHale also focus his attention on the use of plurality of discourses that is present in a postmodern work of fiction. This heteroglossia or discursive hybridity, manifested by the juxtaposition of languages, styles and multiple points of views, can be achieved by discursive polyphony through the use of a dialogical confrontation between the anti-language of the subcultures and the official language of a particular society.

The five novels under analysis in this dissertation reveal these characteristics of postmodernism by the use of multipolar narrative structures and streams of consciousness that seek to portray the points of view of multiple key characters in the novels. Through the use of these postmodernist narrative techniques the four Central American writers that I have studied capture the readers' attention and make them experience a large spectrum of emotions. As readers confront the events depicted in these texts, they share the experience of their characters and empathize with their tragic condition. In my analysis of Sergio Ramirez's El cielo llora por mí; Dante Liano's El hombre de Montserrat; 
Horacio Castellanos Moya's La diabla en el Espejo and El arma en el hombre; and in Ramon Fonseca Mora's El desenterrador, I noted how the use of dialogism, multiperspectivism and metatextuality help the writers recreate the events that marked the socio-cultural reality of Central America in the last four decades of the $20^{\text {th }}$ Century In A Poetics of Postmodernism (1988) Linda Hutchon's discussion of postmodernism focuses on the increasing problematization of history in contemporary fiction. In her book, Hutcheon highlights aspects of theory and practice that lead to a concept of postmodernism that could incorporate both postmodern culture and our discourses about it. The objective of her poetics is to understand the paradoxes that result from the confrontation of the self-reflexive forms of modernism and the new interest for the historical, the social and the political elements that characterize postmodern artistic productions.

As I noted before, the Central American novelists whose work I studied in this dissertation produce postmodern fiction by amalgamating historical facts and fictional invention within narratives that incorporate the noir sensibility. In their novels, Sergio Ramirez, Dante Liano, Horacio Castellanos Moya and Ramon Fonseca Mora integrate elements of the noir tradition, such as the suspense and the mystery surrounding the death of key characters, as well as by setting the action in violent environments. In doing so, the four Central American writers, exhibit what Todorov has determined as an essential aspect of the noir narrative when he states that: "La novela policial de la serie negra funde ambas historias en una sola, subordinando el element del misterio (la curiosidad o búsqueda de respuestas) al suspense (expectación) proporcionado por la acción, en un clima de violencia desatada" (Colmeiro 44). Having made the comments above the 
reader must never assume that El cielo llora por mí, El hombre de Montserrat, La diabla en el espejo, El arma en el hombre and El desenterrador are typical noir novels inspired by the American tradition of the genre. The informed reader will immediately note that in these novels the authors take the main features of the noir detective novel and then reshape them into a postmodern parody of the genre, thus, exhibiting another aspect of postmodern fiction writing: the parody of early forms of artistic productions.

The incorporation of fictional characters, whose biographical backgrounds depict the reality lived during the times of political turmoil and armed struggles in the Central American region, also demonstrate how these four novelists' works display features of postmodern narrative. The majority of their fictional characters seem to be versions of individuals who were involved, some way or another, in the political armed struggles lived in the isthmus in the last decades of the $20^{\text {th }}$ century and whose experiences serve these authors as vehicles to construct new perspectives of historical accounts while questioning the official discourse of present-day governments. Following Linda Hutcheon's concept of "historiographic metafiction" and Ihab Hassan's notions of "selfdissolution," "immanence" - the capacity of the mind to diffuse and disseminate itselfand "the will to unmake," I can conclude that the four Central American writers resort to the [re]invention of historical facts and characters in the course of their fictional narrative and compose "historiographical" fiction based upon factual events. By reinventing history in this way, these novelists challenge traditional notions of mimesis and pose questions that are in tune with the historical skepticism of postmodernist fiction, while criticizing the current state of affairs in Central American nations. 
The above-mentioned elements of postmodern fiction writing are made evident in the works under discussion by the use of experimental writing techniques in the reconstruction of experiences lived by real life individuals who were involved or suffered the hardships of the political armed struggle that took place throughout the Central American isthmus during the last four decades of the $20^{\text {th }}$ century. Thus, I can conclude that these writers in their narrative work create "historiographic metafiction" through the process of diffusion and dissemination of the collective experience of politically committed historical figures in the reconstruction of the biographical past of their characters. By doing so, the novelists echo the feeling of skepticism and lack of coherent reality that characterizes postmodern culture. Sergio Ramírez, Dante Liano, Horacio Castellanos Moya and Ramón Fonseca Mora build up a new narrative paradigm in which the boundaries of history and fiction are blurred and thus create a new form of literary narrative, which I can describe as the post-revolutionary post-modernism Central American detective fiction at the turn of the 21 st century. 


\section{BIBLIOGRAPHY}

Acevedo, Ramón Luis. La novella centroamericana. San Juan: Editorial Universitaria, 1982.

Acosta, Leonardo. Novela policial y medios masivos. Havana: Editorial Letras Cubanas, 1989.

Aínsa, Fernando. "La reescritura de la histoira en la nueva narrativa lationamericana." Cuadernos Americanos. 5.4 (1991): 13-31. Print.

---. "Nueva novela histórica y relativización del saber historiográfico." Casa de las Américas. 202 (1996): 9-18. Print.

Arias, Arturo. Gestos ceremonials. Narrativa centroamericana, 1960-1990. Ciudad de Guatemala: Artemis and Edinter, 1998.

Asencio Ibáñez, María Annabely. "Ironía, humorismo y denuncia social en El misterio de San Andrés y El origen y la finalidad de Dante Liano. Thesis. Universidad de San Carlos, 2005. Print.

Aznarez, Juan Jesus. "Nicaragua celebra el desafuero por robo del ex presidente Aleman.” El País. 21 September 2002. On-line.

Baqueros Goyanes, Mariano. Estructuras de la Novella Actual. Madrid: Castalia, 1989.

Beverly, John. "The Margin at the Center: On Testimonio (Testimonial Narrative)." Modern Fiction Studies. 35.1 (1989): 11-228. Print.

Beverly, John and Oviedo, Jose. "The Postmodern Debate in Latin America." Boundary 2. $20.3(1993)$

Beverley, John and Zimmerman, Marc. Literature and Politics in the Central American Revolutions. Austin: University of Texas Press, 1990.

Boileau-Narcejac. La novella criminal. Barcelona: Tursquets, 1980.

Calinescu, Matei. Five Faces of Modernity. Durham: Duke University Press, 1987.

Carranza, Vilmar Rojas. "La imagen mediática en La diabla en el espejo: entre el poder y la exclusion.” Inter Sedes 4.6 (2003): 147-159. Print.

Castellanos Moya, Horacio. Baile con serpientes. San Salvador: Ministerio de Educación, 1996. 
---. Donde no estén ustedes. Mexico, D.F.: Tusquets, 2003.

---. Insensatez, Mexico, D.F.: Tusquets, 2004.

---. La diabla en el espejo. Madrid: Ediciones Linteo, 2000.

---. El arma en el hombre. Mexico, D.F.: Tusquets, 2001

---. El asco. Thomas Bernhard en San Salvador. San Salvador: Editorial Arcoiris, 1997.

---. Recuento de incertidumbres: Cultura y transicion en El Salvador. San Salvador: Ediciones Tendencias, 1993.

Cawelti, John. Adventure, Mystery, and Romance: Formula Stories as Art and Popular Culture. Chicago: University of Chicago P., 1976.

Critchfield, Richard. An American Looks at Britain. New York: Doubleday, 1990.

Coello Gutiérrez, Emilinao. "Variantes del género negro en la novella centroamericana actual (1994-2006)." Istmo. Revista virtual de estudios literarios y culturales centroamericanos. 17 (2008) http://collaborations.denison.edu/istmo/n17/proyectos/coello.html

Colas, Santiago. Postmodernism in Latin America: The Argentinian Paradigm. Durham and London: Duke UP, 1994.

Colmeiro, F. Jose. La Novela Policiaca Española: Teoría e Historia. Barcelona: Editorial Anthropos, 1994.

Cortez, Beatriz. "Estética del cinismo: La ficción centroamericana de posguerra." Ancora: Suplemento Cultural de La Nación. San José Costa Rica. 11 Mar. 2001 http://www.nacion.com/ancora.2001/marzo/11/historia3.html

Cuddon, J. A. Dictionary of Literary Terms and Literary Theory. Harmondworth: Penguin, 1991.

Dällenbach, Lucien. The Mirror in the Text. Trad. Jeremy Whiteley and Emma Hughes. Chicago: Univeristy of Cicago P., 1989.

---. "Reflexivity and Reading." New Literary History. 11.3 (1980): 435-249. Print.

Delgado Aburto, Leonel. Márgenes recorridos. Apuntes sobre procesos culturales y literature nicaraguense del siglo XX. Managua: Instituto de Historia de Nicaragua y Centroamérica, 2002. 
De Toro, Alfonso. "Postmodernidad y latinoamérica (con un modelo para la narrative postmoderna)." Iberoamerica. 155-156 (1991): 441-467. Print.

D'haen, Theo. "Popular Genre Conventions in Postmodern Fiction: The Case of Western" Exploring Postmodernism. Ed. Calinescu and Fokkema. Amsterdam and Philadelphia: Benjamins, 1990.

Diaz, Cesar. La Novela Policiaca. Barcelona. Ediciones Acervo, 1973.

Díez Borque, José. Literatura y cultura de masas: Estudio de la novela subliteraria, Madrid: Alborak, 1972.

Eloy Martínez, Tomás. El cantor de tango. Buenos Aires: Planeta, 2004.

Fernández Colmeiro, José. “Desde el Balneario.” Quimera. 73 (1988). Print.

Figueroa Ibarra, Carlos. El recurso del miedo, ensayo sobre el estado y el terror en Guatemala. San José: Editorial EDUCA, 1991.

Fonseca Mora, Ramón. La danza de las mariposas. Panama: Editorial Portobelo, 1995

---. El desenterrador. Panama: Grupo Santillana de Ediciones/Alfaguara, 2007.

---. Ojitos de Angel. Panama: Grupo Santillana de Ediciones/Alfaguara, 1997.

Franco, Jean. "The Nation as Imagined Community." The New Historicism. Ed. H. Aram Veeser. New York and London: Routledge, 1989. 204-12.

Fuentes Montenegro, Luis. "La narrativa de Fonseca Mora.” El siglo. 18 August 2009. Print.

Gálvez, Florencio F. ¿Quién era Heliodoro Portugal? Crítica (2000) http://www.critica.com.pa

Gamez, José Dolores. Historia de Nicaragua. Vol. I and II. Managua: Fondo de Promoción Cultural-BANIC, 1993.

García Canclini, Nestor. Culturas hibridas estrategias para entrar y salir de la modernidad. Mexico: Grijalbo, 1989.

Grinberg Pla, Valeria. "La nueva novela histórica de finales del siglo y las nuevas corrientes historiográficas." Istmo, Revista virtual de estudios literarios y culturales centroamericanos. 2 (2001) http://www.wooster.edu/istmo/ 
Gonzalez-Ortega. "La novela latinoamericana de fines del siglo XX: 1967-199. Hacia una tipología de sus discursos.” Moderna Sprak. 93.2 (1999): 203-228. Print

Guatemala, Memoria del Silencio, Resumen del Informe de la Comisión para el Esclarecimiento Histórico. Impresión Aldea Global, S.A/Diarios Modernos, S.A. 1999.

Guatemala Nunca Mas. Oficina de Derechos Humanos del Arzobispado de Guatemala, Informe Proyecto Interdiocesano de Recuperación de la Memoria Histórica. Edición Gratuita, Versión Resumida. Diario Siglo Veintiuno. 6 June 1998.

Handy, Jim. Gift of the Devil: A History of Guatemala. Cambridge: South End Press, 1984.

Hassan, Ihad. The Dismemberment of Orpheus: Towards a Postmodern Literature. Madison: U of Wisconsin P, 1982

---. The Postmodern Turn: Essays in Postmodern Theory and Culture. Columbus: Ohio State Press, 1987.

Henriquez, Estela, et. al. " Diputados disidentes se separan de ARENA.” La Prensa Gráfica. 23 October 2009. www.laprensagrafica.com

Hilfer, Anthony. The Crime Novel: A Deviant Genre. Auistin: University of Texas P., 1990

Hodge, Robert. Literature as Discourse. Baltimore: The Johns Hopkins UP, 1990

Hodge, Robert and Kress Gunther. Social semiotics. Ithaca: Cornell UP, 1988.

Holquist, Michael. Whodunit and Other Questions: Metaphysical Detective Stories in Post War Fiction. New York: Most and Stowe, 1971.

Hutcheon, Linda. A Poetics of Postmodernism: History, Theory, Fiction. New York and London: Routledge, 1988.

---. Narcissistic Narrative: The Metafictional Paradox. New York and London: Methuen, 1984.

---. The Politics of Postmodernism. New York and London: Routledge, 1989.

Huyssen, Anderas. After the Great Divide. Bloomington and Indianapolis: Indiana University Press, 1986.

Jameson, Fredric. "Postmodernism and Consumer Society." Postmodern Cluture. Ed. 
Hal Foster. London and Sydney: Pluto Press, 1985.

Jorden, William J. Panama Odyssey. Austin: University of Texas P. 1984.

Juan-Navarro, Santiago. La metaficción historiográfica. Valencia: Ediciones Episteme, S.L., 1998.

---. Re-contextualizing Historiographic Metaficiton in the Americas: The Examples of Carlos Fuentes, Ishmael Reed, Julio Cortazar, and E.L. Doctorrow. Diss. Columbia University, 1995. Print.

Kinloch Tijerino, Frances. Nicaragua en busca de su Identidad. Managua: Instituto de Historia de Nicaragua, Universidad Centroamericana, 1995.

Kokiotovic Misha. "Neoliberal Noir: Contemporary Central American Crime Fiction as Social Criticism." Clues. 24.3 (2006): 15-29. Print.

Kozak Rovero, Gisela. "Castigo divino, de Sergio Ramírez: novella policial, folletinesca, satírica y autorreflexiva." Iberoamerica. 2.1 (2001): 27-41. Print.

LaCapra, Dominick. History \& Criticism. Ithaca and London: Cornel UP, 1985.

Leyva, Hector M. "Narrativa de los procesos revolucionarios centroamericanos 19601990.” Diss. Universidad Complutense de Madrid, 1995. Print.

Liano, Dante. La crítica literaria. Guatemala: Editorial Universitaria Guatemalteca, 1980.

---. El Hombre de Montserrat. Mexico D.F.: Editorial Aldus, 1994.

---. El lugar de su quietud. Guatemala: Editorial Cultura, 1989.

---. El misterio de San Andrés. México D.F.: Editorial Praxis, 1996.

---. Visión y Crítica de la Literatura Guatemalteca. Guatemala: Universidad de San Carlos, 1997.

Lord, Geoffrey. Postmodernism and Notions of National Difference: A Comparison of Postmodern Fiction in Britain and America. Amsterdam and Atlanta, GA: Rodopi, 1996.

Lopez, Vladimir. "Nicaragua y el Istmo, paraíso de mafiosos.” El Nuevo Diario. 30 May, 2011. Print.

Luciak, Ilja A. Despúes de la revolucion: igualdad de género y democracia en El 
Salvador, Nicaragau y Guatemala. San Salvador: UCA Editores, 2001.

Lyotard, Jean-Francois. The Postmodern Condition: A Report on Knowledge. Trans. Geofff Bennington and Brian Massumi. Minneapolis: University of Minnesota Press, 1979.

Mackenbach, Werner. "Entre política, historia y ficción. Tendencias en la narrativa centroamericana a finales del siglo XX." Istmo, Revista virtual de estudios literarios y culturales centroamericanos. (2007). Online http://collaborations.denison.edu/istmo/articulos/mackenbach.html

---. Intersecciones y transgresiones: propuestas para una historiografía literaria en Centroamérica. Hacia una historia de las literaturas centroamericanas. Ciudad de Guatemala: F\&G Editores, 2008.

---. "La nueva novella histórica en Nicaragua y Centroamérica." Istmo, Revista virtual de estudios literarios y culturales centroamericanos. 1 (2001). http://www.wooster.edu/istmo/

Mackenbach, Werner and Ortiz Wallner, Alexandra. "(De)formaciones: violencia y narrative en Centroamérica." Iberoamericana 8.32 (2008): 81-97. Print.

McPherson, Alan. Yankee No! Anti-Americanism in U.S. Latin-American Relations. Cambridge: University P., 2003.

Maldonado, C.S. "Ortega abre la puerta a su reelección al liberar a Alemán.” El País. 17 January 2009. Print.

Marenco Eduardo. "Secuestro de la aeronave envuelto en nube de temores y misterios." La Prensa 6 August 2001. Print.

Mallin, Jay. "Salvador-Honduras War, 1969.” University Review (2004). http://www.airpower.maxwell.af.mil/airchronicles/aureview toc/AUReview1970/ $\underline{\text { AUReview1970Mar-Apr.htm }}$

Maristain, Mónica. "En el Salvador todavía hay heridas muy abiertas." Página/12 Cultura y Espectáculo. 21 June 2011. http://www.pagina12.com.ar/imprimir/diario/suplementos/espectaculos/4-22058$\underline{2011-06}$

McHale, Brian. Constructing Postmodernism. London: Rutledge, 1992.

---. Postmodernist Fiction. New York and London: Methuen, 1987.

Millar, Michael. Spaces of Representation. The Struggle for Social Justice in Postwar 
Guatemala. NY: Peter Lang. 2005.

Menton, Seymour. La nueva novella históricade la América latina. 1979-1992. Mexico D.F.: Dondo de Cultura Económica, 1993.

Mondargón Amelia. Cambios estéticos y nuevos proyectos culturales en Centroamérica. Washington D.C.: Literal Books, 1993.

Narcejac, Thomas. Una máquina de leer: la novela policial. Trad. Jorge Ferrero. México, D.F.: Fondo de Cultura Económica, 1986.

Ortiz Wallner, Alexandra. "Espacios asediados. (Re)presentaciones de la violencia y del espacio en novelas centroamericanas de posguerra" Thesis. Universdiad de Costa Rica, 2004. Print.

---. "Literatura y violencia. Para una lectura de Horacio Castellanos Moya." Centroamericana 12 (2007). 85-100. Print.

--. "Narrativas centroamericanas de posguerra: problemas de la constitución de una category de periodización literaria.” Iberoamericana. 5.19 (2005) 135-147. Print.

---. "Trazar un itinerario de lectura: (des)figuraciones de la violencia en una novela guatemalteca." InterSedes. 4.6 (2004) 187-212. Print.

Parkman, Patric. Nonviolent Insurrection in El Salvador: The Fall of Maximiliano Hernández Martínez. Tuscon: U. of Arizona Press, 1988

Perez Brignoli, Hector. Historia general de Centroamérica. De la posguerra a la crisis (1945-1979). Vol. 5. Madrid: Ediciones Siruela, 1993.

Pratt, Mary Louise. "Globalización, desmodernización y el retorno de los monstrous." Globalización y diversidad cultural: Una mirada desde América Latina. Ed. Ramon Pajuelo and Pablo Sandoval. Lima: Instituto de Estudios Peruanos, 2004. $399-415$.

Pulgarín, Amalia. Metaficción historiográfica: La novella histórica en la narrative hispánica posmodernista. Madrid: Editorial Fundamentos, 1995.

Ramirez, Sergio. Balcanes y volcanes. Introducción al proceso cultural centroamericano. Managua: Editorial Nueva Nicaragua. 1983.

---. Castigo divino. Madrid: Mondadori, 1988.

---. El cielo llora por mí. Mexico: Alfaguara, 2008. 
---. Margarita está linda la mar. Madrid: Grupo Santillana de Ediciones/Afaguara, 1998.

Richard, Nelly. La insubornidación de los signos: Cambios politicos, transformaciones culturales y poética de la crisis. Santiago: Cuarto Propio, 1994.

Robinson, William. Transnational Conflicts: Central America Social Change, and Globalization. New York: Verso, 2003.

Rodas, Isabel and Esquit Edgar. Élite ladina, vanguardia indígena de la intolerancia a la violencia, Patzicía 1944. Guatemala: CAUDAL S.A, 1997.

Rodriguez Joulia, Carlos. La Novela de Intriga. Madrid: Editorial Asociación Nacional de Bibliotecarios, Archiveros y Arqueologos, 1970.

Rojas, Margarita. La ciudad y la noche. San José: Ediciones Farben, 2006.

Ríos Torres, Ricardo Arturo. "El Desenterrador, por Ricardo Arturo Ríos." Blog de Panamapoesia.com (2013). http://panamapoesia.blogspot.com/2013/01/el-desenterrador-por-ricardoarturo.html

Sabino, Carlos. Guatemala, la Historia Silenciada (1944-1989). Vol I. Mexico. D.F.: Fondo de Cultura Económica, 2007.

Sim, Suart. "Postmodernism and Philosophy." The Icon Critical Dictionary of Postmodern Thought. Ed. Sturat Sim. London: Icon Books, 1998.

Sklodowska, Elzbieta. "Spanish American Testimonial Novel: Some Afterthoughts." The Real Thing: Testimonial Discourse in Latin America. Ed. Georg Gugelberger. Ruham: Duke UP, 1996. 84-100.

---. Testimonio Hispanoamericano: Historia, teoría, poética. New York: Langa, 1992.

---. "Testimonio mediatizado: ¿Ventriloquia o heteroglossia? (Barnet, et al.).” Revista de Crítica Literaria Latinoamericana. 38 (1993): 81-90.

---. Transgresión párodica de la forma policial, La paroida en la nueva novella hispanoamericana (1960-1985). Amsterdan and Philadelphia: John Benjamins Publishing Company, 1991.

Sodré, Muñiz. Socieada, cultura y violencia. Bogota: Grupo Editorial Norma, 2001.

Spanos, William V. The Detective and the Boundary: Some Notes on the Postmodern 
Literary Imagination. Durham: Duke University P, 1972.

Spencer, Lloyd. "Postmodernism, Modernity and the Tradition of Dissent." The Icon Critical Dictionary of Postmodern Thought. Ed. Sturat Sim. London: Icon Books, 1998.

Swanson, Philip. The New Novel in Latin America. Politics and Popular Culture after the Boom. Manchester: Manchester Up, 1995.

Tadie, Jean-Yves. La Novela de Aventuras. Mexico D.F.: Editorial Fondo de Cultura Económica, 1989.

Tani, Stefano. The Dommed Detective. Carbondale: Southern Illinois University P., 1984.

Todorov, Tzvetan. The Typology of Detective Fiction. Oxford: Blackwell, 1977.

Torres-Rivas, Edelberto. Historia general de Centroamérica. Historia inmediata (19791991). Vol. VI. Madrid: Ediciones Siruela:1993.

Toynbee, Arnold. A Study of History. London: Oxford University Press, 1954.

Vasquez de Parga, Salvador. Los mitos de la novela criminal. Barcelona: Planeta, 1981

Vilas, Carlos. Between Earthquakes and Vocanoes: Market, State, and the Revolutions in Central America. Trans. Ted Kuster. New York: Monthly Rev. P, 1995.

Volek, Emil. Literatura hispanoamericana entre la modernidad y la postmodernidad. Bogota: Unalcol, 1994.

Yúdice, George. "Postmodernity and Transnational Capitalism in Latin America." On Edge: The Crisis of Contemporary Latin American Culture. Ed. Yudice et al. Minneapolis and London: $U$ of Minnesota P, 1992. 1-28.

Waugh, Patricia. The Theory and Practice of Self-Conscious Fiction. Georgetown: Routledge, Chapman \& Hall, 1984.

Wieser, Doris. "Nos hubiéramos matado, si nos hubiéramos encontrado: entrevista a Horacio Castellanos Moya." HeLix 3 (2010). www.helix.unilhd.de

Williams, Raymond L. The Posmodern Novel in Latin America. Politics, Culture and The Crisis of Truth. NY: St. Martin's Press, and London: Macmillan, 1995. 
VITA

\section{GAEL GUZMAN-MEDRANO}

PLACE OF BIRTH: Jinotepe, Carazo. Nicaragua

WORK EXPERIENCE:

Georgia College and State University, Milledgeville, Georgia (Aug. 2010-May 2013)

Spanish Lecturer

Nova Southeastern University, Fort-Lauderdale, Florida (Jan. 2006 - May 2010)

Associate Lecturer / Visiting Professor / Adjunct Professor

Miami Dade College, Miami-Dade, Florida (May 2003 - Aug. 2007)

Adjunct Professor of ESL and Spanish / ESL and Spanish Laboratory Instructor

University of Central Florida, Orlando, Florida (Jan. 2001 - May 2002)

Graduate Teaching Assistant

EDUCATION:

2004-Presente

2001- 2002

1996-1998

1994-1996
Florida International University. Miami, Florida

Spanish Ph.D. Doctoral Candidate

University of Central Florida. Orlando, Florida

Masters of Arts in Spanish

Barry University. Miami Shores, Florida

Bachelors of Arts with a Major in Spanish and a Certification in English/Spanish Translation and Interpretation

Miami Dade Community College, Miami, Florida

Associate of Arts Degree in Psychology

PROFESSIONAL AFILIATIONS:

Modern Language Association, Member

American Council on the Teaching of Foreign Languages, Member

Delta Epsilon Iota (Academic Honor Society), Member

Sigma Delta Pi (National Hispanic Society), Member

Alpha Mu Gamma (National Foreign Language Honor Society), Member

Institute of Hispanic Culture, Miami-Dade, Florida; Honorable Member

Spanish Graduate Student Association at UCF, President (2001-2002)

AWARDS RECEIVED:

2013 Faculty Development Grant, Dept. of Modern Language and Cultures, GCSU

2012 Travel Grant, CLACS, Indiana University

2012 Travel Grant, CTEL, Georgia College \& State University

2011 High Impact Pedagogy, Mini-Grant, CTEL-Georgia College \& State University

2002 Graduate Assistantship, University of Central Florida

1997 Barry University Presidential Scholarship, honor student scholarship

1996 Honor's Student Award from the Psychology Department, MDCC 


\section{MASTER'S THESIS:}

A cercamiento al sistema poético de José Lezama Lima a partir de La expresión americana: un discurso de la especificidad de la cultura de America Latina - Thesis Project defended as part of the requirements for the Masters Degree. University of Central Florida, April, 2002

\section{PUBLICATIONS AND CONFERENCES:}

"Real Historical Settings in a High Impact Role Playing Pedagogy for the Language Classroom" - International Conference on Language for Specific Purposes Teaching and Specialized Translation Skills Training in Higher Education, Peoples' Friendship University of Russia, Moscow, Russia; April, 2013

"The Contemporary Central American Noir Novel: A fiction with Multiple Signs of Social Changes" - Center for Latin American and Caribbean Studies (CLACS) at Indiana University, Indiana University, Bloomington; April, 2012

"El cielo llora por mí: una novela nicaragüense para las nuevas prácticas de la crítica literaria y los estudios culturales" - II Congreso Internacional sobre el Caribe: Cartografías de Género(s), Yo Soy El Otro Asociación Cultural, Madrid, Spain; March, 2012

"Lo obtuso en La mujer habitada de Gioconda Belli; representación paralingüística o textualización de un fragmento histórico nicaragüense." - 1st Annual Inkanations International Conference; Universidad Nacional Mayor de San Marcos, Lima, Perú; August, 2008

"El mito de la melancolía y la construcción de una archaeutopía en Visión de Anáhuac de Alfonso Reyes." - 7th Annual SAGA Colloquium, University of Central Florida; March, 2007

"La 'identidad latina', fusión cultural postmoderna, en How the García Girls Lost Their Accent de Julia Álvarez" - "Hyphen-Nation" The Space of the Hyphen in Contemporary Culture Graduate Students Conference, University of Miami; March, 2006

"Ensayo Sobre la Obra de Juan Rulfo", Literary Article, published in Huella sin fronteras, Revista Literaria de Circulo de Lectura. U.S.M.A. Vol. 8, 2001

"El orden divino, teoría política en la sociedad medieval, y la figura del Cid como máximo ejemplo de éste en la literature española" - 2nd Annual SAGA Colloquium, University of Central Florida; April, 2002

"Estudio acerca del Dialogo sobre la dignidad del hombre como reflejo de la ideología humanista del renacimento" - 1st Annual SAGA Colloquium, University of Central Florida; April, 2001 